$$
\text { UNIVERSIDADE DE SÃO PAULO }
$$

FACULDADE DE ECONOMIA, ADMINISTRAÇÃO E CONTABILIDADE DEPARTAMENTO DE CONTABILIDADE E ATUÁRIA PROGRAMA DE PÓS-GRADUAÇÃO EM CIÊNCIAS CONTÁBEIS

A DEMONSTRAÇÃO DO VALOR ADICIONADO COMO INSTRUMENTO DE TRANSPARÊNCIA NAS ENTIDADES DO TERCEIRO SETOR

Cristiane Nagai

Orientador: Prof. Dr. Ariovaldo dos Santos 
Prof. Dr. João Grandino Rodas Reitor da Universidade de São Paulo

Prof. Dr. Reinaldo Guerreiro

Diretor da Faculdade de Economia, Administração e Contabilidade

Prof. Dr. Edgard Bruno Cornachione Junior Chefe do Departamento de Contabilidade e Atuária

Prof. Dr. Luís Eduardo Afonso

Coordenador do Programa de Pós-Graduação em Contabilidade 


\title{
CRISTIANE NAGAI
}

\section{A DEMONSTRAÇÃO DO VALOR ADICIONADO COMO INSTRUMENTO DE TRANSPARÊNCIA NAS ENTIDADES DO TERCEIRO SETOR}

\author{
Dissertação apresentada ao Programa de Pós- \\ Graduação em Controladoria e Contabilidade \\ da Faculdade de Economia, Administração e \\ Contabilidade da Universidade de São Paulo, \\ para obtenção do título de Mestre em Ciências.
}

Orientador: Prof. Dr. Ariovaldo dos Santos

\author{
Versão Corrigida
}

(versão original disponível na Faculdade de Economia, Administração e Contabilidade) 
FICHA CATALOGRÁFICA

Elaborada pela Seção de Processamento Técnico do SBD/FEA/USP

\section{Nagai, Cristiane}

A demonstração do valor adicionado como instrumento de transparência nas entidades do terceiro setor / Cristiane Nagai. - São Paulo, 2012.

$100 \mathrm{p}$.

Dissertação (Mestrado) - Universidade de São Paulo, 2012. Orientador: Ariovaldo dos Santos.

1. Demonstração financeira 2. Valor adicionado 3. Terceiro setor 4. Responsabilidade social I. Universidade de São Paulo. Faculdade de Economia, Administração e Contabilidade. II. Título.

$$
\text { CDD }-657.3
$$


Ao Daniel,

cuja ausência será sempre sentida. 
Para muitos, a conclusão de um curso de Mestrado, além de tarefa árdua, que exige esforço, dedicação e perseverança é definida como uma jornada ou uma etapa importante na vida do estudante. Para mim, a expectativa de concluir o mestrado tendo que aplicar esforço, dedicação e perseverança motivou meu desejo de existir e continuar. Agradeço a Deus, por me fazer voltar a acreditar.

Ao professor Dr. Ariovaldo dos Santos, por sua compreensão, paciência, confiança e orientação, mesmo diante de minha aparente displicência no desenvolvimento deste trabalho, minha sincera e profunda gratidão. Aos professores doutores Bruno Meirelles Salloti e Maisa de Souza Ribeiro, pelas importantíssimas contribuições na banca de qualificação, essenciais para o desenvolvimento desta pesquisa.

A todo o corpo docente do Departamento de Ciências Contábeis, pelos conhecimentos transmitidos, em especial ao professor doutor Eliseu Martins que com simplicidade ímpar, conduz os espetáculos que são suas aulas. Foi uma honra poder ouvi-lo.

Aos funcionários das secretarias da pós-graduação, da biblioteca da FEA e do departamento, sempre prestativos, gentis e acolhedores.

Ao professor Hildebrando Hilton de Souza Oliveira, a quem reservo enorme respeito, carinho e gratidão, por todos os ensinamentos e conversas que me impulsionam a procurar ser melhor como profissional e como pessoa, e pela confiança, contribuição e apoio para a realização de um sonho. Aos professores e hoje, queridos amigos, Fernanda M. F. Frossard, Maria José Teixeira, Artur F. Bueno e Wilson J. Correa pelo apoio e incentivo. Ao professor Wolney José dos Anjos por sua presença constante e pelas tantas contribuições no desenvolvimento das tarefas do curso.

Aos amigos (doutorandos e mestrandos) Alexandre Gonzales, Renata Turola Takamatsu, Juliana Ventura Amaral, Sheila Melo, Carlos Eduardo Braz Valeriano, George André Willrich Sales, Rafael Sasso, Aziz Beiruth, Fabio Calhau e Anderson Pinzan, pelo companheirismo e por todos os momentos que compartilhamos. À Ana Paula Capuano da Cruz, Alex Mussoi, Carlos Henrique do Carmo, Esmael Almeida Machado e Daniel Nogueira, pela experiência e conhecimentos compartilhados.

À minha família, pelo apoio incondicional de sempre, captado mesmo no silêncio. 
"Não é a consciência do homem que lhe determina o ser, mas, ao contrário, o seu ser social que lhe determina a consciência". 


\section{RESUMO}

A presente pesquisa foi desenvolvida com o objetivo de analisar qual a maneira mais adequada de evidenciar na Demonstração do Valor Adicionado, as receitas das entidades do terceiro setor diante das diversas fontes disponíveis para captá-las. Subsidiariamente e com base na conclusão da tese de doutorado de Fregonesi (2009) de que os investimentos socioambientais feitos pelas empresas às entidades sem fins lucrativos são, em determinadas situações, distribuição do valor adicionado, o presente estudo objetivou analisar o impacto da referida conclusão na DVA das entidades sem fins lucrativos, mais especificamente, das fundações e institutos empresariais e suas eventuais implicações na utilidade da DVA como instrumento auxiliar para o cálculo da participação deste setor no produto nacional. As entidades utilizadas como exemplos são as associadas ao Grupo de Institutos, Fundações e Empresas (GIFE) sendo descartadas as que não possuíam a expressão "Instituto" ou "Fundação" em suas denominações sociais e entidades que não publicaram suas demonstrações contábeis de 2010 com notas explicativas em suas páginas eletrônicas ou no Diário Oficial Empresarial de São Paulo entre o período de janeiro a abril de 2011. Foram incluídas na análise a Fundação Instituto de Pesquisas Contábeis, Atuariais e Financeiras (FIPECAFI) e a Fundação Salvador Arena em função de sua notoriedade e para enriquecer a compreensão do modus operandi dessas entidades no processo de captação de recursos. Os resultados sugerem que nem todas as entidades do terceiro setor geram valor adicionado, assumindo, em alguns casos, o papel de meras gestoras de recursos advindos de suas mantenedoras, que buscam dar forma à sua responsabilidade social. Neste caso, por haver redistribuição secundária de renda, o produto nacional não computaria a participação dessas entidades.

Palavras-chave: DVA, Terceiro Setor, PIB, Investimentos Socioambientais. 


\begin{abstract}
This research was developed in order to analyze what the most appropriate way to highlight the Value Added Statement, revenues from the third sector entities on the various sources available to capture them. Secondly and based on the conclusion of the doctoral thesis of Fregonesi (2009) that social and environmental investments made by companies to nonprofits are, in certain situations, the distribution of value added, this study aimed to analyze the impact of this conclusion at VAS of nonprofits, more specifically, enterprise foundations and institutes and its possible implications on the usefulness of the VAS as an aid for calculating the contribution of this sector in the national gross product. The entities used as examples are associated with the Group of Institutes, Foundations and Enterprises (GIFE) being discarded those that did not have the term "Institute" or "Foundation" in their names or entities that did not publish its financial statements with notes, 2010 explanatory in its pages in the Official Gazette or Electronic Business São Paulo between January and April 2011. Were included in the analysis the Research Institute of Accounting, Actuarial and Financial (FIPECAFI) and Salvador Arena Foundation because of its reputation and to enrich the understanding of the modus operandi of these entities in the process of fundraising. The results suggest that not all third sector entities generate added value, assuming in some cases, the role of mere management of resources from their keepers, who seek to shape their social responsibility. In this case, because there is secondary redistribution of income, national gross product does not compute the participation of these entities.
\end{abstract}

Keywords: VAS, Third Sector, National Gross Product, Corporate Social Responsability. 


\section{SUMÁRIO}

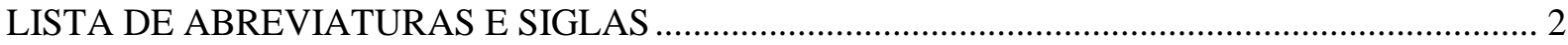

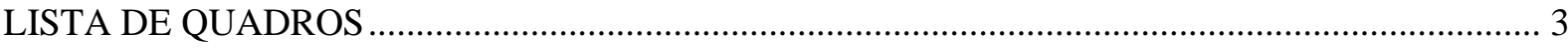

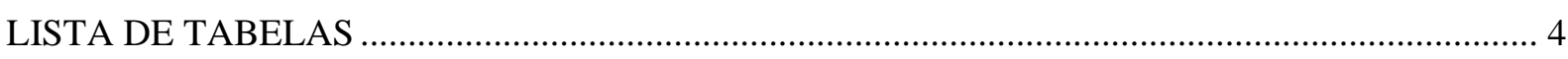

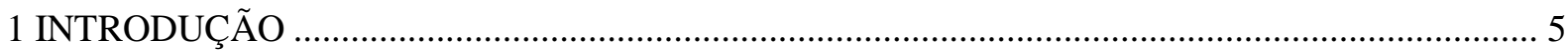

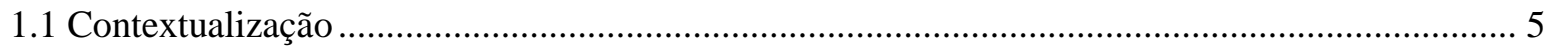

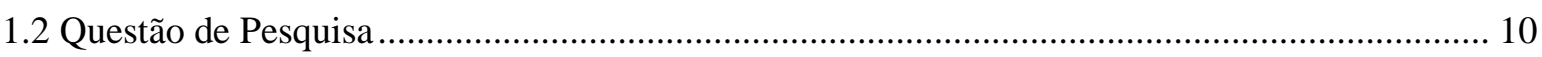

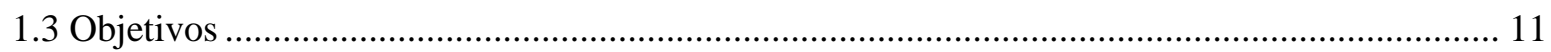

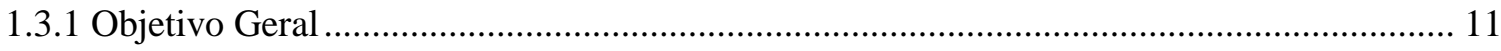

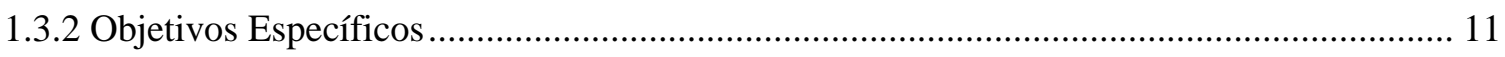

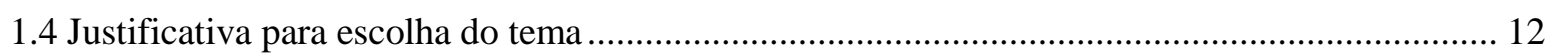

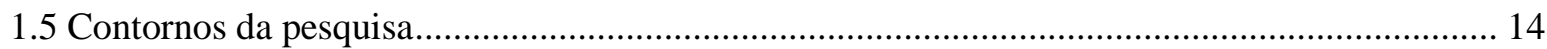

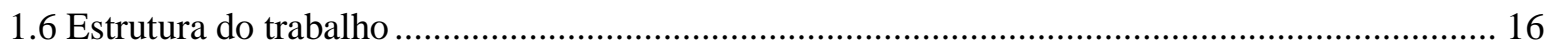

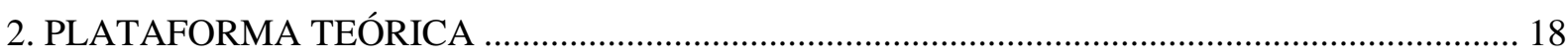

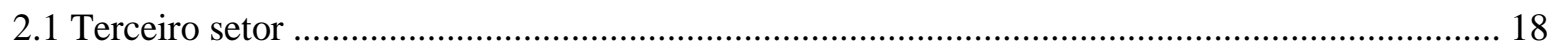

2.1.1 Breve histórico do desenvolvimento do terceiro setor no Brasil.......................................... 18

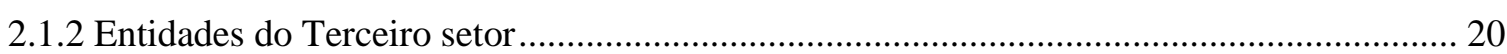

2.1.3 A importância da prestação de contas para o terceiro setor ................................................... 29

2.1.4 Legislação contábil aplicável às entidades do Terceiro setor.................................................... 32

2.2 Balanço Social e Demonstração do Valor Adicionado ................................................................ 33

2.2.1 A contribuição da DVA para o cálculo do PIB e a participação do terceiro setor ................ 40

3 EVIDENCIAÇÃO DOS RECURSOS DAS ENTIDADES DO TERCEIRO SETOR NA

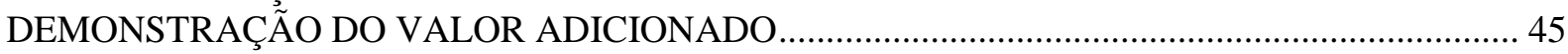

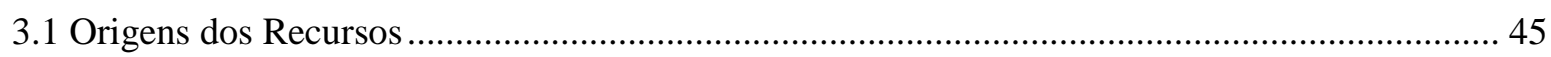

3.2 Os investimentos socioambientais na DVA dos investidores conforme tese de Fregonesi ........ 47

3.3 A estrutura da DVA conforme modelo do CPC e a composição do valor adicionado das

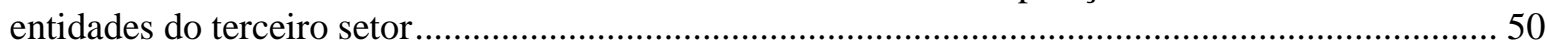

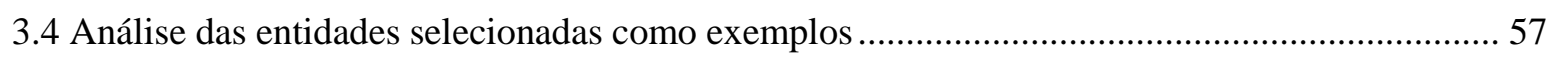

3.4.1 GRUPO 1 - Fundação Instituto de Pesquisas Contábeis, Atuariais e Financeiras (Fipecafi) 58

3.4.2 GRUPO 2 - Fundação Bradesco, Fundação Salvador Arena, Fundação Bunge, Instituto

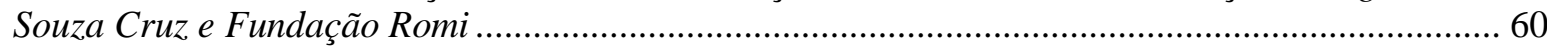

3.4.3 GRUPO 3 - Instituto Ayrton Senna, Fundação Abrinq pelos direitos da criança e do

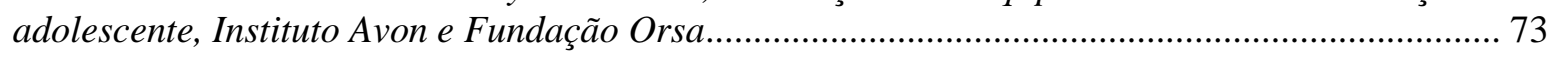

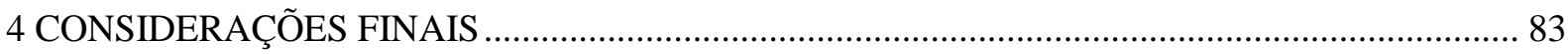

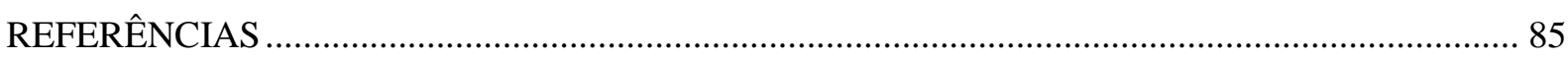

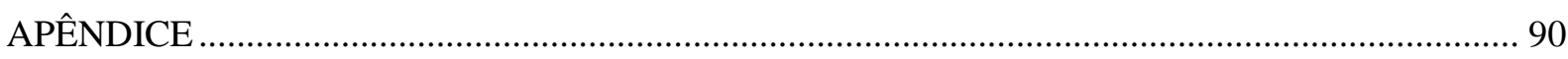

APÊNDICE 1 - Entidades associadas ao GIFE no período de 2009 e 2010 ............................................ 90 


\section{LISTA DE ABREVIATURAS E SIGLAS}

ABONG: Associação Brasileira de Organizações Não Governamentais CEBAS: Certificação de Entidades Beneficentes de Assistência Social CFC: Conselho Federal de Contabilidade

CNAS - Conselho Nacional de Assistência Social

CPC: Comitê de Pronunciamentos Contábeis

CPI: Comissão Parlamentar de Inquérito

CVM: Comissão de Valores Mobiliários

DOAR: Demonstração das Origens e Aplicações de Recursos

DVA: Demonstração do Valor Adicionado

ESFL: Entidades sem fins lucrativos

FIPECAFI: Fundação Instituto de Pesquisas Contábeis, Atuariais e Financeiras

GIFE: Grupo de Institutos, Fundações e Empresas

IBGE: Instituto Brasileiro de Geografia e Estatística

NBC T: Norma Brasileira de Contabilidade Técnica

OAB: Ordem dos Advogados do Brasil

ONG: Organizações Não Governamentais

ONU: Organização das Nações Unidas

OSCIP: Organização da Sociedade Civil de Interesse Público

PIB: Produto Interno Bruto 


\section{LISTA DE QUADROS}

Quadro 1 - Entidades associadas ao GIFE selecionadas como exemplos ............................................ 16

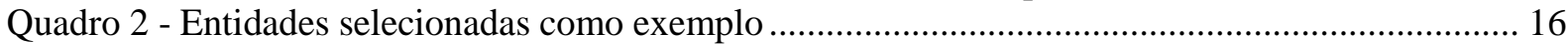

Quadro 3 - Diferenças entre Associação e Fundação............................................................................. 21

Quadro 4 - Resumo dos tipos de certificação/titulação das ESFL e respectivos benefícios .................. 28

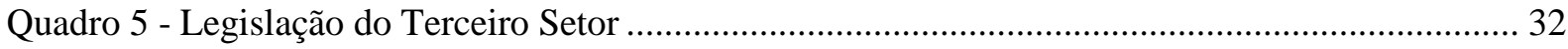

Quadro 6 - Tabela de Valor Econômico Gerado e Distribuído (EVG\&D) do GRI ............................... 35

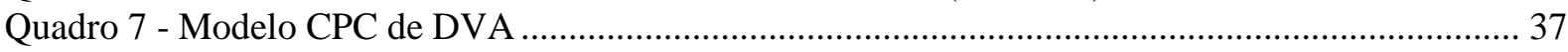

Quadro 8 - Estrutura da Ficha de Origem e Aplicação de Recursos - DIPJ 2012 ................................. 43 


\section{LISTA DE TABELAS}

Tabela 1 - Faixas de ano de fundação e unidades locais das Fundações Privadas e Associações sem Fins Lucrativos - Brasil - 2005 .................................................................................. 19 


\section{INTRODUÇÃO}

\subsection{Contextualização}

Admitindo o pressuposto de que a sociedade é dividida em setores, a ordem sociopolítica até recentemente era composta de um lado pelo Estado - o primeiro setor - e de outro pelo Mercado - o segundo setor.

O primeiro setor, apesar de ser responsável por garantir os direitos sociais elencados no art. $6^{\circ}$ da Constituição Federal de 1988, tais como educação, saúde e assistência aos desamparados, não tem condições de suprir por si só as demandas da sociedade por meio de suas políticas públicas. Conforme cita Tachizawa (2002),

O setor governamental, de serviços públicos, dado seu extraordinário crescimento, influenciou a estagnação da capacidade do Estado em fazer frente a suas tradicionais atividades-fins, como saúde, segurança, saneamento básico, educação, transportes, entre outras. (TACHIZAWA, 2002, p. $52)$.

Diante da necessidade de se promover o desenvolvimento social, nem sempre alcançado de modo eficaz pelo Estado e do relevante volume de recursos humanos e materiais disponibilizados, tanto por pessoas jurídicas em busca de incremento de sua responsabilidade social como por pessoas físicas, suficientes para mobilizar e possibilitar iniciativas voltadas para tal promoção, vislumbra-se a existência de um terceiro setor composto por entidades de interesse social, no qual se inserem as sociedades sem fins lucrativos, que, apesar das diversas denominações que assumem (organizações não governamentais, organizações da sociedade civil de interesse público, fundações, institutos, organizações sociais, dentre outras), são juridicamente constituídas sob a forma de associações civis ou fundações de direito privado conforme artigo 44 do novo Código Civil.

Artigo 44, CC: "São pessoas jurídicas de direito privado:

I - as associações;

II - as sociedades;

III - as fundações; 


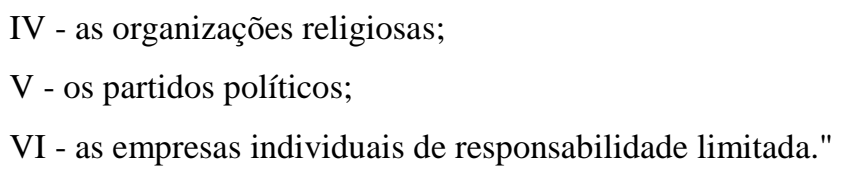

Paes (2006, p. 122) explica que o terceiro setor é composto por organizações de natureza privada, sem fito de lucro, que se dedicam à consecução de objetivos sociais ou públicos, embora não seja integrante da Administração Estatal. Conceitualmente,

\footnotetext{
“é o conjunto de organismos, organizações ou instituições sem fins lucrativos dotados de autonomia e administração própria que apresentam como função e objetivo principal atuar voluntariamente junto à sociedade civil visando ao seu aperfeiçoamento" (PAES, 2006, p.122).
}

Embora não se observe no Brasil um marco regulatório do terceiro setor e sim legislação esparsa sobre o assunto, submetendo suas entidades componentes a certa insegurança jurídica, o ordenamento jurídico interno vigente no Brasil admite que organizações do terceiro setor ou organizações não governamentais (ONGs) são entidades de interesse social, sem fins lucrativos, tais como as associações e as fundações de direito privado, com autonomia e administração própria, cujo objetivo é o atendimento de alguma necessidade social ou a defesa de direitos difusos ou emergentes (PAES, 2006, p. 123).

De modo que se torne possível a consecução dos objetivos dessas entidades, qual seja, a de promover o bem-estar social, são necessárias fontes de recursos para movimentá-las. As origens desses recursos que as sustentam podem ser diversos, como, por exemplo, por meio de concessão de verbas públicas, doações de pessoas físicas ou jurídicas ou por meio de remuneração proveniente de suas atividades mercantis.

Ainda que as entidades que compõem o terceiro setor desenvolvam atividades sem o fito de lucro, não implica dizer que estão desoneradas de obrigações relacionadas à prestação de contas no âmbito contábil. Ao contrário, pela natureza do aporte de recursos das entidades do terceiro setor e por gozarem de certas imunidades e isenções tributárias concedidas pelo Estado, suas informações contábeis devem guardar elevado nível de transparência.

As imunidades e isenções concedidas pelo poder público estão condicionadas à obtenção de determinadas titulações e certificações por parte das entidades. As entidades beneficentes que 
atuam nas categorias tradicionais - saúde, educação e assistência social -, para manterem tal titulação, por exemplo, possuem a obrigatoriedade de aplicar parte de suas receitas em gratuidades e comprovar tal destinação.

No rol das obrigações dessas entidades qualificadas como beneficentes figuram a não remuneração de seus dirigentes, prestações de contas ao Conselho Nacional de Assistência Social (CNAS), manutenção da transparência na aplicação de recursos públicos recebidos e, dependendo do volume de receitas auferidas ${ }^{1}$, submissão de suas demonstrações contábeis a auditores independentes (BARBOSA; OLIVEIRA, 2011, p. 150).

Em termos de legislação e prática contábil específica de entidades sem fins lucrativos, Olak e Nascimento (2010, p. 52) mencionam que o Brasil encontra-se em fase embrionária. O Conselho Federal de Contabilidade (CFC) passou a normatizar sobre o setor a partir de 1999 editando as normas técnicas NBC T 10.4 - Fundações aprovada pela Resolução CFC n. 837/99, NBC T 10.18 - Entidades sindicais e associações de classe aprovada pela Resolução CFC n. 838/99, alterada pela Resolução CFC n. 852/99 e NBC T 10.19 - Entidades sem finalidade de lucros aprovada pela Resolução CFC n. 877/00, alterada pelas Resoluções CFC n. $926 / 01$ e n. $966 / 03$.

De acordo com as normas citadas as entidades devem elaborar o conjunto de demonstrações contábeis determinadas pela NBC T 3, quais sejam, Balanço Patrimonial, Demonstração do Superávit do Exercício, Demonstrações do Patrimônio Social, Demonstração das Origens e Aplicações de Recursos e Notas Explicativas onde devem constar o resumo das principais práticas contábeis, os critérios de apuração das receitas, despesas, gratuidades, doações, subvenções e aplicações de recursos e os critérios de mensuração dos gastos e despesas.

A partir da vigência da Lei $n^{\circ} 11.638 / 07$ que alterou sobremaneira a Lei $n^{\circ}$ 6.404/76, a Demonstração das Origens e Aplicações de Recursos (DOAR) deixou de ser obrigatória, sendo substituída pela Demonstração do Fluxo de Caixa e, para as companhias abertas, foi imposta a obrigatoriedade de elaboração da Demonstração do Valor Adicionado (DVA).

\footnotetext{
${ }^{1}$ No caso de microempresa, receita bruta igual ou inferior a $\mathrm{R} \$ 360.000,00$ e no caso da empresa de pequeno porte, receita bruta superior a $\mathrm{R} \$ 360.000,00$ e igual ou inferior a $\mathrm{R} \$ 3.600 .000,00$, conforme Lei Complementar $\mathrm{n}^{\circ} 139$ de 2011.
} 
A DVA é um instrumento complementar na análise da situação econômico-financeira das empresas. Além de demonstrar a formação de riqueza criada pelas entidades com fins de lucro, evidencia como é distribuída aos diversos fatores produtivos.

Não obstante sua obrigatoriedade ter surgido com a Lei $\mathrm{n}^{\circ}$ 11.638/07, muitas empresas já publicavam a DVA em função da busca dessas empresas por uma classificação no anuário "Melhores e Maiores" da Revista EXAME (Editora Abril) que instituiu, a partir de 1998, a DVA como um dos quesitos objetos de pontuação para tal classificação (SANTOS; CARVALHO, 1997, p. 132).

A DVA quando estruturada pela Fundação Instituto de Pesquisas Contábeis, Atuariais e Financeiras (Fipecafi), considerava ramos específicos de negócio: empresas prestadoras de serviços, comerciais e industriais.. Atualmente, a DVA é objeto de Pronunciamento Técnico específico (CPC 09 - Demonstração do Valor Adicionado) emitido pelo Comitê de Pronunciamentos Contábeis (CPC), organismo brasileiro responsável pela emissão de normas contábeis convergidas às internacionais.

Além de "compreender todo um conjunto de informações de natureza econômica, que visa demonstrar o valor da riqueza gerada pela empresa e sua distribuição com os elementos que contribuíram para sua geração" (De Luca et al., 2009, p. 22), a DVA constitui importante ferramenta de auxílio no cálculo do PIB dado que sua estrutura, conforme explica Iudícibus (1990, p. 4), assemelha-se ao esquema de contas de renda nacional. Isso implicaria dizer que, somadas todas as demonstrações de valor adicionado elaboradas por todas as atividades econômicas desenvolvidas no país, excluídas as duplas contagens, vislumbraríamos o valor do PIB.

As maiores fontes de financiamento do terceiro setor são as doações e subvenções recebidas de entes públicos e privados. Considerando sua atividade de promoção do desenvolvimento social, a fim de que haja continuidade de suas atividades financiadas por entidades do governo ou mesmo de capital privado, é necessário que suas demonstrações contábeis - instrumento de acesso aos investidores neste setor, proporcionem transparência de informações. Em outras palavras, deve ser possível ao investidor além de conhecer o resultado de suas doações e subvenções, mensurar o quanto de sua contribuição está sendo convertida em desenvolvimento social de fato. 
Considerando que as entidades sem fins lucrativos elaboram suas demonstrações financeiras adaptando àquelas das sociedades com fins lucrativos, é uma questão de tempo para que se passe a observar entidades elaborando e divulgando, além da Demonstração do Fluxo de Caixa, quiçá a Demonstração do Valor Adicionado, o que seria de grande serventia para o incremento da credibilidade das entidades sem fins de lucro uma vez que a DVA auxiliaria não só na evidenciação das receitas arrecadadas, como também na sua conversão/distribuição em gratuidade, requisito essencial para a manutenção de determinadas titulações e certificações.

A ideia de se valer da DVA como um instrumento de transparência para as entidades do terceiro setor apóia-se na afirmação de Santos (2007) de que a demonstração contábil em referência "é a forma mais competente criada pela Contabilidade para auxiliar na medição e demonstração da capacidade de geração, bem como distribuição da riqueza de uma entidade" (SANTOS, 2007, p. 37).

Além disso, e para maior incentivo da elaboração da DVA pelas entidades sem fins lucrativos, na última revisão das contas nacionais realizada em 2007 pelo Instituto Brasileiro de Geografia e Estatística (IBGE) o terceiro setor foi reconhecido como uma esfera de atividade com características próprias, distinguindo-se do Estado e do conjunto das organizações do setor privado.

$\mathrm{Na}$ série Relatórios Metodológicos (IBGE, 2008) o IBGE divulga as metodologias empregadas nas diversas fases do planejamento e execução de suas pesquisas. O terceiro setor, denominado instituições sem fins de lucro a serviço das famílias, sob a ótica do IBGE

“[...] são as entidades jurídicas ou sociais criadas com o objetivo de produzir bens ou serviços para as famílias, cujo estatuto não lhes permite ser uma fonte de rendimento, lucro ou outro ganho financeiro para as unidades que as criam, controlam ou financiam" (IBGE, 2008, p. 85).

De acordo com Merege (2009, p. 10), a importância de se calcular separadamente o valor movimentado pelo terceiro setor foi reconhecido em 2002 pelo departamento de estatística da 
Organização das Nações Unidas (ONU) e o Brasil é um dos poucos países ${ }^{2}$ que incluem esse setor no cálculo do PIB.

No que se refere à DVA como instrumento de análise da geração e distribuição de riqueza das entidades sem fins de lucro, o presente estudo objetiva investigar se as diferentes fontes de recursos obtidos por essas entidades implicam em diferentes modos de evidenciá-las na referida demonstração, impactando assim, a sua proposta de auxiliar na medição da participação das entidades sem fins de lucro no PIB.

Neste ponto do estudo, suscitou-se a tese de doutoramento de Fregonesi (2009, p. 159) que investigou, à luz dos conceitos econômicos, quais seriam as condições para os investimentos socioambientais feitos pelas empresas em busca de incremento de sua responsabilidade social serem considerados distribuição do valor adicionado na DVA.

Fregonesi (2009) conclui que os investimentos socioambientais caracterizados como doações não podem ser considerados insumos do processo produtivo porque não há recebimento de produto ou serviço em contrapartida do recurso. Também não podem ser considerados como remuneração dos fatores de produção porque não se configura aluguel do serviço do capital, terra ou trabalho. Portanto, as doações deveriam ser classificadas como redistribuição da renda gerada e aparecer na DVA, no grupo 7 - Distribuição do Valor Adicionado.

Se por um lado a autora conclui que as doações feitas por pessoas jurídicas seriam melhor classificadas na DVA como distribuição de valor adicionado, por consequência, as entidades sem fins lucrativos que recebem essas doações deveriam evidenciá-las em suas DVA no grupo 6 - Valor Adicionado recebido em transferência?

\subsection{Questão de Pesquisa}

Dada a importância da prestação de contas para as entidades sem fins lucrativos e a responsabilidade do meio acadêmico de buscar mecanismos ou levantar questões para o aperfeiçoamento dos já existentes para viabilizar esse processo, no presente estudo serão analisadas as fontes de recursos das entidades do terceiro setor selecionadas como exemplo, e

\footnotetext{
${ }^{2}$ Atualmente os países que incluem o terceiro setor em suas estatísticas econômicas são: Argentina, Austrália, Bélgica, Canadá, República Tcheca, França, Israel, Itália, Quênia, Nova Zelândia, Peru e EUA (Merege, 2009, p. $10)$.
} 
como poderiam ser evidenciadas na Demonstração do Valor Adicionado, visto que são poucas as entidades desse setor que elaboram e divulgam tal demonstração contábil.

A finalidade de se proceder a essa análise é inferir se tal demonstração contábil poderia ser considerada uma boa ferramenta de informação sobre a distribuição do valor adicionado gerado por essas entidades como assim requerem os entes públicos e a sociedade em geral que aplica seus recursos nessas entidades. Ainda, diferentes modos de evidenciação das receitas implicariam em melhores vislumbres acerca da contribuição dessas entidades na composição do PIB?

Desse modo, com o propósito de contribuir para o esclarecimento da presente situaçãoproblema, a questão norteadora da pesquisa é:

\section{"Para melhor contribuição da DVA como instrumento auxiliar no cálculo do PIB, as diversas origens de recursos das entidades de terceiro setor implicariam em diferentes modos de evidenciação na referida demonstração contábil?}

\subsection{Objetivos}

Diante do problema apresentado, o estudo será desenvolvido com o intuito de contribuir para o desenvolvimento da gestão e principalmente da prestação de contas à sociedade das entidades do terceiro setor.

\subsubsection{Objetivo Geral}

Compreender, explicar e descrever quais são as fontes de recursos das entidades do terceiro setor e como poderiam ser evidenciadas na Demonstração do Valor Adicionado para uma melhor contribuição ao cálculo da participação destas entidades no produto nacional.

\subsubsection{Objetivos Específicos}

- Identificar as principais características do terceiro setor.

- Descrever sobre as fontes de recursos das entidades filantrópicas sem fins lucrativos.

- Detectar as origens de recursos das entidades selecionadas como exemplo; 
- Verificar qual é o tratamento e evidenciação das doações recebidas pelas entidades analisadas na Demonstração do Valor Adicionado, dentre aquelas que a elaboram e divulgam.

- Apresentar simulações de DVA para as entidades tomadas como exemplo aplicando as conclusões de Fregonesi (2009).

\subsection{Justificativa para escolha do tema}

Conforme levantamento realizado em 2005 pelo Instituto Brasileiro de Geografia e Estatística (IBGE), em parceria com o Instituto de Pesquisa Econômica Aplicada (Ipea), com a Associação Brasileira de Organizações Não Governamentais (ABONG), e com o Grupo de Institutos, Fundações e Empresas (GIFE), o Brasil possuía até então 8.228 fundações privadas e 329.934 associações sem fins lucrativos perfazendo um universo de 338.162 entidades compondo formalmente o terceiro setor (IBGE, 2005).

De acordo com o estudo, entre essas 338 mil entidades privadas sem fins lucrativos, 35,2\% atuavam na defesa dos direitos e interesses dos cidadãos, $24,8 \%$ eram instituições religiosas e 7,2\% desenvolviam ações de saúde, educação e pesquisa e empregavam 1,7 milhão de pessoas (IBGE, 2005).

A importância do terceiro setor, traduzida pelo número das instituições formais levantadas no estudo do IBGE também é reforçada pela análise dos recursos concedidos pelo poder público. Segundo o governo federal, foram destinados às entidades privadas sem fins lucrativos, em 2010, R\$5,4 bilhões (CGU, 2011).

Em 2007 foi instaurada uma Comissão Parlamentar de Inquérito (CPI) a fim de investigar os repasses de dinheiro público para organizações não governamentais. Com vistas ao relatório final da referida CPI, apesar de não ter sido votado, a presidente Dilma Rousseff determinou, recentemente, por meio do Decreto 7.568/11 que a celebração de convênio ou contrato de repasse com entidades privadas sem fins lucrativos seja precedida de chamamento público visando a seleção de projeto ou entidades, com o intuito de diminuir a margem de acordos que resultem em desvios de finalidade. Além disso, no mesmo decreto consta a proibição do governo de realizar parcerias com entidades privadas sem fins lucrativos que não comprovem 
ter desenvolvido, durante os últimos três anos, atividades referentes à matéria objeto do convênio ou contrato de repasse de recursos públicos (BRASIL, 2011).

Vale ressaltar que, atualmente, não há informações disponíveis no governo sobre o número de organizações não governamentais, em sentido estrito, que recebem recursos públicos ou um cadastro de entidades que não fizeram prestações de contas dos recursos recebidos e que, por isso, não poderiam mais receber transferências. Como forma de sanar essa incongruência, consta no Decreto n. 7.592 de 31 de outubro de 2011 que a Controladoria Geral da União deverá manter esse cadastro (IPEA, 2011).

Não obstante a magnitude de recursos públicos destinados a essas entidades, e assunto que consequentemente desperta o interesse da sociedade, são recentes os estudos relacionados a este setor.

Em 1994, por exemplo, a fim de tornar possível o cumprimento de uma cláusula contratual imposta pelo Banco Mundial para a melhoria do ensino básico na região metropolitana de São Paulo, a Secretaria Estadual de Educação foi obrigada a realizar uma pesquisa para identificar e avaliar as organizações não governamentais que trabalhavam com educação pré-escolar. Isto porque, ficou estabelecido no acordo, cláusula mandatória em que o governo estadual deveria repassar $15 \%$ dos recursos recebidos para organizações não governamentais locais (COELHO, 2008, p. 18).

Nesse sentido, Falconer (1999, p. 2) relata que o campo de estudo do terceiro setor é uma das áreas mais novas e multidisciplinares das Ciências Sociais tanto no Brasil quanto no resto do mundo.

Dias (2008, p. 97) corrobora tal assertiva explicando que os trabalhos acadêmicos produzidos no Brasil com base na terminologia "terceiro setor" começaram a ser produzidos a partir da segunda metade da década de noventa do século passado, sob a ótica, sobretudo, das Ciências Sociais, da Antropologia e da Ciência Política. 
Ao desempenharem atividades na busca pelo bem comum e pelo desenvolvimento sustentável do Brasil, os estudos relacionados ao tema se revestem de relevância e contribuem para a manutenção e desenvolvimento das instituições sem fins lucrativos.

Se às entidades do terceiro setor são impostas obrigações relacionadas à transparência de informações, é na aliança com a Contabilidade que se encontra o meio adequado de se alcançar os mais diversos tipos de usuários de tal informação.

Assim, inicia-se o delineamento de um ponto de contato entre a Contabilidade e sua abordagem sociológica que conforme Iudícibus "é uma abordagem do tipo "bem-estar social" (welfare), no sentido de que os procedimentos contábeis e os relatórios emanados da Contabilidade deveriam atender a finalidades sociais mais amplas" (IUDÍCIBUS, 2006, p. 27).

No entanto, apesar de as entidades do terceiro setor utilizarem, de fato, a Contabilidade para atestar a transparência na destinação dos recursos públicos recebidos para execução de seus fins, a Contabilidade, por sua vez, deve sempre buscar mecanismos que melhorem ainda mais o nível qualitativo da informação que leva aos seus usuários.

É neste sentido que o estudo procura analisar se a Demonstração do Valor Adicionado, inicialmente proposta pela Fipecafi e atualmente objeto de Pronunciamento Técnico emitido pelo Comitê de Pronunciamentos Contábeis - CPC, recomendado pela Comissão de Valores Mobiliários - CVM e pelo Conselho Federal de Contabilidade - CFC, ainda que não tenha sido concebida especificamente para o terceiro setor, poderia melhorar o nível da prestação de contas das atividades das entidades sem fins lucrativos e, a depender da origem de recursos e consequente modo de evidenciação, contribuiria para o refinamento no cálculo de sua participação no PIB.

\subsection{Contornos da pesquisa}

Martins e Theóphilo (2009, p. 22) mencionam que um problema se origina da inquietação, da dúvida, da hesitação, da perplexidade, da curiosidade sobre uma questão não resolvida. Este estudo surge da dúvida sobre a utilidade da Demonstração do Valor Adicionado como 
instrumento contábil auxiliar no cálculo da participação das entidades sem fins lucrativos no PIB, diante das diversas origens de receitas e como atualmente são evidenciadas nesta demonstração e, ainda, se tal demonstração contábil poderia servir às entidades beneficentes em sua obrigação de evidenciar as destinações de parte de suas receitas em gratuidades.

A abordagem utilizada na pesquisa é funcionalista uma vez que envolve análise e avaliação de papéis, funcionamento de organizações, avaliação, expectativas (MARTINS e THEÓPHILO, 2009, p. 42).

As estratégias de pesquisa adotadas para subsidiar os propósitos deste estudo são a bibliográfica e documental. Segundo Martins e Theóphilo (2009, p. 55), a principal diferença entre elas decorre da natureza de suas fontes: enquanto a pesquisa bibliográfica utiliza fontes secundárias tais como livros, jornais e artigos, a pesquisa documental emprega fontes primárias, que ainda não foram objeto de análise ou que ainda podem ser reelaborados de acordo com os propósitos da pesquisa.

Para selecionar as entidades a serem analisadas e que funcionarão como exemplos, foram consideradas aquelas associadas ao Grupo de Institutos, Fundações e Empresas (GIFE), base novembro de 2010, por se tratar da primeira associação da América do Sul a reunir investidores sociais privados e que desde 2001 promove o denominado Censo GIFE com informações sobre origem e volume do capital investido por suas associadas, governança e gestão, estratégias de ação, beneficiários, avaliação e monitoramento da ação social. As entidades associadas e constantes no último Censo GIFE (2009-2010) são as constantes no Anexo 1.

Dentre as 133 associadas do GIFE, foram selecionadas somente aquelas com as expressões "Instituto" e "Fundações". Na sequência, por meio de visita às páginas eletrônicas das entidades selecionadas, refinou-se o número de entidades, sendo selecionadas apenas as que publicam suas demonstrações contábeis na própria página eletrônica ou, na ausência desta, que publicaram suas demonstrações contábeis no Diário Oficial Empresarial de São Paulo no período de janeiro a abril de 2011. Das 133 entidades inicialmente consideradas, restaram 8 entidades listadas a seguir: 


\section{Quadro 1 - Entidades associadas ao GIFE selecionadas como exemplos}

\begin{tabular}{|l|l|}
\hline 1. Fundação Abrinq pelos Direitos da Criança & 5. Fundação Romi \\
\hline 2. Fundação Bradesco & 6. Instituto Avon \\
\hline 3. Fundação Bunge & 7. Instituto Ayrton Senna \\
\hline 4. Fundação Orsa & 8. Instituto Souza Cruz \\
\hline
\end{tabular}

Além das entidades mencionadas, foram incluídas no estudo a Fundação Salvador Arena e a FIPECAFI que, apesar de não serem associadas do GIFE, possuem grande notoriedade no setor em referência, além de apresentarem origens de receitas necessárias ao presente estudo, contribuindo, portanto, para o enriquecimento da análise do modus operandi das entidades do terceiro setor e das origens de receitas possíveis.

\section{Quadro 2 - Entidades selecionadas como exemplo}

\begin{tabular}{|l|l|}
\hline 1. Fundação Abrinq pelos Direitos da Criança & 6. Fundação Romi \\
\hline 2. Fundação Bradesco & 7. Fundação Salvador Arena \\
\hline 3. Fundação Bunge & 8. Instituto Avon \\
\hline $\begin{array}{l}\text { 4. Fundação Instituto de Pesquisas Contábeis, } \\
\text { Atuariais e Financeiras }\end{array}$ & 9. Instituto Ayrton Senna \\
\hline 5. Fundação Orsa & 10. Instituto Souza Cruz \\
\hline
\end{tabular}

\subsection{Estrutura do trabalho}

Este trabalho divide-se em quatro capítulos. O primeiro capítulo contém a introdução subdividida em contextualização, questão de pesquisa, objetivos, justificativa para escolha do tema e contornos da pesquisa.

O segundo capítulo é composto pela plataforma teórica que sustenta o presente estudo relacionado ao terceiro setor, suas especificidades e a importância da Contabilidade para divulgação das diversas obrigações impostas às entidades qualificadas como beneficentes e os benefícios da utilização da DVA na transparência na prestação de contas dessas entidades, bem como sua importância para o cálculo do PIB.

Inicia-se o capítulo três com a apresentação dos conceitos operacionais das diferentes origens de recursos das entidades de interesse social. Em seguida, são expostos os resultados da tese 
de doutoramento de Fregonesi acerca da melhor forma de evidenciação dos investimentos socioambientais na DVA dos investidores. O que se busca neste capítulo é vislumbrar uma possível uniformidade de procedimentos entre as formas de evidenciação de quem faz o investimento socioambiental e de quem os recebe.

Por fim, no capítulo quatro são apresentadas a conclusão e as considerações finais do estudo. 


\section{PLATAFORMA TEÓRICA}

\subsection{Terceiro setor}

\subsubsection{Breve histórico do desenvolvimento do terceiro setor no Brasil}

Os países anglo-saxônicos, que possuem avançado arcabouço legal e teórico do terceiro setor, diferente em relação ao ordenamento jurídico brasileiro, distinguem o setor em duas categorias: a primeira formada pelas organizações de interesse ou caráter público (defesa de interesses mais amplos da sociedade ou para o desenvolvimento de uma atividade que traz benefícios para a sociedade como um todo, mesmo que aparentemente, ela se dedique apenas a beneficiar agrupamentos específicos, como por exemplo, populações carentes, aidéticos) e a segunda integrada pelas organizações ou agrupamentos que se formam para defender interesses coletivos, mas de um círculo restrito, específico, de pessoas, como, por exemplo, associação de classe, clube social ou associação de moradores de uma determinada zona da cidade (PAES, 2006, p. 123).

Nesses países, expressões como third sector, Non-profit sector, public charities e voluntary são utilizadas para designar entidades não governamentais, sem fins lucrativos que, no Brasil denomina-se terceiro setor.

Apesar de amplamente utilizado, o termo, no Brasil, é controverso por apresentar um problema conceitual, sobretudo no que se refere à sua abrangência. Alguns autores como Santos apud Paes (2006, p. 122) consideram o termo residual e vago por pretender abranger um vastíssimo conjunto de organizações sociais e entidades da sociedade civil. Na outra ponta, Lester Salamon, coordenador de uma das maiores pesquisas já realizadas sobre terceiro setor no mundo, na concepção de Dias (2008), acredita que a preservação e o reforço dessas diferenças constituiriam exatamente o elemento mantenedor e de fortalecimento da atuação dessas entidades e não a busca de homogeneidade de conceito e tratamento legal.

Em termos históricos Corullón apud Coelho (2002, p. 73) afirma que desde o século XVI se observa no Brasil, instituições orientadas por fins filantrópicos devido à influência do modelo português das Casas de Misericórdia, baseadas em ações caritativas e cristãs. 
De acordo com o estudo do IBGE (2005) as instituições sem fins lucrativos apresentam um maior crescimento entre o período de 1991 a 2000, conforme Tabela 1 abaixo.

Tabela 1 - Faixas de ano de fundação e unidades locais das Fundações Privadas e Associações sem Fins Lucrativos - Brasil - 2005

\begin{tabular}{|l|c|}
\hline Ano de fundação & Unidades locais \\
\cline { 2 - 3 } Até 1970 & 10.939 \\
\hline 1971 a 1980 & 33.408 \\
\hline 1981 a 1990 & 64.388 \\
\hline 1991 a 2000 & 140.261 \\
\hline 2001 a 2004 & 73.847 \\
\hline 2005 & 15.319 \\
\hline
\end{tabular}

FONTE: IBGE (2005).

Apesar de existir desde o século XVI, o terceiro setor começa a apresentar novos padrões de articulação em anos do regime militar (1964-1985). E pela própria filosofia do período, de modernização do país ainda que em período autoritário, as organizações não governamentais surgem na década de 70 do século passado.

Conforme Zarpelon (2003) o crescimento das organizações não governamentais observado no final da década de 1980, início da década de 1990, explica-se principalmente em razão do avanço das políticas neoliberais, através das quais elas foram colocadas em evidência. Neste sentido, vale lembrar a ECO-92, importante evento que reuniu organizações governamentais e não governamentais do mundo inteiro para debate de questões ambientais.

A partir da primeira metade da década de 1990 o campo composto até então de organizações não governamentais cidadãs, militantes propriamente ditas, com perfil ideológico e projeto político definidos misturou-se a entidades mais articuladas a empresas e fundações. $\mathrm{Na}$ segunda metade da década de 1990, a conjuntura econômica provoca alterações na dinâmica das organizações não governamentais, que passam a ser patrocinadas também pela iniciativa privada, dentro dos chamados programas de responsabilidade social (ACIOLI, 2008). 


\subsubsection{Entidades do Terceiro setor}

Diversas são as denominações aplicadas às entidades que compõem o terceiro setor: organização não-governamental (ONG), organização da sociedade civil de interesse público (OSCIP), instituto, instituição, dentre outras. No entanto, é importante destacar que apesar de as pessoas jurídicas atuantes neste setor serem identificadas de diferentes modos, são juridicamente constituídas sob a forma de associação ou fundação e são regidas pelo Código Civil.

\subsubsection{Associações}

As associações são pessoas jurídicas de direito privado, sem fins econômicos ou lucrativos, que se forma pela reunião de pessoas em prol de um objetivo comum, sem interesse em dividir resultado financeiro.

Toda renda proveniente de suas atividades deve ser revertida para seus objetivos estatutários. Conforme dispõe o Código Civil de 2002 é obrigatório que no estatuto da associação estejam previamente estabelecidas as fontes de recursos para sua manutenção.

No que se refere ao patrimônio das associações não há disposição expressa constante no Código Civil quanto à sua obrigatoriedade. Entretanto, tendo em vista a inviabilidade de atividade associativa sem aporte de recursos, na prática, o patrimônio demonstra ser uma fonte natural de recursos que poderá ser transferido no momento da constituição da associação, por meio de doação dos associados ou ao longo de sua existência através de eventuais superávits de suas atividades.

Outra fonte de recursos observada nas associações está nas receitas que obtém como resultado de suas atividades. São as provenientes de prestações de serviços, doações, subvenções sociais dentre outras modalidades.

\subsubsection{Fundações}


Ao contrário das associações, um requisito essencial para a existência de uma fundação é o patrimônio de dotação real. Tendo em vista que a base de toda a atividade de uma fundação justifica-se pela existência de um patrimônio, a ele deve ser reservado um capítulo à parte do estatuto da fundação. O patrimônio desta entidade componente do terceiro setor deve, conforme dispõe o art. 62 do Código Civil, ser composto de bens livres e destinados a uma finalidade específica.

As receitas das fundações possuem diversas fontes, podendo ter como origem a prestação de serviços, os usufrutos eventualmente concedidos, rendas provenientes de títulos, ações ou ativos financeiros de sua propriedade ou de operações de créditos, rendas auferidas de seu patrimônio, de venda de produtos, publicações e participação em empresas e empreendimentos.

A diferença basilar entre associações e fundações está, portanto, relacionada ao patrimônio; enquanto as fundações caracterizam-se como um patrimônio afetado a um fim (BARBOSA; OLIVEIRA, 2011, p. 13) e submetidas à fiscalização do Ministério Público, as associações caracterizam-se pela reunião de pessoas não sendo pré-requisito o patrimônio prévio.

Ainda no que se refere às diferenças básicas entre associações e fundações, a Ordem dos Advogados do Brasil (OAB), com o objetivo de fornecer informações básicas sobre o terceiro setor publicou um documento denominado Cartilha do Terceiro Setor onde consta um quadro comparativo de tais entidades:

\section{Quadro 3 - Diferenças entre Associação e Fundação}

\begin{tabular}{|l|l|}
\hline \multicolumn{1}{|c|}{ Associação } & \multicolumn{1}{c|}{ Fundação } \\
\hline Constituída por pessoas. & $\begin{array}{l}\text { Constituída por patrimônio, aprovado previamente } \\
\text { pelo Ministério Público. }\end{array}$ \\
\hline Pode (ou não) ter patrimônio inicial. & O patrimônio é condição para sua criação. \\
\hline A finalidade é definida pelos associados. & $\begin{array}{l}\text { A finalidade deve ser religiosa, moral, cultural ou } \\
\text { de assistência, definida pelo instituidor. }\end{array}$ \\
\hline A finalidade pode ser alterada. & A finalidade é perene. \\
\hline Os associados deliberam livremente. & $\begin{array}{l}\text { As regras para deliberações são definidas pelo } \\
\text { instituidor e fiscalizadas pelo Ministério Público. }\end{array}$ \\
\hline Registro e administração são mais simples. & Registro e administração são mais burocráticos. \\
\hline Regida pelos artigos 44 a 61 do Código Civil. & Regida pelos artigos 62 a 69 do Código Civil. \\
\hline $\begin{array}{l}\text { Criada por intermédio de decisão em assembleia, } \\
\text { com transcrição em ata e elaboração de um } \\
\text { estatuto. }\end{array}$ & $\begin{array}{l}\text { Criada por intermédio de escritura pública ou } \\
\text { testamento. Todos os atos de criação, inclusive o } \\
\text { estatuto, ficam condicionados à prévia aprovação } \\
\text { do Ministério Público. }\end{array}$ \\
\hline
\end{tabular}

Fonte: OAB, 2007. 
Em termos constitutivos, ao contrário das empresas com fins lucrativos que ganham reconhecimento jurídico ao registrarem seus contratos nos devidos órgãos públicos, as entidades do terceiro setor registram seus estatutos em um cartório de registro civil de pessoas jurídicas.

As entidades do terceiro setor podem, a seu critério, e desde que atendam a determinadas condições, solicitar titulações, certificados e/ou qualificações concedidas pelo poder público. Os benefícios decorrentes da obtenção desses documentos é a maior credibilidade frente à sociedade, possibilidade de acesso a recursos públicos, bem como a celebração de convênios e parcerias com o primeiro setor, possibilidade de utilização de incentivos fiscais pelos doadores, além de serem necessárias para o gozo de determinadas isenções tributárias.

Cabe aqui um esclarecimento sobre a diferença entre imunidade e isenção. Enquanto a imunidade é uma vedação absoluta ao poder de tributar garantida constitucionalmente, a isenção é a exclusão da hipótese de tributar. Em outras palavras, possui imunidade aquele que se encontra fora do alcance da entidade tributante e isento é aquele que, ainda que dentro do alcance da entidade tributante resta desobrigado por dispositivo legal expresso.

A Constituição Federal, em seu artigo 150, inciso VI, alínea c, dispõe que:

\footnotetext{
"sem prejuízo de outras garantias asseguradas ao contribuinte, é vedado à União, aos Estados, ao Distrito Federal e aos Municípios: instituir impostos sobre: patrimônio, renda ou serviços dos partidos políticos, inclusive suas fundações, das entidades sindicais dos trabalhadores, das instituições de educação e de assistência social, sem fins lucrativos, atendidos os requisitos da lei".
}

Do dispositivo constitucional acima, nota-se que a imunidade tributária alcança somente os impostos cujo fato gerador recaia sobre a renda, patrimônio ou serviços. Isto porque entende que, todo o patrimônio, rendas ou serviços das instituições beneficentes estão destinados a preencher funções complementares às atribuições essenciais do Estado. 
Não obstante, o artigo 14 do Código Tributário Nacional, lei complementar revestida de legitimidade para regular as limitações constitucionais ao poder de tributar, estabelece os pressupostos para que as entidades gozem de imunidade.

O primeiro desses pressupostos é a não distribuição de qualquer parcela do seu patrimônio ou renda, a qualquer título, a seus fundadores, administradores ou mantenedores. A segunda condição para que a entidade usufrua de imunidade constitucional é a proibição de enviar receitas ao exterior, aplicando integralmente, no país, os seus recursos na manutenção dos seus objetivos institucionais. O terceiro e último item condicionante à imunidade das entidades é a exigência de manterem escrituração de suas receitas e despesas em livros revestidos de formalidades capazes de assegurar sua exatidão. A inobservância desses pressupostos pode acarretar na suspensão da imunidade da entidade e sua cassação, dependerá de processo judicial.

As qualificações, títulos e certificados que podem ser requeridos ao poder público pelas fundações, associações e entidades de interesse social são os seguintes: título de utilidade pública, organizações sociais, organizações da sociedade civil de interesse público e certificado de entidade beneficente de assistência social.

Título de utilidade pública - Inicialmente, as declarações de utilidade pública simbolizavam um reconhecimento que determinadas entidades obtinham por cumprirem uma função que deveria ser exercida pelo poder público, não proporcionando qualquer vantagem às entidades agraciadas, podendo ser cassadas na hipótese de não apresentarem anualmente relação circunstanciada dos serviços que houvessem prestado à coletividade (PAES, 2006, p. 639).

Atualmente a obtenção do título de utilidade pública concede às entidades vantagens fiscais (no âmbito federal, estadual e municipal) e financeiras dado que constitui condição sine qua non para o gozo de isenções fiscais ou recebimento de subvenções, auxílios ou doações.

Em âmbito federal, as entidades cujos objetivos relacionem-se à atividades de promoção da educação ou de pesquisa científica, cultura artística ou filantrópica poderão requerer à Divisão de Outorga e Títulos do Ministério da Justiça o título de utilidade pública nos termos da Lei n. 91/35, regulamentada pelo Decreto n. 50.517/61 e da Lei n. 6.639/79, regulamentada pelo Decreto n. 60.931/67 desde que preencham os seguintes requisitos: 
- Ter personalidade jurídica;

- Ser constituída no país;

- Estar em efetivo e contínuo funcionamento nos três últimos anos imediatamente anteriores, com exata observância das finalidades estatutárias;

- Não remunerar, sob qualquer forma, os cargos da diretoria;

- Não distribuir lucros, bonificações ou vantagens a dirigentes, mantenedores ou associados, sob nenhuma forma ou pretexto;

- Seus diretores serem de comprovada idoneidade.

As solicitações deferidas proporcionam à entidade a possibilidade de receber subvenções e auxílios da União, das loterias federais, realizar sorteios, além de instruir o pedido de certificado de entidade beneficente de assistência social, dar o direito de fornecer às pessoas jurídicas, doadoras de benefícios, recibo dedutível do imposto de renda e constituir documento essencial para requerer ao INSS a isenção da quota patronal.

As entidades detentoras do título de utilidade pública federal devem obrigatoriamente apresentar anualmente (até o dia 30 de abril) ao Ministério da Justiça, relatório circunstanciado de atividades e demonstração das receitas e despesas realizadas no período. Caso parte das receitas tenha sido fruto de subvenção da União, o relatório deve ser acompanhado da prova de publicação das demonstrações financeiras (ALVES, 2005, p. 36).

Barbosa e Oliveira (2011) ao descrever sobre os documentos necessários para instruir o pedido de reconhecimento de utilidade pública estadual menciona a necessidade da "publicação - via original do jornal - do balanço, demonstrativo de receitas e despesas, referente ao exercício imediatamente anterior ao pedido." (BARBOSA; OLIVEIRA, 2011, p. $152)$.

Certificado de Entidade Beneficente de Assistência Social (CEBAS) - as entidades interessadas em obter essa certificação devem, inicialmente solicitar o registro no Conselho Nacional de Assistência Social (CNAS). Os requisitos para obtenção do referido registro reserva-se às entidades que promovam as seguintes atividades: 
- Proteção à família, à infância, à maternidade, à adolescência e à velhice;

- Proporcionar amparo às crianças e adolescentes carentes;

- Ações de prevenção, habilitação, reabilitação e integração à vida comunitária de pessoas portadoras de deficiência;

- Integração ao mercado de trabalho;

- Proporcionar assistência educacional ou de saúde;

- Desenvolvimento da cultura;

- Atendimento e assessoramento aos beneficiários da Lei Orgânica de Assistência Social (Loas) e a defesa e garantia de seus direitos.

A fim de instruir o pedido de certificado de entidade beneficente de assistência social (CEBAS) e, juntamente com os títulos de utilidade pública federal e estadual ou municipal e demais documentos, permitindo assim requerer a isenção da quota patronal do INSS, as entidades devem apresentar diversos documentos, dentre os quais estão:

- Balanços Patrimoniais, Demonstrativos do resultado, Demonstração de Mutação do Patrimônio e Notas Explicativas dos três exercícios anteriores ao da solicitação, assinados pelo representante legal da entidade e por técnico registrado no Conselho Regional de Contabilidade;

As notas explicativas devem evidenciar o resumo das principais práticas contábeis e os critérios de apuração do total das receitas, das despesas, da gratuidade, do tipo de clientela beneficiada com atendimento gratuito, bolsas de estudos, das doações, das subvenções e das aplicações de recursos, bem como da mensuração dos gastos e despesas relacionadas com a atividade assistencial.

Adicionalmente, a tais entidades será exigida auditoria realizada por auditores independentes registrados na Comissão de Valores Mobiliários (CVM) quando a receita bruta auferida em qualquer dos últimos três exercícios for superior a $\mathrm{R} \$ 3.600 .000,00$ conforme Decreto n. 7.300 de 14 de setembro de 2010.

A análise e decisão dos requerimentos de concessão ou de renovação dos certificados das entidades beneficentes de assistência social serão apreciadas no âmbito dos seguintes 
Ministérios: (i) da Saúde, quanto às entidades da área da saúde; (ii) da Educação, quanto às entidades educacionais; e (iii) do Desenvolvimento Social e Combate à Fome, quanto às entidades de assistência social.

Qualificação como Organização da Sociedade Civil de Interesse Público (Oscip) - a entidade interessada poderá requerer tal qualificação desde que atenda a uma das seguintes finalidades:

- Promoção da assistência social;

- Promoção da cultura, defesa e conservação do patrimônio histórico e artístico;

- Promoção gratuita da educação, observando-se a forma complementar de participação de que trata a Lei n. 9.790 de 23 de março de 1999, regulamentada pelo Decreto n. 3.100 de 30 de junho de 1999;

- Promoção gratuita da saúde, observando-se a forma complementar de participação das organizações de que trata a Lei n. 9.790 de 23 de março de 1999, regulamentada pelo Decreto n. 3.100 de 30 de junho de 1999;

- Promoção da segurança alimentar e nutricional;

- Defesa, preservação e conservação do meio ambiente e promoção do desenvolvimento sustentável;

- Promoção do voluntariado;

- Promoção do desenvolvimento econômico e social e combate à pobreza;

- Experimentação, não-lucrativa, de novos modelos socioprodutivos e de sistemas alternativos de produção, comércio, emprego e crédito;

- Promoção de direitos estabelecidos, construção de novos direitos e assessoria jurídica gratuita de interesse suplementar;

- Promoção da ética, da paz, da cidadania, dos direitos humanos, da democracia e de outros valores universais;

- Promoção de estudos e pesquisas e desenvolvimento de tecnologias alternativas, produção e divulgação de informações e conhecimentos técnicos e científicos.

Além disso, são requisitos para que a entidade seja qualificada como OSCIP, que o estatuto disponha sobre: 
- A observância dos princípios da legalidade, impessoalidade, moralidade, publicidade, economicidade e eficiência;

- A adoção de práticas de gestão administrativa, necessárias e suficientes para coibir a obtenção, de forma individual ou coletiva, de benefícios ou vantagens pessoais, em decorrência da participação no respectivo processo decisório;

- A constituição de conselho fiscal ou órgão equivalente, dotado de competência para opinar sobre os relatórios de desempenho financeiro e contábil, e sobre as operações patrimoniais realizadas, emitindo pareceres para os organismos superiores da entidade;

- A previsão de que, em caso de dissolução da entidade, o respectivo patrimônio líquido será transferido a outra pessoa jurídica qualificada nos termos da Lei n. 9.790 de 23 de março de 1999, regulamentada pelo Decreto n. 3.100 de 30 de junho de 1999, preferencialmente que tenha o mesmo objeto social da extinta;

- A previsão de que, na hipótese de a pessoa jurídica perder a qualificação instituída por esta lei, o respectivo acervo patrimonial disponível, adquirido com recursos públicos durante o período em que perdurou aquela qualificação, seja transferido a outra pessoa jurídica qualificada nos termos da acima mencionada, preferencialmente com o mesmo objeto social;

- A possibilidade de se instituir remuneração para os dirigentes da entidade, que atuem efetivamente na gestão executiva e para aqueles que a ela prestam serviços específicos, respeitados, em ambos os casos, os valores praticados pelo mercado, na região correspondente à sua área de atuação.

O estatuto deve mencionar, inclusive, as normas de prestação de contas a serem observadas pela entidade, que determinarão, no mínimo:

- A observância dos princípios fundamentais de contabilidade e das normas brasileiras de contabilidade;

- Que se dê publicidade, por qualquer meio eficaz, no encerramento do exercício fiscal, ao relatório de atividades e demonstrações financeiras da entidade, incluindo-se as certidões negativas de débitos junto ao INSS e ao FGTS, colocando-as à disposição para exame de qualquer cidadão; 
- A realização de auditoria, inclusive por auditores externos independentes, se for o caso, da aplicação dos eventuais recursos objetos do termo de parceria, conforme previsto em regulamento.

A prestação de contas de todos os recursos e bens de origem pública recebidos pelas organizações da sociedade civil de interesse público será feita conforme determina o parágrafo único do artigo 70 da Constituição Federal.

Prestará contas qualquer pessoa física ou jurídica, pública ou privada, que utilize, arrecade, guarde, gerencie ou administre dinheiros, bens e valores públicos ou pelos quais a União responda, ou que, em nome desta, assuma obrigações de natureza pecuniária.

No último estudo realizado pelo Gife (2009-2010), quanto à certificação do investidor social privado, da base de 70 respondentes, o censo mostrou a preferência dos associados por títulos como Oscip (44\%), Utilidade Pública Federal (43\%) e Utilidade Pública Estadual (30\%). Justifica tal preferência tanto pela maior agilidade na contratação com o governo, quanto pela possibilidade de acesso a incentivos fiscais.

A seguir apresenta-se um quadro-resumo das principais certificações/titulações possíveis às entidades sem fins lucrativos que permitem seu acesso a determinados benefícios, inclusive isenções tributárias.

\section{Quadro 4 - Resumo dos tipos de certificação/titulação das ESFL e respectivos benefícios}

\begin{tabular}{|l|l|}
\hline Certificação/Titulação & Benefícios \\
\hline Utilidade Pública Federal & $\begin{array}{l}* \text { Pré-requisito para, junto com outros documentos, requerer isenção da } \\
\text { quota patronal do INSS. } \\
* \text { Possibilidade de fornecer às pessoas jurídicas, doadoras de benefícios, } \\
\text { recibo dedutível do imposto de renda. } \\
* \text { Possibilita receber: } \\
* \text { doações da União } \\
* \text { receitas das loterias federais }\end{array}$ \\
& $\begin{array}{l}* \text { Possibilita realizar sorteios } \\
\text { Utilidade Pública Estadual }\end{array}$ \\
& $\begin{array}{l}* \text { Reconhecimento de idoneidade no âmbito estadual. } \\
\text { quota patronal do INSS. }\end{array}$ \\
\hline Utilidade Pública Municipal & $\begin{array}{l}* \text { Reconhecimento de idoneidade no âmbito municipal. } \\
\text { Pré-requisito para, junto com outros documentos, requerer isenção da }\end{array}$ \\
& $\begin{array}{l}* \text { Facta patronal do INSS. } \\
\text { municipais. }\end{array}$ \\
\hline
\end{tabular}




\begin{tabular}{|l|l|}
\hline $\begin{array}{l}\text { Certificado de Entidade } \\
\text { Beneficente de Assistência Social } \\
\text { (Cebas) }\end{array}$ & $*$ Instruir o pedido de certificado de entidade de fins filantrópicos. \\
\hline $\begin{array}{l}\text { Organização da Sociedade Civil } \\
\text { de Interesse Público (Oscip) }\end{array}$ & $\begin{array}{l}\text { * Possibilidade de celebração do termo de parceria com o poder público. } \\
\text { P Possibilidade de receber doações, dedutíveis do imposto de renda de } \\
\text { pessoa jurídica. } \\
\text { * Possibilidade de remuneração dos dirigentes. }\end{array}$ \\
\hline
\end{tabular}

Fonte: Adaptado de BARBOSA; OLIVEIRA (2011)

\title{
2.1.3 A importância da prestação de contas para o terceiro setor
}

Pelo fato de desempenharem atividades de interesse público e muitas vezes dependerem da divulgação de seus projetos e consequentes resultados a fim de angariarem recursos para manutenção de suas atividades, é importante que as organizações de terceiro setor cultivem a transparência (accountability).

Neste contexto, Olak e Nascimento (2010) citam Marcovitch ${ }^{3}$ :

\begin{abstract}
"[...] por desempenhar função de interesse público, espera-se que a organização do Terceiro Setor cultive a transparência quanto ao seu portfólio de projetos e, também, quanto aos resultados obtidos e os recursos alocados. $\mathrm{O}$ diagnóstico ex-ante e a avaliação ex-post constituem instrumentos determinantes para o êxito e o apoio a ser obtido em iniciativas futuras. Nesse sentido, a preparação de relatórios de avaliação, e a sua disseminação constituem importantes instrumentos de comunicação com a sociedade."
\end{abstract} (OLAK; NASCIMENTO, 2010, p. 20).

O termo accountability segundo Lopes e Martins (2007, p. 114) "se refere às características de transparência e de clareza nas relações entre as partes envolvidas em um contrato, seja ele formal ou tácito". Não se restringe ao aspecto financeiro de fontes de recursos e gastos, mas também da eficiência e do resultado das atividades desempenhadas pelas entidades. Nas palavras de Nakagawa (1987, p. 17) "é a obrigação de prestar contas dos resultados obtidos, em função das responsabilidades que decorrem de uma delegação de poderes".

Para Olak e Nascimento (2010, p.21), no âmbito das entidades sem fins lucrativos, essa delegação de poderes ocorre quando a sociedade contribui com estas entidades por meio do

\footnotetext{
${ }^{3}$ MARCOVITCH, Jacques. Da exclusão à coesão social: profissionalização do Terceiro Setor. In: $3^{\circ}$ Setor: desenvolvimento social sustentado. Rio de Janeiro: Paz e Terra, 1997.
} 
pagamento de impostos ao Estado (subventores destas entidades) ou mesmo diretamente na forma de doações materiais ou pecuniárias, serviços voluntários ou quando paga por algum tipo de serviço por elas prestado.

A ausência de prestação de contas para estas entidades comprometem não apenas projetos futuros como a imagem do setor, dando margem para que a sociedade insira em uma mesma cesta, entidades de fato comprometidas com o bem-estar social com aquelas que promovem a malversação dos recursos arrecadados.

Importante ressaltar também o elevado nível de transparência exigido das entidades sem fins lucrativos que recebem capital externo para financiar suas atividades. Essa cobrança por maior transparência ocorreu após os atentados de 11 de setembro onde posteriormente foi descoberto que tinham ligação indireta com o financiamento de entidades sem fins lucrativos, vinculadas à comunidade muçulmana nos Estados Unidos. Segundo Szazi (2006) "esse ambiente de maior preocupação com o terrorismo e a lavagem de dinheiro levou a um escrutínio inédito dos gastos das organizações nos EUA e na Europa".

É relevante que a sociedade, de modo geral, se interesse pela elevação no nível de prestação de contas das entidades do terceiro setor porque estas, em muitos casos, recebem recursos do Estado, mas que não foram gerados por ele, sendo fruto de recursos da própria sociedade, entregues à gestão do governo, para que este aplique eficiente e eficazmente no bem-estar público.

Na visão de Olak e Nascimento (2010, p. 23) um importante instrumento de transparência na gestão das entidades sem fins lucrativos é a prestação de contas por meio de de relatórios da administração que além de serem compostos por elementos que identificam aspectos históricos da instituição, missão e objetivos, dados estatísticos, evolução, atividades desenvolvidas no período, integram algumas demonstrações contábeis e respectivas notas explicativas, além do parecer de auditores independentes.

No tocante à necessidade de apresentação de relatório de auditores independentes, legalmente habilitados pelos Conselhos Regionais de Contabilidade, para as demonstrações contábeis das entidades sem fins lucrativos apenas fazem tal exigência o Conselho Nacional de Assistência Social, no momento da certificação ou renovação da entidade como beneficente de assistência 
social e o Ministério da Justiça, para os casos em que os recursos recebidos pela OSCIP, por meio de termos de parceria for maior ou igual a $\mathrm{R} \$ 600.000,00$ e na hipótese de celebração de mais de um termo de parceria, com um ou vários órgãos estatais, cuja soma ultrapasse o referido valor anual.

\subsubsection{Especificidades das Demonstrações Contábeis}

As demonstrações contábeis exigidas das entidades do terceiro setor eram as determinadas pela NBC T 3, isto é, Balanço Patrimonial, Demonstração do Resultado, Demonstração de Lucros ou Prejuízos Acumulados, Demonstração das Mutações do Patrimônio Líquido e Demonstração das Origens e Aplicações de Recursos.

Pelo fato de as entidades sem fins de lucro não possuírem sócios capitalistas e sim associados que colaboram para sua constituição e manutenção, adaptações terminológicas devem ser observadas pelas ESFL. A conta capital deve ser substituída por patrimônio social e, por não possuir fins lucrativos, o resultado de suas operações deve ser denominado superávit ou déficit.

No entanto, apesar de as demonstrações contábeis dessas entidades serem meras adaptações daquelas das sociedades lucrativas, é importante sopesar se de fato são adequadas para manter o poder informativo e preditivo aos diversos interessados acerca da situação econômicofinanceira dessas entidades.

Um exemplo a ser citado é a Demonstração do Resultado que tem a finalidade principal de evidenciar o lucro ou prejuízo líquido dos acionistas. Para as entidades sem fins de lucro, o importante seria demonstrar em um determinado período, o modo como os recursos foram captados, quanto foi arrecadado e quanto foi convertido de fato em bem-estar para a sociedade de forma geral.

Importante destacar que a referida Norma Brasileira de Contabilidade (NBC T 3) foi revogada sendo aplicável atualmente, a NBC TG 26 - Apresentação das Demonstrações Contábeis. 
2.1.4 Legislação contábil aplicável às entidades do Terceiro setor

As entidades que compõem o terceiro setor são regidas por diversas bases legais. O quadro 6 a seguir apresenta uma breve compilação das principais legislações aplicáveis às entidades sem fins lucrativos.

\section{Quadro 5 - Legislação do Terceiro Setor}

\begin{tabular}{|c|c|c|}
\hline Norma & Dispositivo Legal & Assunto \\
\hline \multirow[t]{2}{*}{$\begin{array}{l}\text { Constituição } \\
\text { Federal/1988 }\end{array}$} & Artigo 150, VI, "c" & $\begin{array}{l}\text { Veda à União, aos Estados, ao Distrito } \\
\text { Federal e aos Municípios instituir impostos } \\
\text { sobre o patrimônio, renda ou serviços } \\
\text { relacionados com as finalidades essenciais } \\
\text { dos partidos políticos, inclusive suas } \\
\text { fundações, das instituições de educação e de } \\
\text { assistência social, sem fins lucrativos, } \\
\text { atendidos os requisitos da lei. }\end{array}$ \\
\hline & Artigo 195, VII & $\begin{array}{l}\text { Isenção de contribuição para a seguridade } \\
\text { social das entidades beneficentes de } \\
\text { assistência social que atendam as exigências } \\
\text { estabelecidas em lei. }\end{array}$ \\
\hline \multicolumn{2}{|l|}{ Lei ${ }^{\circ} 9.790 / 2009$} & $\begin{array}{l}\text { Trata das organizações da sociedade civil de } \\
\text { interesse público (OSCIP). }\end{array}$ \\
\hline \multicolumn{2}{|l|}{ Lei $^{\circ} 12.101 / 2009$} & $\begin{array}{l}\text { Dispõe sobre o processo de certificação das } \\
\text { entidades beneficentes de assistência social } \\
\text { para obtenção da isenção das contribuições } \\
\text { para a seguridade social e dá outras } \\
\text { providências. }\end{array}$ \\
\hline \multicolumn{2}{|l|}{ NBC T 10} & $\begin{array}{l}\text { Aspectos contábeis específicos de entidades } \\
\text { diversas }\end{array}$ \\
\hline \multicolumn{2}{|l|}{ NBC T 10.4} & Fundações \\
\hline \multicolumn{2}{|l|}{ NBC T 10.18} & $\begin{array}{l}\text { Entidades sindicais e Associações de } \\
\text { Classe. }\end{array}$ \\
\hline NBC T 10.19 & & Entidades sem finalidade de lucros. \\
\hline
\end{tabular}

Adicionalmente, e de acordo com recente estudo de Bulgarin et al (2012), as Normas Brasileiras de Contabilidade que podem de alguma forma, ter aplicação nas entidades do Terceiro Setor são as seguintes:

- NBC TG 00 - Estrutura Conceitual para Elaboração e Apresentação das Demonstrações Contábeis.

- $\quad$ NBC TG 07 - Subvenção e Assistência Governamentais.

- $\quad$ NBC TG 26 - Apresentação das Demonstrações Contábeis. 
- NBC TE - Entidades sem finalidade de lucros (ainda não aprovada por Resolução do CFC).

- Resolução do Conselho Federal de Contabilidade n. 750/93 (alterada pela Resolução CFC n. 1.282/10).

- ITG 2000 - Escrituração Contábil.

\subsection{Balanço Social e Demonstração do Valor Adicionado}

O Balanço Social, também denominado Relatório Social, Relatório Social-Ambiental, Relatório de Sustentabilidade Social tem por finalidade divulgar informações qualitativas e quantitativas acerca do desempenho das funções ambientais e sociais da empresa, que interessam não somente aos acionistas, alcançando também outros stakeholders, a exemplo dos sindicatos, empregados e comunidades afetadas por suas ações.

Segundo Tinoco (2010, p. 2-3), essa demonstração surgiu nos Estados Unidos, por volta dos anos 60 , quando a sociedade americana passou a exigir de suas empresas uma postura moral e ética perante os cidadãos. Já nas décadas seguintes, outros países europeus passaram a adotála, como a França, Alemanha, Portugal e Bélgica, dentre outros países.

A fim de evidenciar informações ambientais e sociais, o Balanço Social é composto por quatro vertentes, a saber: (i) Balanço Ambiental onde a empresa divulga suas práticas relacionadas à proteção e à preservação do meio ambiente, (ii) Balanço de Recursos Humanos que contempla informações acerca do quadro de funcionários da empresa, (iii) Relatório de Projetos Sociais cujo enfoque reside na divulgação de informações sobre a política e os gastos das empresas em atividades sociais e (iv) Demonstração do Valor Adicionado que apresenta a riqueza criada pela empresa e sua distribuição entre os diversos elementos que contribuíram para sua criação.

Com vistas a proporcionar transparência de suas atividades à sociedade, diversas são as empresas que vêm divulgando seus Balanços Sociais. Em um estudo conduzido por Oliveira (2005), das 500 maiores empresas não financeiras divulgadas pela Fundação Getúlio Vargas em agosto de 2002, com dados relativos a 2001, 30,4\% delas divulgaram seus Balanços Sociais. 
Segundo Paes (2006, p. 489), a intenção das empresas que exercem um papel social e que divulgam o Balanço Social é conquistar maior respeito perante a sociedade e, consequentemente, atrair mais clientes. Mas questiona a utilidade informativa ou complementar do Balanço Social para as entidades sem fins lucrativos, comparativamente às demonstrações contábeis já impostas a tais entidades. A fim de dar resposta à questão, cita a análise de Chaves Neto $(2001)^{4}$ que entende que a sociedade como grande financiadora das atividades do Terceiro Setor, embora se interesse sobre a receita anual de uma entidade, a aplicação desses recursos e seu resultado, se interessa com maior ênfase em conhecer quantas pessoas foram atendidas e qual o nível desse atendimento, sendo o Balanço Social a ferramenta mais inclinada a atender essa necessidade informacional em detrimento das demais demonstrações contábeis.

Diversos são os organismos (por exemplo, ONU, GRI, Ibase, Ethos) que emitem recomendações sobre a elaboração de relatórios sociais objetivando compilar os principais elementos a serem evidenciados em termos de responsabilidade social praticadas pelas empresas.

De acordo com De Luca et al (2009, p. 15) a GRI é uma organização não governamental internacional, com sede em Amsterdã, criada em 1997 pelo Programa das Nações Unidas para o Meio Ambiente (PNUMA) e pela entidade norte-americana Coalition for Environmentally Responsible Economies (Ceres) cujo objetivo é desenvolver, aprimorar e disseminar, globalmente, diretrizes para a elaboração de relatórios de sustentabilidade utilizados voluntariamente por empresas de todo o mundo. Ainda, procura atribuir aos relatórios de sustentabilidade a mesma utilidade e seriedade dos relatórios financeiros, conferindo-lhes status de documento.

Os relatórios de sustentabilidade elaborados conforme a metodologia do GRI evidenciam informações relacionadas à forma de gestão sobre o desempenho econômico, ambiental e social. O primeiro indicador de desempenho econômico, denominados de EC1 pelo GRI, refere-se ao valor econômico direto gerado e distribuído pelas entidades, incluindo receitas, custos operacionais, remuneração de empregados, doações e outros investimentos na

\footnotetext{
${ }^{4}$ CHAVES NETO, Joel Rodrigues. A Contabilidade aplicada ao Terceiro Setor. Gazeta Contábil, Ano X - ${ }^{\circ}$ 47, novembro/dezembro de 2001, Conselho Regional de Contabilidade do Distrito Federal.
} 
comunidade, lucros acumulados e pagamentos para provedores de capital e governo (GRI, 2006a, p. 26)

Constam no conjunto de protocolos de indicadores do GRI, orientações para inserção de dados nas linhas da tabela de valor econômico gerado e distribuído (EVG\&D), cuja estrutura é apresentada no quadro 7 a seguir.

O mesmo conjunto de protocolos recomenda que os dados da tabela EVG\&D deverão ser compilados, sempre que possível, com dados apresentados nas demonstrações financeiras ou de lucros e perdas auditadas da organização ou nos seus relatórios de gestão auditados internamente (GRI, 2006b, p. 4)

\section{Quadro 6 - Tabela de Valor Econômico Gerado e Distribuído (EVG\&D) do GRI}

\begin{tabular}{|l|l|}
\hline Componente & Comentário \\
\hline Valor econômico direto gerado & $\begin{array}{l}\text { Vendas líquidas mais receitas provenientes de } \\
\text { investimentos financeiros e venda de ativos. }\end{array}$ \\
\hline a) Receitas & $\begin{array}{l}\text { Pagamentos para fornecedores, investimentos não } \\
\text { estratégicos, royalties e pagamentos de facilitação. }\end{array}$ \\
\hline Valor econômico distribuído & $\begin{array}{l}\text { Total da folha de pagamento para empregados. } \\
\text { (pagamentos atuais, e não as obrigações futuras) }\end{array}$ \\
\hline b) Custos operacionais & $\begin{array}{l}\text { Todos os pagamentos financeiros feitos aos } \\
\text { provedores de capital da organização }\end{array}$ \\
\hline c) Salários e benefícios de empregados & Impostos brutos \\
\hline d) Pagamentos para provedores de capital & $\begin{array}{l}\text { Contribuições voluntárias e investimento de } \\
\text { fundos na comunidade como um todo (inclui } \\
\text { doações). }\end{array}$ \\
\hline e) Pagamentos ao governo & Investimentos, hipotecas, etc. \\
\hline f) Investimentos na comunidade & \\
\hline $\begin{array}{l}\text { Valor econômico acumulado (calculado como } \\
\text { valor econômico gerado menos valor econômico } \\
\text { distribuído) }\end{array}$ & \\
\hline
\end{tabular}

Fonte: GRI (2006b, p. 5)

Na linha de Receitas, que pela concepção do GRI compõe o valor econômico direto gerado pela entidade, deverão constar:

- As vendas líquidas, que correspondem às vendas brutas de produtos e serviços, menos devoluções, descontos e abatimentos;

- As receitas de investimentos financeiros que incluem dinheiro recebido na forma de juros sobre empréstimos financeiros, rendimentos provenientes de participações de capital, como royalties e como renda direta gerada de ativos, como por exemplo, aluguel de propriedades; 
- As receitas de vendas de ativos que incluem ativos físicos (propriedade, infraestrutura, equipamentos) e intangíveis (direitos de propriedade intelectual, modelos e nomes de marcas) (GRI, 2006b, p. 4).

$\mathrm{Na}$ linha $\mathrm{b}$ da tabela EVG\&D os custos operacionais referem-se a:

- Pagamentos em dinheiro feitos fora da organização relatora referentes a materiais, componentes de produtos, instalações e serviços adquiridos. Isso inclui aluguel de propriedade, taxas de licença, pagamentos de facilitação (desde que tenham um claro objetivo comercial), royalties, pagamentos para trabalhadores terceirizados, custos de treinamento de empregados (onde forem utilizados instrutores externos), equipamentos de proteção para empregados, etc. (GRI, 2006b, p. 5).

As linhas 'c', 'd' e 'e' da tabela EVG\&D equivalem àquelas constantes como distribuição de valor adicionado na DVA. O que vale ressaltar é a linha destinada a evidenciar a distribuição do valor econômico gerado pelas entidades aos investimentos na comunidade, assim como propõe Fregonesi (2009, p. 162).

Conforme instrui o GRI, na linha 'f' - Investimentos na comunidade -, deverão constar:

- Doações voluntárias e investimento de recursos na comunidade, sendo os beneficiários externos à empresa. Estas incluem contribuições a instituições de caridade, ONGs e institutos de pesquisa (não relacionados ao departamento de Pesquisa e Desenvolvimento da empresa), recursos para apoiar projetos de infraestrutura da comunidade (ex.: áreas de lazer) e custos diretos de programas sociais (incluindo eventos artísticos e educativos). Os valores incluídos deverão representar as despesas reais do período coberto pelo relatório e não as obrigações.

- Para investimentos em infra-estrutura, o cálculo do investimento total deverá incluir custos de material e mão-de-obra além dos custos de capital. Para patrocínio a serviços ou programas em andamento (ex.: uma organização financia as operações diárias de um serviço público), o investimento relatado deverá incluir os custos operacionais.

- Isso exclui atividades legais e comerciais, ou cujo propósito do investimento seja exclusivamente comercial. Doações para partidos políticos são incluídas, mas também são abordadas em separado e mais detalhadamente no indicador SO6.

- Quaisquer investimentos em infra-estrutura motivados principalmente por necessidades empresariais essenciais (ex.: construção de uma estrada para uma mina ou fábrica) ou que visem facilitar as operações de negócio da organização não deverão ser incluídos. O cálculo dos investimentos poderá incluir infra-estrutura 
construída fora das principais atividades de negócio da organização relatora, tais como uma escola ou hospital para os empregados e seus familiares. (GRI, 2006b, p. 6).

Admitindo-se as vantagens da divulgação do Balanço Social pelas entidades sem fins lucrativos e sabendo que a DVA a ele se integra, qual seria a utilidade informacional da DVA para as entidades do terceiro setor?

A DVA, relatório contábil componente do Balanço Social tem por finalidade evidenciar a riqueza criada pela entidade durante determinado período e como tal riqueza foi distribuída aos diversos fatores produtivos que contribuíram para sua formação.

Conforme afirma De Luca et al. (2009, p. 30), a DVA está "[...] estreitamente relacionada com o conceito de responsabilidade social [...]" que, por sua vez, tem como principal fundamento a preocupação das empresas em prestar contas à sociedade, quando conscientes de que vêm assumindo o papel de peças fundamentais para o desenvolvimento econômico e social de uma nação.

A estrutura da DVA conforme consta no Pronunciamento Técnico CPC 09 é a apresentada a seguir:

Quadro 7 - Modelo CPC de DVA

\begin{tabular}{|l|}
\hline DESCRIÇÃO \\
\hline 1 - RECEITA \\
\hline 1.1) Vendas de mercadorias, produtos e serviços \\
\hline 1.2) Outras receitas \\
\hline 1.3) Receitas relativas à construção de ativos próprios \\
\hline 1.4) Perdas estimadas em créditos de liquidação duvidosa - Reversão/(Constituição) \\
\hline $\begin{array}{l}\text { 2 - INSUMOS ADQUIRIDOS DE TERCEIROS (inclui valores dos impostos - ICMS, IPI, PIS e } \\
\text { COFINS) }\end{array}$ \\
\hline 2.1) Custos dos produtos, das mercadorias e dos serviços vendidos \\
\hline 2.2) Materiais, energia, serviços de terceiros e outros \\
\hline 2.3) Perda/Recuperação de valores ativos \\
\hline 2.4) Outras (especificar) \\
\hline 3 - VALOR ADICIONADO BRUTO (1 - 2) \\
\hline 4 - DEPRECIAÇÃO, AMORTIZAÇÃO E EXAUSTÃO \\
\hline 5 - VALOR ADICIONADO LÍQUIDO PRODUZIDO PELA ENTIDADE (3 - 4) \\
\hline 6 - VALOR ADICIONADO RECEBIDO EM TRANSFERÊNCIA \\
\hline
\end{tabular}




\begin{tabular}{|l|}
\hline 6.1) Resultado de equivalência patrimonial \\
\hline 6.2) Receitas financeiras \\
\hline 6.3) Outras \\
\hline 7 - VALOR ADICIONADO TOTAL A DISTRIBUIR $(5+6)$ \\
\hline 8 - DISTRIBUIÇÃO DO VALOR ADICIONADO $\left.{ }^{*}\right)$ \\
\hline 8.1) Pessoal \\
\hline 8.1.1 - Remuneração direta \\
\hline 8.1.2 - Benefícios \\
\hline 8.1.3 - FGTS \\
\hline 8.2) Impostos, taxas e contribuições \\
\hline 8.2.1 - Federais \\
\hline 8.2.2 - Estaduais \\
\hline 8.2.3 - Municipais \\
\hline 8.3) Remuneração de capitais de terceiros \\
\hline 8.3.1 - Juros \\
\hline 8.3.2 - Aluguéis \\
\hline 8.3.3 - Outras \\
\hline 8.4) Remuneração de capitais próprios \\
\hline 8.4.1 - Juros sobre o capital próprio \\
\hline 8.4.2 - Dividendos \\
\hline 8.4.3 - Lucros retidos/Prejuízo do exercício \\
\hline 8.4.4 - Participação dos não controladores nos lucros retidos (só para consolidação) \\
\hline
\end{tabular}

Fonte: Pronunciamento Técnico CPC 09 (2011)

De acordo com as instruções apresentadas pelo CPC 09 sobre a elaboração da presente demonstração contábil, no item 1 (Receitas) deverão constar, de forma detalhada, os principais componentes da riqueza criada pela empresa. Devem ser evidenciadas, portanto, as receitas provenientes da venda de mercadorias, produtos e serviços incluindo os valores dos tributos incidentes sobre tais receitas, inclusive quando na demonstração do resultado, tais tributos estejam fora do cômputo dessas receitas.

Dadas as instruções do CPC 09 quanto ao preenchimento do item 1 da DVA, no âmbito das entidades sem fins lucrativos, faz-se necessária uma análise mais detida quanto à origem das receitas obtidas. Considerando que o valor adicionado é obtido, de forma geral, pela diferença entre as vendas e o total dos insumos adquiridos de terceiros, é preciso parcimônia para concluir se as ESFL são, de fato e sempre, geradoras de valor adicionado em virtude da origem de suas receitas. 
Na hipótese de as receitas das entidades serem provenientes exclusivamente de prestação de serviços ou venda de produtos e mercadorias, quando excluídos os insumos consumidos para sua obtenção, não resta dúvida que tais entidades evidenciam valor adicionado bruto positivo.

Por outro lado, muitas são as entidades que financiam suas atividades apenas com recursos de terceiros (setor público e privado), não exercendo qualquer atividade mercantil, caso em que, teoricamente, haveria geração de valor adicionado bruto negativo. Infere-se daí que tais entidades seriam meras gestoras das atividades socioambientais de seus financiadores.

Igualmente é o caso das entidades que são mantidas apenas ou majoritariamente com os resultados provenientes de suas participações societárias ou por meio de rendimentos de aplicações financeiras.

De modo mais complexo, existem entidades sem fins lucrativos que obtém suas receitas de forma mista, isto é, seja com o resultado de venda de produtos, mercadorias e serviços, seja por meio de doações de pessoas físicas e jurídicas, subvenções, receitas de aplicações financeiras e receitas de equivalência patrimonial.

Além das receitas retromencionadas, as entidades deverão fazer constar outras receitas, oriundas, principalmente, de baixas por alienação de ativos não circulantes e outras transações incluídas na demonstração do resultado do exercício que não configuram reconhecimento de transferência à entidade de riqueza criada por terceiros.

Os subitens 1.3 (Receitas relativas à construção de ativos próprios) e 1.4 (Perdas estimadas com créditos de liquidação duvidosa) não apresentam diferenças de tratamento que merecem destaque entre as entidades com ou sem fins lucrativos.

No item 2 (Insumos adquiridos de terceiros) deverá constar o custo dos produtos, mercadorias e dos serviços vendidos, bem como os materiais, energia elétrica, serviços de terceiros e outros, incluindo os tributos incidentes.

Neste item não há que se considerar qualquer diferença de elaboração da DVA das entidades com ou sem fins lucrativos. No entanto, em termos de maior transparência, as entidades do terceiro setor poderiam elaborar suas demonstrações de valor adicionado, por projeto, muito 
frequentes em tais entidades, elaborando, no encerramento de determinado período, a consolidação das demonstrações.

No subitem 2.3 (Perda e recuperação de valores ativos) onde se inclui valores relativos a ajustes por avaliação a valor de mercado dos estoques, imobilizados, investimentos e os valores reconhecidos no resultado do período, tanto na constituição quanto na reversão de provisão para perdas por desvalorização de ativos e no item 4 (Depreciação, amortização e exaustão), igualmente não apresentam maiores divergências de preenchimento em relação às entidades com fins lucrativos.

O principal ponto a ser considerado em estudo comparado entre a elaboração das DVA das entidades com ou sem fins lucrativos reside no item 6 (Valor Adicionado recebido em transferência) que será abordado no capítulo 3.

2.2.1 A contribuição da DVA para o cálculo do PIB e a participação do terceiro setor

A demonstração em estudo utiliza a visão contábil de valor adicionado que, conforme Santos (2007, p. 27) "é a diferença aritmética entre o valor das vendas e os insumos pagos a terceiros mais as depreciações”. Em outras palavras, valor adicionado pode ser definido como "a diferença entre o valor das vendas e o dos consumos intermediários em determinado período" (DE LUCA et al, 2009, p. 25). Por outro lado, sob o ponto de vista macroeconômico, valor adicionado "está intimamente ligado á apuração do produto nacional” (SANTOS, 2007, p. 26).

Nesse sentido, Bêrni e Lautert (2011, p. 97) definem valor adicionado como "a quantidade de valor medido em termos de preços que a sociedade, por meio da utilização do montante de recursos que têm à sua disposição, agregou a um conjunto de recursos previamente existente em uma unidade de tempo" e, ao gerar esse montante de valor agregado, a sociedade mostrase capaz de avaliá-lo sob as óticas do produto, renda e despesa.

O PIB, largamente utilizado como medida de riqueza de uma nação corresponde à soma dos valores adicionados gerados por todos os agentes econômicos do país. Conforme explica De Luca et al. (2009, p. 126), se cada agente econômico do país, inclusive as entidades sem fins lucrativos, calculasse seu próprio valor adicionado, o PIB seria facilmente medido, por meio 
da soma de seus valores, excluídas as duplas contagens dos produtos intermediários que são adquiridos para posterior processamento, fabricação ou revenda. Securato (2011, p. 52) explica que o valor do PIB representa a produção atual de bens finais, de acordo com o preço de mercado.

São três os métodos para se calcular o PIB: sob a ótica da produção, renda e despesa. Pela ótica do produto, o PIB corresponde ao valor bruto (com impostos) da produção de todas as unidades residentes no país, excluídos os produtos intermediários.

Pela ótica da renda o PIB é calculado pela soma de salários, lucros, juros, aluguéis e comissões pagas em cada etapa produtiva ou, nas palavras do IBGE (2012b) o PIB, pelo lado da renda,

É igual a remuneração dos empregados mais o total dos impostos, líquidos de subsídios, sobre a produção e a importação mais o rendimento misto bruto (remuneração recebida pelos proprietários de empresas não constituídas autônomos - que não pode ser identificada separadamente entre capital e trabalho), mais o excedente operacional bruto (saldo resultante do valor adicionado deduzido das remunerações pagas aos empregados, do rendimento misto e dos impostos líquidos de subsídios incidentes sobre a produção).

(IBGE, 2012b, p. 7)

Pela ótica da despesa, considera-se que o dispêndio global da economia é igual ao produto, isto é, corresponde ao total de produtos e serviços finais consumidos.

\footnotetext{
É igual à despesa de consumo das famílias, mais o consumo do governo, mais o consumo das instituições sem fins de lucro a serviço das famílias (consumo final), mais a formação bruta de capital fixo, mais a variação de estoques, mais as exportações de bens e serviços, menos as importações de bens e serviços. Permite a análise de acordo com o destino dos bens e serviços que a economia do País põe à disposição dos usos finais. (IBGE, 2012b, p. 7)
}

Foi em 2002 que o departamento de Estatística da ONU revisou sua metodologia para o cálculo do PIB e reconheceu a importância de se calcular separadamente o valor movimentado pelas entidades sem fins lucrativos, utilizando para abrigar tais valores a chamada Conta Satélite do Terceiro Setor (MEREGE, 2009, p. 10). 
No Brasil, a nova série do Sistema de Contas Nacionais (SCN) do IBGE, publicada em março de 2007, incorporou metodologia de cálculo do consumo de capital fixo pelas Instituições Privadas sem Fins de Lucro, tornando com isso possível estimar seus valores de produção brutos $^{5}$. Na série antiga, os dados das Instituições sem fins lucrativos ao serviço das famílias (ISFL), nome dado ao setor institucional que as abriga, fazia parte do setor Famílias.

De acordo com a Nota Metodológica $n^{\circ} 8$ do Sistema de Contas Nacionais - Referência 2000 do IBGE que trata dos Setores Institucionais, as ISFL "são entidades jurídicas ou sociais criadas com o fim de produzir bens ou serviços, cujo estatuto não lhes permite ser uma fonte de rendimento, lucro ou outro ganho financeiro para as unidades que as criam, controlam ou financiam." (IBGE, 2012)

Securato (2011) explica que a nova metodologia promoveu mudanças substanciais para as estimativas de renda e produção e pela primeira vez, as contas nacionais passaram a contar com os dados da Declaração de Informações Econômico-Fiscais da Pessoa Jurídica (DIPJ).

Estes dados são fornecidos, após análise, pela Secretaria da Receita Federal (SRF), principalmente para as contas de empresas não financeiras. A nova metodologia privilegia também as informações contábeis das empresas, em detrimento de estimativas. (SECURATO, 2011, p. 63).

Instituída pela Instrução Normativa n. 127 de 30/10/1988 a DIPJ deve ser apresentada por todas as pessoas jurídicas inclusive as equiparadas, na forma da legislação pertinente, exceto as microempresas e empresas de pequeno porte - SIMPLES, órgãos públicos, autarquias e fundações públicas, e as pessoas jurídicas inativas, conforme definidas em ato da Secretaria da Receita Federal do Brasil.

As informações a serem prestadas pelas entidades sem fins de lucro imunes e isentas na DIPJ referem-se a seus ativos, passivos, origem e aplicação de recursos, receita de vendas, compra de mercadorias e insumos, custos e despesas com pessoal e serviços prestados por terceiros. A ficha onde se informa as origens e aplicações de recursos tem a estrutura apresentada no quadro a seguir:

\footnotetext{
${ }^{5}$ Disponível em

<ftp://ftp.ibge.gov.br/Contas_Nacionais/Contas_Nacionais_Trimestrais/Notas_Metodologicas/01_apresentacao.p df $>$. Acesso em 20/05/2012.
} 
Quadro 8 - Estrutura da Ficha de Origem e Aplicação de Recursos - DIPJ 2012

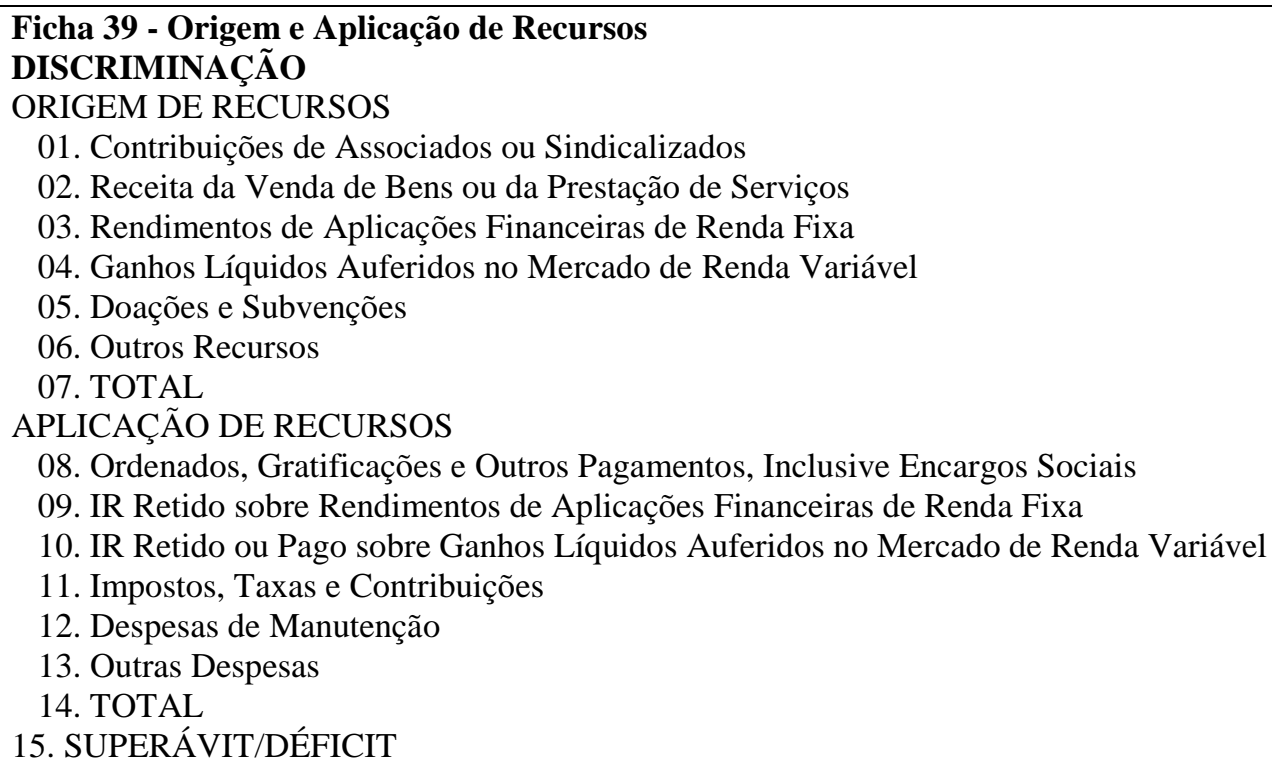

Fonte: Receita Federal (2012)

Em termos de instrução de preenchimento, consta na ajuda do programa DIPJ que a entidade deverá discriminar os valores conforme melhor se enquadrem entre os títulos apresentados, utilizando as linhas 06 (outros recursos) e 13 (outras despesas) somente em casos de impossibilidade de melhor classificação. Ainda, os eventuais empréstimos tomados, devem ser incluídos na linha 05 (Doações e Subvenções) e as amortizações e o pagamento de juros devem ser informados na linha 13 (outras despesas).

De acordo com De Luca et al. (2009), o valor adicionado para fins de cálculo do PIB considerando a nova série do SCN tem como principais componentes a produção e o consumo intermediário.

\footnotetext{
A conta da Produção representa a geração do Valor Adicionado de uma economia que consiste na diferença entre o Valor Bruto da Produção e o Consumo Intermediário, sendo a base para as contas seguintes de geração e distribuição da renda. (DE LUCA et al., 2009, p. 79).
}

Ressaltam as autoras que a produção pode ser mercantil ou não mercantil, sendo considerada mercantil sempre que for trocada ou suscetível de ser trocada no mercado a preços economicamente significativos. Produção não mercantil, explicam, dentre outros são os 
serviços prestados gratuitamente, total ou parcialmente, pelas administrações públicas e instituições privadas sem fins lucrativos à coletividade ou a grupos particulares.

O consumo intermediário representa o valor dos bens e serviços mercantis consumidos ao longo do processo de produção. Não inclui os bens de capital e os serviços ligados à transferência ou instalação de ativos. Para as instituições sem fins lucrativos, o consumo intermediário corresponde à soma dos seus custos e despesas em bens e serviços utilizados durante o processo produtivo (exceto impostos) informados nas pesquisas estruturais do IBGE e nas demais fontes externas (De Luca et al., 2009, p. 83).

Conforme esclarece o Dr. Roberto Luís Olinto Ramos, doutor em Engenharia de Produção e chefe da Coordenação de Contas Nacionais do IBGE entrevistado por Fregonesi (2009, p.157) em sua tese de doutoramento, o valor de produção de uma instituição sem fins de lucro é seu próprio custo de produção, obtido pela soma da remuneração de pessoal e do consumo intermediário.

Assim, quando se pensa em DVA para o terceiro setor como instrumento auxiliar para o cálculo do PIB e considerando sua estrutura e instruções de preenchimento atual, o valor adicionado gerado pelas entidades que o compõem, dependendo do modo de evidenciação das receitas, retornaria um valor adicionado negativo, dado que sob a ótica do IBGE, seu valor de produção é a soma da remuneração de pessoal e do consumo intermediário, que por sua vez, são tratados na referida demonstração como distribuição e diminuição do valor adicionado bruto, respectivamente. 


\section{EVIDENCIAÇÃO DOS RECURSOS DAS ENTIDADES DO TERCEIRO SETOR NA DEMONSTRAÇÃO DO VALOR ADICIONADO}

\subsection{Origens dos Recursos}

Muitas são as possibilidades de as entidades de interesse social obterem recursos para o aparelhamento e mantença de suas atividades. Entre as diversas formas de captação de recursos que podem advir de fontes públicas ou privadas, estão as doações dedutíveis ou não de impostos, os patrocínios, os benefícios tributários (imunidades e isenções) as subvenções, os convênios e parcerias. Olak e Nascimento (2010, p. 27) entendem que as principais fontes de recursos das entidades sem fins lucrativos são basicamente doações, contribuições, subvenções, receitas de aplicações financeiras, receitas de capital, receita de venda de produtos, mercadorias e serviços.

De acordo com o Código Civil, em seu art. 538, "considera-se doação o contrato em que uma pessoa, por liberalidade, transfere do seu patrimônio bens ou vantagens para o de outra”. Ressalte-se que as doações podem ser feitas mediante imposição de certas restrições, temporárias ou permanentes, a critério do doador, trazendo implicações para seu reconhecimento contábil nas entidades agraciadas.

Enquanto a restrição temporária permite à entidade de interesse social gastar ou consumir os ativos doados desde que atendidas às condições impostas, seja pelo tempo decorrido ou por ações da entidade, a restrição permanente é aquela imposta pelo doador que os recursos sejam mantidos permanentemente, permitindo, entretanto, que a entidade gaste ou consuma parte ou todo rendimento derivados de ativos doados.

No que se refere ao benefício fiscal das doações, a legislação do imposto de renda permite a dedutibilidade de valores doados aos fundos dos direitos da criança e do adolescente. As pessoas físicas podem abater até $6 \%$ do valor do imposto de renda devido enquanto às pessoas jurídicas, tributadas pelo lucro real, é permitido o abatimento mensal, trimestral ou anual do imposto de renda devido no limite máximo mensal de $1 \%$ conforme artigo $1^{\circ}$ do Decreto $\mathrm{n}^{\circ}$ 794 de 05 de abril de 1993. 
Outra possibilidade de dedução do imposto devido por pessoas físicas ou jurídicas são os recursos destinados às atividades culturais por meio de doação ou patrocínio. Neste âmbito, abrangido pela Lei Federal de Incentivo à Cultura $n^{\circ}$ 8.313/91, mais conhecida como Lei Rouanet, o conceito operacional de doação é o recurso doado pela pessoa física ou jurídica que não se traduz em publicidade para estas, ao contrário do patrocínio, caso em que a pessoa física ou jurídica busca um incremento de sua imagem.

Para Paes (2006), patrocínio

“[...] é a transferência gratuita, em caráter definitivo, à pessoa física ou jurídica de natureza cultural com ou sem fins lucrativos, de numerário para a realização de projetos culturais, com finalidade promocional e institucional de publicidade" (Paes, 2006, p. 674).

As pessoas físicas podem deduzir $80 \%$ ou $60 \%$ do montante investido ao realizarem doações ou patrocínio, respectivamente, observado o limite de $6 \%$ do imposto devido. Já as pessoas jurídicas podem deduzir $40 \%$ ou $30 \%$ do montante investido ao realizarem doações ou patrocínio, respectivamente, observado o limite de 4\% do imposto devido (BARBOSA; OLIVEIRA, 2011, p. 98).

As contribuições, na visão de Olak e Nascimento (2010) e no contexto do setor em estudo, correspondem a recursos pecuniários oriundos de associados e outros indivíduos ou empresas que se comprometem, periodicamente, a contribuir com determinada quantia, prefixada ou não, para manutenção da entidade ou para a execução de uma obra, um projeto ou atividades específicos.

Outro modo de captação de recursos das entidades de interesse social e de maior expressão são as subvenções que segundo Olak e Nascimento (2010)

\footnotetext{
"compreendem as transferências (ou promessas de transferências) de recursos, derivadas da lei orçamentária e concedidas por órgãos do setor público, ou mesmo por outras organizações privadas, com o objetivo de cobrir despesas com a manutenção e o custeio destas, caracterizadas ou não pela contraprestação de bens e serviços da beneficiária dos recursos" (Olak e Nascimento, 2010, p. 90).
} 
Para pleiteá-las, as entidades sem fins lucrativos devem atender a certos requisitos legais e, uma vez concedidas, essas organizações deverão prestar contas da sua aplicação à unidade concedente.

Paes (2006, p. 681) explica que as subvenções sociais são suplementações da União, Estados, Municípios ou Distrito Federal a empresas e a sociedade de economia mista e entidades privadas sem fins lucrativos que tenham por objeto a prestação de serviços na área de assistência social, saúde e educação.

Em termos de reconhecimento contábil das receitas das entidades sem fins lucrativos, a NBC T 10.19 é taxativa ao determinar que as doações, subvenções e contribuições para custeio, devem ser contabilizadas em contas de receita enquanto que as doações, subvenções e contribuições patrimoniais, inclusive as arrecadadas na constituição da entidade, são contabilizadas no patrimônio social.

Diante das diversas fontes de receitas das entidades sem fins lucrativos, a questão que se busca investigar é se implicariam em diferentes formas de evidenciação na DVA e se, por conseguinte, impactariam no cálculo da participação dessas entidades no PIB.

\subsection{Os investimentos socioambientais na DVA dos investidores conforme tese de Fregonesi}

As empresas, quando fazem investimentos socioambientais, o fazem por diversos motivos: seja para exercer sua visão humanitária dando forma concreta à sua filosofia filantrópica, seja como meio estratégico para impulsionar sua imagem institucional ou ainda, como compensação das externalidades negativas decorrentes do desenvolvimento de suas atividades. No entanto, intui-se que a maior parte das organizações aplica em investimento socioambiental conscientes de sua responsabilidade social.

Apesar da ligação entre o terceiro setor e o investimento social privado ser intuitivamente traduzida como uma manifestação do exercício da responsabilidade social empresarial, importante ressaltar que há outras maneiras de exercê-las. Talvez seja este o motivo para o fato de não existir um consenso sobre a definição de responsabilidade social. Para Goldstein (2007, p. 43) "o conceito de responsabilidade social empresarial é mais multifacetado do que 
pode parecer à primeira vista. As ações voltadas para a comunidade e para o ambiente representam somente duas das várias possibilidades de atuação socialmente responsável de uma organização". Para a autora, a responsabilidade social empresarial deve contemplar também os demais públicos de relacionamento da empresa, como os acionistas, funcionários, clientes, fornecedores e poderes públicos.

Muitas são as teorias que explicam os motivos das práticas de responsabilidade social empresarial. Garriga e Melé apud Fregonesi (2009, p. 23) citam as seguintes: (i) teorias instrumentais com foco no alcance de objetivos econômicos por meio das atividades sociais; (ii) teorias políticas com foco no uso responsável do poder do negócio na arena política; (iii) teorias integrativas com foco na integração das demandas sociais e (iv) teorias éticas com foco na coisa certa para alcançar uma boa sociedade.

Atualmente, as empresas que exercem um papel social, ao elaborarem suas DVAs, alocam os dispêndios relacionados e desde que não se incluam em seu processo produtivo, como despesas, e assim será evidenciado na DRE. Dado que a DVA é elaborada com dados extraídos da DRE, sendo um rearranjo desta porque todas as receitas e despesas que aparecem nesta demonstração estarão somadas também naquela, tais despesas são alocadas como insumos adquiridos de terceiros na DVA na ausência de instruções adicionais sobre como classificá-las.

No entanto, Fregonesi (2009) em sua tese de doutoramento questiona sobre a melhor forma de evidenciação dos investimentos socioambientais na DVA dos investidores. Inicia a pesquisa comparando a publicação da DVA no Brasil com outros países e destaca que uma das diferenças mais relevantes em termos de estrutura adotada pelo Brasil e pouco discutida no meio acadêmico está relacionada a este tipo de investimento. Cita que empresas do Reino Unido, Itália e Singapura, por exemplo, consideram os investimentos socioambientais como distribuição de valor adicionado.

Ressalta que, ainda que o problema de pesquisa inicialmente possa se caracterizar por uma questão puramente normativa sobre qual linha da DVA é mais adequada para classificar os investimentos sociais, elucida que a questão é mais complexa à medida que, a depender de sua classificação, afetará o valor adicionado e, por consequência a contribuição da empresa para a 
produção do país, dado que o produto nacional poderia ser obtido, desde que feitas algumas reconciliações, pela soma dos valores adicionados divulgados na DVA.

A classificação dos investimentos sociais como formação ou distribuição do valor adicionado, segundo Fregonesi, dependerá da avaliação desses investimentos no sentido de investigar se são sacrifícios para geração de receita ou se constituem distribuição de valor adicionado para a comunidade.

A autora salienta a importância de se verificar se o investimento social implica em dispêndio por parte da empresa e qual é a natureza deste dispêndio. Na hipótese de não haver recebimento de produto ou serviço em contrapartida do recurso aplicado, este não pode ser considerado insumo do processo produtivo.

De acordo com a pesquisadora, os investimentos socioambientais poderiam, inicialmente, ser classificados como insumos do processo produtivo, como remuneração dos fatores de produção (capital, terra e trabalho) ou como distribuição secundária da renda (governo) concluindo que os investimentos socioambientais caracterizados como:

(i) Doações não podem ser consideradas insumos do processo produtivo porque não há recebimento de produto ou serviço em contrapartida do recurso e nem como remuneração dos fatores de produção porque não se configura aluguel do serviço do capital, terra ou trabalho. Assim, as doações deveriam ser classificadas como redistribuição da renda gerada e, como governo, aparecer na DVA em distribuição do valor adicionado;

(ii) Investimentos realizados na tentativa de compensar prejuízos previamente causados à sociedade, entende-se que há redução do valor adicionado, pois a empresa estará "pagando" por insumo utilizado no processo produtivo, seja um recurso natural, um bem público ou prejuízos causados a stakeholders;

(iii) Pagamento por produto ou serviço adquirido, é importante observar seu beneficiário final. Sendo a comunidade ou o meio ambiente o beneficiário final, sem contrapartidas destes, o investimento configurar-se-á como redistribuição da renda ou distribuição do valor adicionado. 
No caso em que houver aproveitamento de incentivo fiscal no investimento social, haverá distribuição de valor na DVA, mas no grupo de impostos, taxas e contribuições, não como investimentos socioambientais já que este investimento seria um redirecionamento do imposto devido, e, se não houvesse o investimento social, deveria haver o pagamento do imposto. $\mathrm{Na}$ hipótese desses investimentos não serem classificados nesse grupo - governo, poderá haver distorção no cálculo da carga tributária da empresa, desvirtuando uma das utilidades da DVA.

Ao final, Fregonesi (2009, p. 162) propõe a inclusão de uma linha na DVA para os investimentos socioambientais que atendam às seguintes condições:

- "haver dispêndio por parte da empresa investidora além daqueles gerados pelo próprio processo produtivo, ou, pelo menos, o valor deve ter sido registrado na contabilidade da companhia;

- haver benefício para a comunidade além daqueles proporcionados pela simples existência da empresa;

- o consumo final do bem ou serviço, objeto de investimento social, ocorrer na comunidade;

- o dispêndio não representar compensação de externalidades negativas geradas pelo processo produtivo;

- o dispêndio não representar consumo de bens ou serviços usados no processo produtivo; $e$

- não haver aproveitamento de incentivo fiscal caracterizado como dedução do tributo devido."

Diante das conclusões apresentadas pela autora acima citada, que motivaram a realização do presente estudo, a dúvida que surge é: se os investimentos socioambientais são, em determinadas condições, distribuição de valor adicionado, como as entidades do terceiro setor, que recebem essas transferências de recursos devem evidenciá-las em suas próprias DVAs?

\subsection{A estrutura da DVA conforme modelo do CPC e a composição do valor adicionado das entidades do terceiro setor}


Sabendo que a DVA é, em verdade, um rearranjo da DRE, sendo que todas as contas constantes desta são representadas naquela, importante destacar que quanto maior o nível de detalhamento da natureza das receitas e despesas, além de facilitar a elaboração da DVA, maior será o poder informativo acerca da formação do resultado da entidade com ou sem fins lucrativos.

Nesse sentido, Paes (2006, p. 482) menciona ser altamente conveniente que na elaboração da Demonstração de Superávit ou Déficit, sejam separadas as receitas de serviços prestados, de associados, de contribuições e doações e contratos, entre outras, assim como as despesas, que precisam ser corretamente classificadas, de forma que evidencie, com clareza, a destinação dos recursos.

Dirimindo quaisquer dúvidas acerca da importância da discriminação dos itens que compõem o superávit ou déficit das entidades sem fins lucrativos, Martins (1997, p. 2) recomenda:

\footnotetext{
"[...] se a entidade presta algum tipo de serviço remunerado e ainda recebe doações, contribuições, mensalidades, etc. é altamente conveniente que sejam separadas essas receitas: as provenientes de serviços prestados e as demais recebidas dos associados ou outros; assim como devem ser isolados os custos e as despesas relativos à prestação do serviço remunerado dos outros encargos de manutenção da entidade".
}

Como exposto anteriormente, a estrutura da DVA tem como primeiro item as receitas obtidas pelas empresas por meio da venda de mercadorias, produtos ou pela prestação de serviços. Neste ponto, não há qualquer diferença a ser mencionada quando se compara às receitas obtidas da mesma forma pelas entidades sem fins lucrativos. Ressalte-se que a legislação brasileira não proíbe o exercício de atividades industriais ou comerciais pelas ESFL condicionando, no entanto, que sejam realizadas para o estrito cumprimento das finalidades estatutárias da instituição.

A receita proveniente de contribuições, doações e subvenções, destinadas exclusivamente ao custeio da manutenção da entidade, não apresentariam maiores problemas de alocação na DVA, mais especificamente no grupo 1 - Receitas.

No entanto, os investimentos sociais feitos pelas empresas a título de doação requerem uma análise mais detida quando se coloca em foco, os resultados do estudo de Fregonesi (2009). 
Uma das conclusões alcançadas em sua tese intitulada "Investimentos socioambientais na DVA: formação ou distribuição do valor adicionado?" é a de que as empresas em determinados casos de investimentos socioambientais, realizam distribuição de valor adicionado.

Fregonesi (2009, p. 152) explica que os investimentos socioambientais serão considerados como formação do valor adicionado quando guardarem características de consumo intermediário; caso contrário serão distribuição do valor adicionado.. Assim, a autora afirma que os casos de doação sempre serão distribuição do valor adicionado porque não representam insumos do processo de produção.

Daí se extrai que, teoricamente, as entidades sem fins lucrativos, quando são financiadas apenas por recebimento de transferências de valor adicionado, não geram por si e por sua vez, valor adicionado. Há neste caso, segundo o chefe da Coordenação de Contas Nacionais do IBGE entrevistado por Fregonesi (2009, p. 158) uma redistribuição interna de recursos dentro dos setores não afetando o PIB. Quando uma empresa faz uma doação para uma instituição sem fins de lucro, aumenta a renda disponível dessa entidade e, o uso da renda disponível será consumo e/ou investimentos.

Conclui Fregonesi (2009, p. 158)

\begin{abstract}
"Após estudar os investimentos socioambientais e a remuneração dos fatores de produção sob a ótica conceitual e sob a ótica do IBGE, [...] na DVA, a distribuição de valor adicionado mostra a remuneração dos fatores de produção e a alocação de renda para o governo. [...] A inclusão dos investimentos socioambientais entre as remunerações de fatores da DVA não eliminará a base conceitual por trás da demonstração. Ao contrário, essa categoria de gastos, que vem aumentando sua participação nas empresas, fica mais adequada como distribuição do valor adicionado quando observadas algumas condições.".
\end{abstract}

Assim, se em uma ponta está a empresa que transfere valor adicionado e evidencia tal doação como distribuição de valor adicionado em sua DVA, na outra ponta, em que figuram as entidades sem fins lucrativos, a fim de se alcançar uma congruência de procedimentos, ao receberem doação, deveriam evidenciá-las em suas DVAs, no grupo valor adicionado recebido em transferência. 
No caso dos patrocínios feitos por pessoas jurídicas não há um casamento entre a DVA do patrocinador e do patrocinado. Sob a ótica do patrocinador, por se tratar de um modo de publicidade, em que espera um retorno positivo à sua imagem este dispêndio é considerado, conceitualmente, como remuneração de trabalho e, portanto, insumo adquirido de terceiros. Do ponto de vista do patrocinado tais recursos recebidos seriam alocados no grupo 1 Receitas dado que tal receita seria proveniente da venda de espaço publicitário.

Receitas que igualmente merecem atenção adicional quando o objetivo é sua evidenciação de modo a contribuir para o cálculo da participação das entidades de interesse social no PIB são as provenientes de aplicações financeiras e aquelas resultantes da participação em empresas e empreendimentos. A correta alocação desses recursos seria no grupo 6 - Valor Adicionado Recebido em Transferência, dado que conforme instrui o Pronunciamento Técnico CPC 09, este grupo representa a "riqueza que não tenha sido criada pela própria entidade, e sim por terceiros, e que a ela é transferida, como por exemplo receitas financeiras, de equivalência patrimonial, dividendos, aluguel, royalties, etc." (CPC 09, p. 3).

O segundo grupo da DVA conforme modelo do pronunciamento técnico CPC 09 engloba os insumos adquiridos de terceiros entendidos como os valores relativos às aquisições de matérias-primas, mercadorias, materiais, energia, serviços, etc. que tenham sido transformados em despesas do período. Em termos de especificidades do terceiro setor, é preciso pensar na separação dos insumos consumidos nos projetos daqueles aplicados na manutenção da entidade quando se busca a aplicação de uma boa prática contábil e, sobretudo, em suas consequências, de modo a não desvirtuar a qualidade informacional da demonstração.

Diferente das entidades com fins lucrativos, em que todas as despesas são incorridas como esforço para obtenção de receitas que servem a um único fim, que de modo geral, é o lucro dos acionistas, as ESFL possuem despesas diretamente relacionadas a seus projetos sociais e também aquelas originadas para a manutenção das atividades da entidade, como por exemplo, custos da arrecadação, salários dos funcionários na prestação de serviços, etc.

Logo, ao passo que se busca uma uniformidade de procedimentos para a alocação das receitas das entidades do terceiro setor, conforme sua origem surge um descompasso quando se trata da alocação dos insumos consumidos durante a execução dos projetos sociais por essas 
entidades. Dado que a prática atual implica em alocar todos os gastos da entidade, quer inerentes às suas atividades administrativas, quer inerentes às suas atividades fim como redução do valor adicionado, boa parte das ESFL, financiadas exclusivamente ou principalmente por seus mantenedores, geraria valor adicionado bruto negativo, restando claro que os recursos consumidos não foram gerados por essas entidades.

Assumindo a hipótese de inclusão de uma linha adicional na DVA para os investimentos socioambientais como propõe Fregonesi (2009), o redirecionamento do dispêndio efetuado pela empresa a título de investimento socioambiental, atualmente evidenciado como redução do valor adicionado, para distribuição do valor adicionado, causaria um aumento no valor adicionado.

Se as entidades sem fins lucrativos diante dessa hipótese permanecerem com a prática de reconhecer todos os recursos arrecadados, sem discriminação, como formação do valor adicionado, implicaria em outro aumento de valor adicionado ou uma dupla contagem, onde, na verdade só existe uma transferência de renda entre os setores.

Nesse sentido, De Luca et al. (2009) ao explicarem o valor adicionado recebido em transferência mencionam que apesar de afetar a riqueza da empresa, não representam riqueza gerada por ela, constituindo, pois, um ganho obtido pela aplicação de recursos em outra atividade decorrente da riqueza criada por essa outra atividade, e complementam:

\footnotetext{
Se esse ganho for considerado no cálculo do Valor Adicionado da empresa por ocasião da soma dos valores adicionados de todas as atividades econômicas de determinado período de tempo, realizada pelas contas nacionais para cálculo do PIB, haverá o problema da contagem múltipla. Ou seja, a receita será computada nas duas empresas: na recebedora do ganho (receita de equivalência patrimonial) e na geradora dos resultados. (De Luca et al., 2009, p. 45).
}

Desse modo, para que a proposta de inclusão de linha específica para os investimentos socioambientais de Fregonesi (2009) surta efeitos de modo reflexo na DVA das entidades sem fins lucrativos, resta claro que a DVA para essas entidades necessita de algumas alterações de modo a manter sua qualidade de auxiliar na medição e demonstração da capacidade de geração e distribuição da riqueza de uma entidade. 
Além disso, as ESFL que executam seus projetos utilizando recursos preponderantemente originados de suas mantenedoras atuam em verdade, como executoras da responsabilidade social destas, assumindo o caráter de braços sociais de suas mantenedoras. Assim, a DVA dessas entidades constituídas para esse fim social específico poderia dar maior ênfase nas informações relacionadas à distribuição do valor adicionado que foi gerado por suas mantenedoras, tal qual como uma demonstração contábil complementar da própria mantenedora.

Ao passo que a mantenedora evidenciaria o montante do investimento social como distribuição do valor adicionado, o seu braço social detalharia quantitativamente a aplicação/distribuição do recurso recebido em benefício à sociedade.

Complementarmente, as entidades sem fins lucrativos, nos pedidos de certificação ou renovação do Certificado de Entidade Beneficente de Assistência Social, devem comprovar a aplicação dos recursos arrecadados em gratuidade.

Para entidades cuja atividade preponderante relaciona-se à educação, a gratuidade deve corresponder à razão de $20 \%$ sobre sua receita bruta, entendida como a proveniente da venda de serviços acrescida da receita decorrente de aplicações financeiras, de locação de bens, de venda de bens não integrantes do ativo imobilizado e de doações particulares, cujo montante nunca será inferior à isenção de contribuições sociais usufruídas.

Se a entidade, por sua vez, atua na área da saúde, deverá comprovar anualmente percentual de atendimentos decorrentes de convênio firmado com o Sistema Único de Saúde (SUS), igual ou superior a $60 \%$ do total de sua capacidade instalada.

Retornando à hipótese de a DVA das entidades sem fins lucrativos enfatizarem a aplicação/distribuição do recurso recebido de suas mantenedoras em benefício à sociedade, a comprovação da gratuidade ficaria muito mais visível a todos os interessados nas informações contábeis dessas entidades.

Ressalte-se que a adoção da prática da contabilidade por fundos por entidades do terceiro setor brasileiras minimizaria boa parte dos problemas relacionados não só quanto à elaboração 
da DVA como beneficiaria a transparência na prestação de contas para a sociedade. Nesse sentido, Olak e Nascimento $\left(2010\right.$, p. 119) ressaltam que há várias décadas Martins ${ }^{6}$ já alertava para a necessidade de se utilizar esse sistema de contabilidade para entidades com ativos doados de uso restrito.

De acordo com o AICPA (1994, p. 4) apud Olak e Nascimento (2010),

\begin{abstract}
Contabilidade por Fundos é uma metodologia pela qual os recursos para vários propósitos são classificados, para fins de contabilização e divulgação, de acordo com atividades ou objetivos, conforme especificados pelos doadores, de acordo com as regras, restrições ou limitações impostas aos recursos externos à instituição ou de conformidade com as deliberações dos órgãos diretivos da entidade. (Olak e Nascimento, 2010, p. 128)
\end{abstract}

Nos Estados Unidos, país onde o terceiro setor mais se desenvolveu em virtude de sua cultura política voltada para o associativismo e voluntarismo (Coelho, 2005, p. 21), diante das inconsistências nas práticas contábeis e de divulgação de informações adotadas por instituições sem fins lucrativos levou o Financial Accounting Standards Board (FASB) em conjunto com o Institute of Certified Public Accountants (AICPA) publicarem o FAS n ${ }^{\circ} 117$, que passou a ser obrigatório para estas entidades.

De acordo com Bettiol Jr. e Varella (2006), o FAS 117 apresentou como uma de suas principais inovações a obrigação das entidades sem fins lucrativos elaborarem um conjunto de demonstrações financeiras composto por (a) Relatório de Posição Financeira; (b) Relatório de Atividades; (c) Relatório do Fluxo de Caixa e; (d) Notas Explicativas.

O Relatório de Posição Financeira do FAS 117 conforme os autores, em muito se assemelha ao Balanço Patrimonial elaborado pelas entidades com e sem fins lucrativos no Brasil. Comparando o Balanço Patrimonial utilizado pelas entidades do terceiro setor no Brasil e nos Estados Unidos, o termo Patrimônio Social é substituído por Net Assets (Ativos Líquidos) e este deverá ser composto de pelo menos três classes de contas relacionadas com a característica dos recursos recebidos pela organização, quais sejam, restrito, temporariamente restrito e irrestrito.

\footnotetext{
${ }^{6}$ MARTINS, Eliseu. Demonstrações Contábeis e plano de contas em entidades de fins não lucrativos (I). Boletim IOB - Temática Contábil e Balanços, 22/83, São Paulo, 1983.
} 
Considerando a melhor das hipóteses, de cada fundo representar apenas um projeto, na Demonstração de Superávit/Déficit do Exercício, as ESFL no caso de adotarem a metodologia da contabilidade por fundos, evidenciariam suas despesas conforme as categorias dos fundos e possibilitaria uma maior facilidade para evidenciar a distribuição do valor adicionado gerado e recebido de suas financiadoras.

\subsection{Análise das entidades selecionadas como exemplos}

Neste subcapítulo são trazidas a estudo as entidades de interesse social selecionadas como exemplo, com atividades relacionadas à educação, saúde e assistência social para ilustrar as diferentes formas que empregam para captar recursos. Procura-se, assim, identificar seus modus operandi a fim de inferir se implicam, por consequência, em diferentes modos de evidenciação de suas receitas na DVA, ressalvadas as instruções já constantes no CPC 09 Demonstração do Valor Adicionado.

O objetivo de se adotar tal procedimento é verificar se, caso tais entidades ao elaborarem suas DVAs alocarem todo e qualquer tipo de receita no grupo 1 da demonstração contábil em referência, haveria impacto no cálculo de sua participação no PIB.

Dependendo da origem de recursos das entidades do terceiro setor, a elaboração da DVA não diverge daquelas com fins lucrativos. Logo, a análise das entidades foi separada em três grupos: o primeiro grupo contempla uma ESFL cujas atividades são financiadas com recursos próprios, obtidos por meio da prestação de serviços; no segundo grupo são analisadas as entidades que financiam seus projetos com recursos advindos preponderantemente de suas mantenedoras e; no terceiro grupo estão as entidades cuja origem de recurso é obtida de forma mista.

A seguir, apresenta-se a simulação da DVA das entidades selecionadas como exemplo, incluindo a hipótese de inclusão de uma linha adicional para os investimentos socioambientais feitos pelas empresas e transferidos para as ISFL e conforme instruções emanadas pelo CPC 09 de modo a visualizar seus possíveis reflexos na DVA e sua contribuição para o cálculo do PIB. Foi utilizado para tanto, o conjunto das demonstrações contábeis, inclusive notas explicativas, disponibilizadas em seus sites ou publicadas no Diário Oficial Empresarial de 
São Paulo entre janeiro e abril de 2011. No caso das entidades selecionadas como exemplo terem apresentado sua DVA, esta será comparada com a simulada a fim de se procurar conhecer não só a aderência das instruções do CPC 09, mas, sobretudo, o impacto sobre o valor adicionado.

\subsubsection{GRUPO 1 - Fundação Instituto de Pesquisas Contábeis, Atuariais e Financeiras} (Fipecafi)

A Fipecafi, entidade sem fins lucrativos, criada em 1974 com objetivos fundamentais de (i) prestar serviços e realizar pesquisas que atendam às necessidades dos setores público e privado; (ii) promover cursos, simpósios, seminários, conferências e estudos que visem à melhoria do ensino da Contabilidade, Finanças e Atuária; (iii) promover a divulgação de conhecimentos contábeis, financeiros e atuariais por intermédio de publicações técnicas, periódicos, livros, monografias e outros, obteve em 2010 receitas compostas preponderantemente de venda de serviços relacionados à educação, além de receitas de aluguéis e ganhos na variação de propriedades para investimento. Sua Demonstração de Superávit/Déficit de 2010 evidencia os seguintes itens:

\begin{tabular}{|l|r|}
\hline $\begin{array}{l}\text { Nome da Entidade: FIPECAFI } \\
\text { DEMONSTRAÇÃO DE SUPERÁVIT/DÉFICIT - 2010 }\end{array}$ \\
\hline & (Em Reais) \\
\hline Receita Operacional Líquida & $\mathbf{2 1 . 8 8 8 . 6 3 5}$ \\
\hline & - \\
Custo dos Serviços Prestados & $\mathbf{1 5 . 6 7 2 . 7 7 3}$ \\
\hline Resultado Bruto & $\mathbf{6 . 2 1 5 . 8 6 2}$ \\
\hline (Despesas) Receitas Operacionais & -6.550 .705 \\
\hline Despesas gerais e administrativas & 1.378 .238 \\
\hline Receitas de aluguéis & 1.522 .418 \\
\hline Ganho (perda) na variação de propriedades para investimento & 234.277 \\
\hline Reversão de provisões tributárias & $\mathbf{2 . 8 0 0 . 0 9 0}$ \\
\hline Superávit (déficit) antes das receitas e despesas financeiras & 873.623 \\
\hline Receitas Financeiras & -2.475 .061 \\
\hline Despesas Financeiras & 1.198 .652 \\
\hline Superávit (déficit) do exercício & \\
\hline
\end{tabular}

Considerando a estrutura da DVA nos termos do CPC 09 e suas respectivas instruções de preenchimento, a receita operacional líquida de $\mathrm{R} \$ 21$ milhões, desde que composta apenas de prestação de serviços educacionais, não trariam maiores dificuldades de evidenciação na referida demonstração, isto é, seriam alocadas no grupo 1 - Receitas, bem como o ganho na 
variação de propriedades para investimento no valor de $\mathrm{R} \$ 1.522 .418$ e excluída a complementação da Perda Estimada com Créditos de Liquidação Duvidosa de R \$103.583 conforme nota explicativa $n^{\circ} 07$.

No grupo 2 - Insumos adquiridos de terceiros, a DVA da Fipecafi apresentaria, pelo menos, os valores expressos nas rubricas Custo dos Serviços Prestados de $\mathrm{R} \$ 15.672 .773$ e Despesas Gerais e administrativas de R\$6.550.705 da Demonstração de Superávit/(Déficit), excluídos os valores referentes a gastos com pessoal próprio e eventuais despesas com depreciação, amortização e exaustão, além de outros gastos que conceitualmente são considerados distribuição de valor adicionado e não sua composição.

Na sequência, a Fipecafi evidenciaria em sua DVA, R\$1.378.238 de receita de aluguéis e $\mathrm{R} \$ 873.623$ de receitas financeiras como valores adicionados recebidos em transferência, obtendo, ao final, $\mathrm{R} \$ 2.765 .621$ de valor adicionado total a distribuir.

A distribuição do valor adicionado aos diversos fatores que contribuíram para sua formação depende, sobremaneira, de informações mais detalhadas de cada entidade analisada.

A Fipecafi apresentou em 2010, a seguinte Demonstração do Valor Adicionado:

\begin{tabular}{|l|r|}
\hline $\begin{array}{l}\text { Nome da Entidade: FIPECAFI } \\
\text { DEMONSTRAÇÃO DO VALOR ADICIONADO - 2010 }\end{array}$ \\
\hline & (Em Reais) \\
\hline Receitas & 21.888 .635 \\
\hline Receitas de Serviços & 1.378 .238 \\
\hline Receitas de Aluguéis & 1.522 .418 \\
\hline Ganho (perda) na variação de propriedades para investimento \\
\hline Perdas estimadas em créditos de liquidação duvidosa - \\
\hline Reversão/(Constituição) & 103.583 \\
\hline & \\
\hline Insumos adquiridos de terceiros & -13.670 .582 \\
\hline Despesas dos serviços prestados & -3.797 .894 \\
\hline Materiais, energia, serviços de terceiros e outros & \\
\hline & $\mathbf{7 . 4 2 4 . 3 9 8}$ \\
\hline Valor adicionado bruto & \\
\hline & \\
\hline Depreciação e amortização & \\
\hline & \\
\hline Valor adicionado líquido gerado pela Companhia & \\
\hline & \\
\hline Valor adicionado recebido em transferência & $\mathbf{6 . 8 5 4 . 1 6 6}$ \\
\hline Receitas (despesas) financeiras & \\
\hline & \\
\hline
\end{tabular}




\begin{tabular}{|l|r|}
\hline Valor adicionado total a distribuir & $\mathbf{5 . 2 5 2 . 7 2 8}$ \\
\hline Distribuição do valor adicionado & \\
\hline Empregados & \\
\hline Remuneração direta & 2.241 .200 \\
\hline Benefícios & 617.306 \\
\hline FGTS & 228.111 \\
\hline Tributos & \\
\hline Impostos, taxas e contribuições & 576.325 \\
\hline & \\
\hline Remuneração de capitais de terceiros & \\
\hline Aluguéis & \\
\hline & \\
\hline Remuneração de capitais próprios & \\
\hline Superávit (déficit) do exercício & 1.198 .652 \\
\hline
\end{tabular}

Observam-se na DVA apresentada algumas inconsistências quanto às recomendações do pronunciamento técnico do CPC. As receitas de aluguéis, por exemplo, foram alocadas no grupo 1 quando, teoricamente, deveriam estar evidenciadas como valor adicionado recebido em transferência. Adicionalmente, as receitas financeiras estão agrupadas com as despesas financeiras, sendo esta última, distribuição de valor adicionado como remuneração de capital de terceiros.

Divergências na elaboração da DVA à parte, o foco desta pesquisa é a análise da evidenciação das receitas das entidades sem fins de lucro conforme sua origem. Assim, no caso da Fipecafi, exceto pela alocação das receitas de aluguel, não haveria maiores preocupações quanto à melhor forma de evidenciar suas receitas, dado que são preponderantemente originadas da prestação de serviços educacionais e sobre a efetiva participação desta entidade no produto nacional do país.

\subsubsection{GRUPO 2 - Fundação Bradesco, Fundação Salvador Arena, Fundação Bunge, Instituto} Souza Cruz e Fundação Romi

\section{Fundação Bradesco}

A Fundação Bradesco possui como fonte principal de recursos o resultado de participações societárias. A alocação das receitas dessa entidade na DVA também não apresentaria maiores 
dificuldades e igualmente não suscitaria dúvidas quanto sua evidenciação no grupo 6 da DVA - Valor Adicionado recebido em transferência, assim como instrui o Pronunciamento Técnico CPC 09 - Demonstração do Valor Adicionado.

Muitas são as limitações da simulação da DVA da Fundação Bradesco, visto que apenas publicaram no Diário Oficial Empresarial de São Paulo de 21 de abril de 2011, o balanço patrimonial, a demonstração do superávit do exercício e a demonstração das mutações do patrimônio social, sem notas explicativas. Ainda que diante dessas limitações, a DVA simulada de 2010 da Fundação Bradesco, na hipótese dos investimentos socioambientais serem considerados distribuição do valor adicionado, apresentaria um valor adicionado bruto estimado não superior a $\mathrm{R} \$ 5$ milhões, conforme informações extraídas de sua Demonstração do Superávit do Exercício e assumindo como premissa que as doações de $\mathrm{R} \$ 5.471$ e outras receitas de $\mathrm{R}$ \$14.535 (totalizando $\mathrm{R}$ \$ 20.006) não constituem transferências de investimentos socioambientais de empresas.

\begin{tabular}{|l|r|}
\hline $\begin{array}{l}\text { Nome da Entidade: FUNDAÇÃO BRADESCO } \\
\text { DEMONSTRAÇÃO DE SUPERÁVIT/DÉFICIT - 2010 }\end{array}$ \\
\hline & \multicolumn{1}{|l|}{ (Em Reais mil) } \\
\hline Doações recebidas & $\mathbf{5 . 4 7 1}$ \\
\hline Receitas & $\mathbf{3 . 0 4 4 . 7 7 4}$ \\
\hline Instrumentos Financeiros/Financeiras & 26.679 \\
\hline Resultado de Equivalência Patrimonial & 3.003 .560 \\
\hline Outras & 14.535 \\
\hline Despesas & $\mathbf{2 6 3 . 0 8 2}$ \\
\hline De Educação & 248.872 \\
\hline Outras & 14.210 \\
\hline Superávit líquido do exercício incorporado ao Patrimônio Social & $\mathbf{2 . 7 8 7 . 1 6 3}$ \\
\hline
\end{tabular}

Fonte: Diário Oficial Empresarial de 21/04/2011

\begin{tabular}{|l|r|}
\hline $\begin{array}{l}\text { Nome da Entidade: FUNDAÇÃO BRADESCO } \\
\text { SIMULAÇÃO DA DEMONSTRAÇÃO DO VALOR ADICIONADO - 2010 }\end{array}$ \\
\hline & (Em Reais Mil) \\
\hline Receitas & \\
\hline De doações & 20.006 \\
\hline & \\
\hline Insumos adquiridos de terceiros & -14.210 \\
\hline Outras despesas & \\
\hline & $\mathbf{5 . 7 9 6}$ \\
\hline Valor adicionado bruto & \\
\hline
\end{tabular}


Complementarmente, seria possível inferir que no grupo - Valor Adicionado recebido em transferência, estaria evidenciado os instrumentos financeiros ( $\mathrm{R} \$ 26.679$ mil) e o resultado de equivalência patrimonial ( $\mathrm{R} \$ 3.003 .560 \mathrm{mil})$ resultando em um valor adicionado total a distribuir de $\mathrm{R} \$ 3.036 .035$.

\begin{tabular}{|l|r|}
\hline $\begin{array}{l}\text { Nome da Entidade: FUNDAÇÃO BRADESCO } \\
\text { SIMULAÇÃO DA DEMONSTRAÇÃO DO VALOR ADICIONADO - 2010 }\end{array}$ \\
\hline & (Em Reais Mil) \\
\hline Receitas & \\
\hline De doações & \\
\hline & \\
\hline Insumos adquiridos de terceiros & \\
\hline Outras despesas & -14.210 \\
\hline & \\
\hline Valor adicionado bruto & $\mathbf{5 . 7 9 6}$ \\
\hline & \\
\hline Retenções & \\
\hline & \\
\hline Valor adicionado líquido & $\mathbf{5 . 7 9 6}$ \\
\hline & \\
\hline Valor adicionado recebido em transferência & \\
\hline Instrumentos Financeiros & \\
\hline Resultado de Equivalência Patrimonial & \\
\hline & \\
\hline Valor adicionado total a distribuir & $\mathbf{3 . 0 3 6 . 0 3 5}$ \\
\hline
\end{tabular}

No entanto, no relatório anual de 2010, a Fundação Bradesco, publicou sua DVA elaborada em parte conforme metodologia do Global Reporting Initiative - GRI e, em parte conforme estrutura recomendada pelo CPC 09, onde apresenta na rubrica Valor Adicionado recebido em transferência, um valor incompatível com aqueles constantes de sua Demonstração do Superávit do Exercício.

\begin{tabular}{|c|c|c|}
\hline \multicolumn{2}{|c|}{$\begin{array}{l}\text { Nome da Entidade: FUNDAÇÃO BRADESCO } \\
\text { DEMONSTRATIVO DE VALOR ADICIONADO - } 2010\end{array}$} & \\
\hline Descrição & Explicação & Em R\$ Mil \\
\hline RECEITAS & $\begin{array}{l}\text { Vendas líquidas mais receitas } \\
\text { provenientes de } \\
\text { investimentos } \\
\text { financeiros e venda de ativos. }\end{array}$ & 922.980 \\
\hline
\end{tabular}




\begin{tabular}{|l|l|r|}
\hline Valor econômico distribuído & $\begin{array}{c}\text { Pagamento para fornecedores } \\
\text { investimentos não } \\
\text { estratégicos } \\
\text { e pagamentos de facilitação. }\end{array}$ & 77.453 \\
\hline Salários e benefícios de empregados & $\begin{array}{c}\text { Total da folha de pagamento } \\
\text { para empregados. }\end{array}$ & 168.585 \\
\hline Investimentos na comunidade & $\begin{array}{c}\text { Contribuições voluntárias e } \\
\text { investimento de fundos na } \\
\text { comunidade como um todo, } \\
\text { incluindo doações. }\end{array}$ & \\
\hline $\begin{array}{l}\text { Valor econômico acumulado (valor econômico } \\
\text { gerado menos valor econômico distribuído) }\end{array}$ & $\begin{array}{c}\text { Investimentos e hipotecas } \\
\text { 1 - Insumos adquiridos de terceiros } \\
\text { (inclui ICMS e IPI) }\end{array}$ & 2.830 \\
\hline 1.1 Custos de mercadorias e serviços vendidos & & 13.471 \\
\hline 2 - Valor adicionado bruto & & -85.619 \\
\hline 3 - Retenções & & -85.619 \\
\hline 3.1 Depreciação, Amortização e Exaustão & & -85.619 \\
\hline 4 - Valor Adicionado Líquido produzido pela entidade & & -8.878 \\
\hline 5 - Valor Adicionado recebido em transferência & & -94.497 \\
\hline 6 - Valor Adicionado total a distribuir & & 790.103 \\
\hline 7 - Distribuição do valor adicionado & 695.606 \\
\hline 7.1 Pessoal e Encargos & 695.606 \\
\hline 7.2 Lucros retidos/prejuízo do exercício & 168.585 \\
\hline
\end{tabular}

Fonte: Diário Oficial Empresarial de 21/04/2011

Além do problema relacionado ao modo de evidenciação das receitas das entidades sem fins lucrativos conforme sua origem encontra-se aqui, outro problema, qual seja, as diferentes metodologias empregadas para demonstrar o valor adicionado gerado pelas entidades em questão. Adicionalmente, todas elas apontam como ponto relevante o fornecimento de panoramas úteis para cálculos estatísticos sobre a economia do país.

\section{Fundação Salvador Arena}

A Fundação Salvador Arena, por sua vez, é uma entidade de direito privado, sem fins lucrativos, que tem como finalidade estatutária prestar assistência social, particularmente, em educação, habitação popular e saúde pública, bem como prestar assistência a entidades que 
atuam nessas atividades e amparar e assistir aos empregados da Termomecanica São Paulo S/A e da própria Fundação por meio de auxílios e pensões ${ }^{7}$.

As atividades beneficentes desenvolvidas pela Fundação Salvador Arena, doravante denominada FSA, são financiadas substancialmente por meio dos resultados de sua subsidiária integral Termomecanica São Paulo S/A, além de rendas de locação. Em 2010, apresentou a seguinte demonstração de superávit:

\begin{tabular}{|c|c|}
\hline \multicolumn{2}{|l|}{$\begin{array}{l}\text { Nome da Entidade: FUNDAÇÃO SALVADOR ARENA } \\
\text { DEMONSTRAÇÃO DE SUPERÁVIT/DÉFICIT - } 2010\end{array}$} \\
\hline & (Em Milhares de Reais) \\
\hline \multicolumn{2}{|l|}{ Receitas Operacionais } \\
\hline Equivalência Patrimonial & 135.132 \\
\hline Rendas de Locação & 5.064 \\
\hline \multirow[t]{2}{*}{ Outras } & 921 \\
\hline & 141.117 \\
\hline \multicolumn{2}{|l|}{ Despesas Operacionais } \\
\hline \multicolumn{2}{|l|}{ Educação } \\
\hline Programa Colégio Termomecanica & -13.115 \\
\hline Programa Faculdade de Tecnologia Termomecanica & -7.701 \\
\hline Despesas Gerais e Administrativas & -11.530 \\
\hline Total das despesas com o Centro Educacional & -32.346 \\
\hline \multicolumn{2}{|l|}{ Social } \\
\hline Programa de Apoio a Projetos Sociais & -982 \\
\hline Programa de Auxílio à Alimentação & -744 \\
\hline Programa de Auxílio Emergencial às Famílias & -353 \\
\hline Outros Projetos & -544 \\
\hline Despesas Gerais e Administrativas - Projetos Sociais & -1.604 \\
\hline Total das despesas com a Atividade Social & -4.227 \\
\hline Despesas Gerais e Administrativas & -2.175 \\
\hline Total das Despesas & -38.748 \\
\hline Receitas Financeiras, líqudias & 125.422 \\
\hline Superávit do Exercício & 227.791 \\
\hline
\end{tabular}

Fonte: Diário Oficial Empresarial de São Paulo de 29/04/2011

\footnotetext{
${ }^{7}$ Extraído das Notas Explicativas que acompanham as demonstrações contábeis de 2010, publicadas no Diário Oficial Empresarial de São Paulo em 29/04/2011.
} 
A simulação da Demonstração do Valor Adicionado da FSA, diante das receitas constantes em sua Demonstração do Superávit evidenciaria um valor adicionado bruto negativo. Difícil é a tarefa de separar quanto do resultado de equivalência patrimonial é destinado ao custeio de suas despesas normais e o quanto guarnece o financiamento dos projetos sociais. Resta, portanto, outro ponto crítico na utilidade informacional da DVA para as entidades do terceiro setor e, sobretudo, da necessidade de se promover estudos acadêmicos para questionar se simples adaptações nessa demonstração contábil, como são todas aquelas utilizadas por tais entidades são suficientes para não provocar distorções nos propósitos da referida demonstração.

A DVA simulada da Fundação Salvador Arena é apresentada a seguir:

\begin{tabular}{|c|c|}
\hline \multicolumn{2}{|c|}{$\begin{array}{l}\text { Nome da Entidade: FUNDAÇÃO SALVADOR ARENA } \\
\text { SIMULAÇÃO DA DEMONSTRAÇÃO DO VALOR ADICIONADO - } 2010\end{array}$} \\
\hline & (Em Milhares de Reais) \\
\hline Receitas & - \\
\hline \multicolumn{2}{|l|}{ Insumos adquiridos de terceiros } \\
\hline Despesas gerais e administrativas & -889 \\
\hline Valor adicionado bruto & -889 \\
\hline \multicolumn{2}{|l|}{ Retenções } \\
\hline Depreciação e Amortização & -597 \\
\hline Valor adicionado líquido & -1.486 \\
\hline \multicolumn{2}{|c|}{ Valor adicionado recebido em transferência } \\
\hline Equivalência Patrimonial & 135.132 \\
\hline Rendas de locação & 5.064 \\
\hline Receita financeira & 125.445 \\
\hline Outras & 921 \\
\hline Valor adicionado total a distribuir & 265.076 \\
\hline \multicolumn{2}{|l|}{ Distribuição do valor adicionado } \\
\hline PESSOAL & 535 \\
\hline GOVERNO & 154 \\
\hline \multicolumn{2}{|c|}{ REMUNERAÇÃO DE CAPITAL DE TERCEIROS } \\
\hline Despesas Financeiras & 23 \\
\hline \multicolumn{2}{|l|}{ PROJETOS } \\
\hline Educação & 32.346 \\
\hline Social & 4.227 \\
\hline SUPERÁVIT RETIDO & 227.791 \\
\hline
\end{tabular}


Considerando que as entidades que financiam suas atividades com transferência de valor adicionado gerado por outras entidades, a DVA para as entidades do terceiro setor poderia contemplar um grupo adicional onde seriam alocados os recursos distribuídos à sociedade, o que melhoraria visualmente, o processo de prestação de contas sobre o quanto foi arrecadado e o quanto foi revertido em benefício social.

\section{Fundação Bunge}

A Fundação Bunge cujos objetivos são promover a concessão de prêmios de estímulo à produção intelectual e patrocinar quaisquer outras atividades culturais, assistenciais e socioambientais, divulgou em sua página da internet as demonstrações financeiras relativas ao ano de 2010, incluindo a DVA. Analisando as receitas obtidas pela Fundação Bunge, é possível notar que suas atividades são subsidiadas exclusivamente por empresas do grupo.

Em 2010, a Fundação Bunge apresentou a seguinte demonstração de superávit:

\begin{tabular}{|l|r|}
\hline $\begin{array}{l}\text { Nome da Entidade: FUNDAÇÃO BUNGE } \\
\text { DEMONSTRAÇÃO DE SUPERÁ VIT/DÉFICIT - 2010 }\end{array}$ \\
\hline & \multicolumn{1}{|l|}{ (Em Reais) } \\
\hline Receitas & $9.285 .555,00$ \\
\hline Receitas de Doações & $821.470,28$ \\
\hline Receitas Financeiras & $1.852 .639,66$ \\
\hline Receitas de aluguéis & $\mathbf{1 1 . 9 5 9 . 6 6 4 , 9 4}$ \\
\hline Total & \\
\hline Despesas & $993.599,58$ \\
\hline Prêmio Fundação Bunge & $438.632,98$ \\
\hline Centro de Memória Bunge & $1.570 .232,56$ \\
\hline Comunidade Educativa - Voluntariado & $122.015,53$ \\
\hline Serviços de Terceiros & $763.773,02$ \\
\hline Comunicação & $537.348,85$ \\
\hline Conhecer para Sustentar & $603.941,87$ \\
\hline Comunidade Integrada - Açúcar e Bioenergia \\
\hline Despesas Gerais & \\
\hline Depreciação e Amortização & $446.936,95$ \\
\hline Gastos Administrativos & $590.543,30$ \\
\hline Gastos com Pessoal & $258.238,26$ \\
\hline Despesas Tributárias & $66.746,09$ \\
\hline Despesas Financeiras & $6.477,14$ \\
\hline Total & $\mathbf{6 . 3 9 8 . 4 8 6 , 1 3}$ \\
\hline
\end{tabular}


Superávit do exercício 5.561.178,81

Consta nas notas explicativas que acompanham o conjunto das demonstrações contábeis de 2011 a seguinte origem dos recursos:

\begin{tabular}{|l|c|c|}
\hline Empresa Doadora & Valor 2011 & Valor 2010 \\
\hline Bunge Alimentos & $\mathrm{R} \$ 2.266 .008,00$ & $\mathrm{R} \$ 1.792 .395,00$ \\
\hline Bunge Fertilizantes & $\mathrm{R} \$ 2.095 .092,00$ & $\mathrm{R} \$ 1.642 .230,00$ \\
\hline Fertimport & $\mathrm{R} \$ 624.900,00$ & $\mathrm{R} \$ 555.930,00$ \\
\hline Sub-total & $\mathbf{R} \$ \mathbf{4 . 9 8 6 . 0 0 0 , 0 0}$ & $\mathbf{R} \mathbf{3 . 9 9 0 . 5 5 5 , 0 0}$ \\
\hline Pedro Afonso Açúcar e Bioenergia & $\mathrm{R} \$ 250.000,00$ & - \\
\hline Bunge Philanthropic Foundation & - & $\mathrm{R} \$ 5.295 .000,00$ \\
\hline Total & $\mathbf{R} \$ \mathbf{5 . 2 3 6 . 0 0 0 , 0 0}$ & $\mathbf{R} \mathbf{9 . 2 8 5 . 5 5 5 , 0 0}$ \\
\hline
\end{tabular}

Assim, considerando a essência das transações realizadas entre as empresas componentes do grupo, é possível inferir que há uma transferência de valor adicionado produzido por outras empresas que não a Fundação, responsável somente por desenvolver projetos socioambientais em nome do grupo.

Entretanto, a DVA publicada pela Fundação Bunge evidencia o montante das doações de seus mantenedores como receitas de doações, no grupo 1 e como valor adicionado recebido em transferência as receitas financeiras e de aluguel.

\begin{tabular}{|c|c|}
\hline \multicolumn{2}{|c|}{$\begin{array}{l}\text { Nome da Entidade: FUNDAÇÃO BUNGE } \\
\text { DEMONSTRAÇÃO DO VALOR ADICIONADO - } 2010\end{array}$} \\
\hline & (Em Reais) \\
\hline \multicolumn{2}{|l|}{ Receitas } \\
\hline Receitas de doações & $9.285 .555,00$ \\
\hline \multicolumn{2}{|l|}{ Insumos adquiridos de terceiros } \\
\hline Materiais, energia, serviços de terceiros e outros & $-4.050 .976,20$ \\
\hline Valor adicionado bruto & $5.234 .578,80$ \\
\hline Depreciação e Amortização & $-446.936,95$ \\
\hline Valor adicionado líquido gerado pela entidade & 4.787.641,85 \\
\hline \multicolumn{2}{|l|}{ Valor adicionado recebido em transferência } \\
\hline Receitas financeiras & $821.470,28$ \\
\hline Receitas de aluguéis & $1.852 .639,66$ \\
\hline Valor adicionado total a distribuir & 7.461.751,79 \\
\hline Distribuição do valor adicionado & 7.461.751,79 \\
\hline Empregados & 1.148.471,64 \\
\hline
\end{tabular}




\begin{tabular}{|l|r|} 
Remuneração direta & $912.116,31$ \\
\hline Benefícios & $161.735,63$ \\
\hline FGTS & $74.619,70$ \\
\hline Tributos & $\mathbf{3 3 3 . 3 2 8 , 1 0}$ \\
\hline Impostos, taxas e contribuições & $333.328,10$ \\
\hline INSS & $245.394,66$ \\
\hline PIS s/ folha de pagamento & $8.801,29$ \\
\hline IRRF s/ aplicações financeiras e IOF & $66.746,09$ \\
\hline IPTU & $12.238,13$ \\
\hline Impostos e taxas & 147,93 \\
\hline Remuneração de capitais de terceiros & $\mathbf{4 1 8 . 7 7 3 , 2 4}$ \\
\hline Juros e outras financeiras & $6.477,14$ \\
\hline Aluguéis & $412.296,10$ \\
\hline Remuneração de capitais próprios & $\mathbf{5 . 5 6 1 . 1 7 8 , 8 1}$ \\
\hline Superávit do exercício & $5.561 .178,81$ \\
\hline
\end{tabular}

\begin{tabular}{|c|c|}
\hline \multicolumn{2}{|c|}{$\begin{array}{l}\text { Nome da Entidade: FUNDAÇÃO BUNGE } \\
\text { SIMULAÇÃ̃O DA DEMONSTRAÇÃO DO VALOR ADICIONADO - } \\
2010\end{array}$} \\
\hline & (Em Reais) \\
\hline \multicolumn{2}{|l|}{ Receitas } \\
\hline Receitas de doações & - \\
\hline \multicolumn{2}{|l|}{ Insumos adquiridos de terceiros } \\
\hline Materiais, energia, serviços de terceiros e outros & $-1.502 .668,73$ \\
\hline Valor adicionado bruto & $-1.502 .668,73$ \\
\hline Depreciação e Amortização & $-446.936,95$ \\
\hline Valor adicionado líquido gerado pela entidade & $-1.949 .605,68$ \\
\hline \multicolumn{2}{|l|}{ Valor adicionado recebido em transferência } \\
\hline Doações dos Mantenedores & $9.285 .555,00$ \\
\hline Receitas financeiras & $821.470,28$ \\
\hline Receitas de aluguéis & $1.852 .639,66$ \\
\hline Valor adicionado total a distribuir & $10.010 .059,26$ \\
\hline \multicolumn{2}{|l|}{ Distribuição do valor adicionado } \\
\hline Empregados & 258.238,26 \\
\hline Tributos & 66.746,09 \\
\hline Remuneração de capitais de terceiros & 418.773,24 \\
\hline PROJETOS & $3.705 .122,86$ \\
\hline Remuneração de capitais próprios & 5.561.178,81 \\
\hline
\end{tabular}

As diferenças que se apresentam entre o valor adicionado bruto na DVA publicada pela Fundação Bunge em relação à DVA simulada referem-se, em primeiro lugar quanto à realocação das receitas de doação para o grupo 6 - Valor adicionado recebido em transferência. 
Em segundo lugar, os gastos relacionados aos projetos desenvolvidos pela Fundação Bunge (Prêmio Fundação Bunge, Comunidade Educativa - Voluntariado, Conhecer para Sustentar e Comunidade Integrada - Açúcar e Bioenergia) foram redirecionados para distribuição de valor adicionado, na rubrica Projetos, dado que não se enquadram no conceito de insumos adquiridos de terceiros, qual seja, "bens e serviços consumidos no processo de produção $e$ geração de receitas" (SANTOS, 2007, p. 49).

Ainda, foi considerado como distribuição de valor adicionado aos empregados e ao governo, o valor constante na DRE publicada (gastos com pessoal no valor de $\mathrm{R} \$ 258.238,26$ e despesas tributárias no valor de $\mathrm{R} \$ 66.746,09)$, que se mostra divergente do valor apresentado na DVA publicada ( $\mathrm{R} \$ 912.116,31$ e $\mathrm{R} \$ 333.328,10$ respectivamente).

\section{$\underline{\text { Instituto Souza Cruz }}$}

O Instituto Souza Cruz, associação civil de natureza educacional e cultural, sem fins lucrativos, e qualificada como OSCIP, foi fundada em 2000 com o objetivo de promover ações sócio-educacionais e culturais que contribuam para o desenvolvimento sustentável do cidadão brasileiro.

As fontes de recursos para o custeio do Instituto provêm de doações, substancialmente da Souza Cruz S/A. Anualmente, o instituto obtém o compromisso da sua mantenedora de custear seu orçamento operacional.

\begin{tabular}{|l|r|}
\hline $\begin{array}{l}\text { Nome da Entidade: INSTITUTO SOUZA CRUZ } \\
\text { DEMONSTRAÇÃO DE SUPERÁVIT - 2010 }\end{array}$ \\
\hline & (Em Milhares de Reais) \\
\hline Receitas Operacionais & 3.840 \\
\hline De doação & 558 \\
\hline Financeiras & 3.235 \\
\hline Despesas Operacionais & 680 \\
\hline Com Projetos & 1 \\
\hline Gerais & $\mathbf{4 8 2}$ \\
\hline Financeiras & \\
\hline Superávit do exercício & \\
\hline
\end{tabular}


Como se pode observar na demonstração de superávit de 2010 do Instituto Souza Cruz, toda doação, que conforme notas explicativas são substancialmente originadas de sua mantenedora Souza Cruz S/A, seriam evidenciadas na DVA conforme instruções de preenchimento emitidas pelo CPC 09, isto é, como formação do valor adicionado (grupo 1 - Receitas). No caso de inclusão de uma linha específica na DVA para os investimentos socioambientais feitos pelas empresas, a Souza Cruz evidenciaria a doação como valor adicionado recebido em transferência e o Instituto Souza Cruz, por sua vez, alocaria essa transferência no grupo 6 - Valor Adicionado recebido em transferência. A DVA simulada apresentaria a seguinte composição:

\begin{tabular}{|c|c|}
\hline $\begin{array}{l}\text { Nome da Entidade: INSTITUTO SOUZA CRUZ } \\
\text { SIMULAÇÃO DA DEMONSTRAÇÃO DO VALO }\end{array}$ & \\
\hline & (Em Milhares de Reais) \\
\hline Receitas & - \\
\hline Insumos adquiridos de terceiros & \\
\hline Gerais & -680 \\
\hline Valor adicionado bruto & -680 \\
\hline Retenções & - \\
\hline Valor adicionado líquido & -680 \\
\hline Valor adicionado recebido em transferência & \\
\hline Doações & 3.840 \\
\hline Financeiras & 558 \\
\hline Valor adicionado total a distribuir & 3.718 \\
\hline Distribuição do valor adicionado & \\
\hline PESSOAL & - \\
\hline REMUNERAÇÃO DE CAPITAL DE TERCEIROS & 1 \\
\hline PROJETOS & 3.235 \\
\hline SUPERÁVIT RETIDO & 482 \\
\hline
\end{tabular}

\section{Fundação Romi}

A Fundação Romi é uma entidade beneficente de assistência social, declarada de utilidade pública federal, estadual e municipal, registrada no Conselho Nacional de Assistência Social cujo objetivo estatutário consiste em assistir a população carente, em situação de vulnerabilidade e riscos, especialmente crianças e adolescentes, a fim de preservar seus 
direitos fundamentais, satisfazer suas necessidades básicas e desenvolver integralmente suas potencialidades cidadãs.

O resultado superavitário de 2010 é apresentado a seguir:

\begin{tabular}{|c|c|}
\hline \multicolumn{2}{|l|}{$\begin{array}{l}\text { Nome da Entidade: FUNDAÇÃO ROMI } \\
\text { DEMONSTRAÇÃO DE SUPERÁVIT - } 2010\end{array}$} \\
\hline & (Em Reais) \\
\hline \multicolumn{2}{|l|}{ Receitas } \\
\hline Doações da mantenedora & 481.994 \\
\hline Receitas financeiras & 3.663 .779 \\
\hline Outras doações & 23.307 \\
\hline Outras receitas & 2.455 \\
\hline \multicolumn{2}{|l|}{ Despesas } \\
\hline \multicolumn{2}{|l|}{ Proteção Social Básica: } \\
\hline \multicolumn{2}{|l|}{ Serviço de convivênvia e fortalecimento de vínculos: } \\
\hline \multicolumn{2}{|c|}{ Programa Integrado de Desenvolvimento Humano e Social - PRODHES: } \\
\hline Centro de Vivências do Desenvolvimento Infantil - CEDIN & -272.482 \\
\hline Núcleo de Educação Integrada - NEI & -1.394 .667 \\
\hline Meu Amigo da Escola Pública & -163 \\
\hline Abelhas Ocupadas & -36.754 \\
\hline Encontro de Educadores & -27.264 \\
\hline Gestão para o Sucesso Escolar & -2.947 \\
\hline Sistematização do Processo de Avaliação de Impacto Social & -137.581 \\
\hline LEP - Logo na Escola Pública & -58.574 \\
\hline Programa de Bolsa Auxílio & -151.828 \\
\hline Centro de Documentação Histórica - CEDOC & -762.316 \\
\hline Estação Cultural & -333.622 \\
\hline \multicolumn{2}{|l|}{ Defesa e Garantia de Direitos: } \\
\hline IDI - UM & -10.499 \\
\hline \multicolumn{2}{|l|}{ Outras Despesas: } \\
\hline Outras despesas diversas & -7.922 \\
\hline Total & -3.196 .619 \\
\hline Superávit operacional & 974.916 \\
\hline \multicolumn{2}{|l|}{ Outros Resultados } \\
\hline Despesas Financeiras & -2.312 \\
\hline Resultado na alienação de bens do ativo imobilizado & -686 \\
\hline Superávit do exercício & 971.918 \\
\hline
\end{tabular}




\begin{tabular}{|c|c|}
\hline \multicolumn{2}{|c|}{$\begin{array}{l}\text { Nome da Entidade: FUNDAÇÃO ROMI } \\
\text { SIMULAÇÃO DA DEMONSTRAÇÃO DO VALOR ADICIONADO - } 2010\end{array}$} \\
\hline & (Em Reais) \\
\hline \multicolumn{2}{|l|}{ Receitas } \\
\hline Outras receitas & 1.769 \\
\hline \multicolumn{2}{|l|}{ Insumos adquiridos de terceiros } \\
\hline Materiais, energia, serviços de terceiros e outros & -7.922 \\
\hline Valor adicionado bruto & -6.153 \\
\hline \multicolumn{2}{|l|}{ Depreciação e Amortização } \\
\hline Valor adicionado líquido gerado pela entidade & -6.153 \\
\hline \multicolumn{2}{|l|}{ Valor adicionado recebido em transferência } \\
\hline Doações dos Mantenedores & 505.301 \\
\hline Receitas financeiras & 3.663 .779 \\
\hline Valor adicionado total a distribuir & 4.162.927 \\
\hline \multicolumn{2}{|l|}{ Distribuição do valor adicionado } \\
\hline Empregados & - \\
\hline Tributos & - \\
\hline Remuneração de capitais de terceiros & 2.312 \\
\hline PROJETOS & 3.188 .697 \\
\hline Remuneração de capitais próprios & 971.918 \\
\hline
\end{tabular}

A simulação da DVA da Fundação Romi, aplicados os conceitos operacionais extraídos da tese de Fregonesi, permitiria as seguintes considerações:

* No grupo Receitas seriam alocadas as outras receitas e excluído o resultado negativo na alienação de bens do ativo imobilizado, totalizando um montante de $\mathrm{R} \$ 1.769$.

* No grupo Valor Adicionado recebido em transferência estariam alocadas as doações da mantenedora no montante de $\mathrm{R} \$ 481.994$, as outras doações no valor de $\mathrm{R} \$ 23.307$ e as receitas financeiras de $\mathrm{R} \$ 3.663 .779$ totalizado $\mathrm{R} \$ 4.169 .080$..

* As despesas relacionadas aos projetos seriam, em verdade, distribuição de valor adicionado gerado por outras entidades. Serviriam essas entidades meras intermediadoras na distribuição de renda recebida de suas mantenedoras.

Pelo fato das atividades dessas entidades serem financiadas em sua maior parte ou exclusivamente com valores adicionados recebidos em transferência, a Fundação Bradesco, Fundação Salvador Arena, Fundação Bunge e Instituto Souza Cruz, teoricamente, não teriam 
sua participação computada no PIB do terceiro setor uma vez que o IBGE utiliza para o cálculo do PIB a soma dos valores adicionados brutos.

Assim ocorre com grande parte das Fundações e Institutos que são braços das empresas interessadas em incrementar sua responsabilidade social. Paes (2006) denomina tais entidades de fundações empresariais ou corporativas. Segundo o citado autor a instituição de uma fundação é a forma encontrada pelas empresas para que estas enquadrem sua vontade de efetivamente ajudar a sociedade em que se insere, por meio da realização de tarefas ou prestação de benefícios concretos, imediatos e individualizados. Salienta, ainda, que

A atuação desse tipo de fundação vem trazer mais eficiência e maximização
na resolução dos graves problemas sociais brasileiros e, é fato notório terem
essas fundações instituídas por empresa, as fundações empresariais ou
corporativas, uma práxis administrativa em que predomina a nacionalidade
instrumental/estratégica, ou seja, predominam as ações orientadas para o
alcance das finalidades por meio da maximização dos recursos disponíveis (PAES, 2006, p. 219).

3.4.3 GRUPO 3 - Instituto Ayrton Senna, Fundação Abrinq pelos direitos da criança e do adolescente, Instituto Avon e Fundação Orsa

\section{Instituto Ayrton Senna}

Ao contrário dos exemplos retromencionados, o Instituto Ayrton Senna tem suas receitas compostas de forma mista. O Instituto Ayrton Senna (IAS) é uma entidade de assistência social, constituída em 1994 sob a forma de associação civil de caráter filantrópico e tem por objeto a promoção e o desenvolvimento de projetos culturais, científicos, artísticos, educacionais, sociais, esportivos, beneficentes, de pesquisa e assistenciais.

Em 13 de julho de 1998 o IAS foi declarado como instituição de utilidade pública em âmbito federal, estando, portanto, imune aos impostos incidentes sobre o seu patrimônio, sua renda e seus serviços conforme garante o artigo 150, inciso VI, alínea "c" da Constituição Federal. O IAS também está isento das contribuições para a seguridade social, por força do disposto no parágrafo $7^{\circ}$ do artigo 195 da Constituição Federal. 
Adicionalmente, o IAS foi declarado, também de utilidade pública estadual e municipal, por meio dos Decretos n. 44.149/99, de 28 de julho de 1999 e do Decreto n. 36.675, de 27 de dezembro de 1996, respectivamente.

As fontes de recursos que sustentam suas atividades têm como origem parcerias realizadas com empresas públicas e privadas, além de doações, contribuições recebidas de contratos de sublicença de uso da marca Senna, da imagem do piloto Ayrton Senna, dos direitos autorais sobre o logotipo do IAS, dos personagens que compõem a Turma do Senninha, bem como da arte aplicada no capacete e da assinatura estilizada do piloto Ayrton Senna, cujos direitos foram cedidos, sem ônus, pela empresa Ayrton Senna Empreendimentos Ltda., sem qualquer oposição da família de Ayrton Senna.

Suas receitas, em 2010 estão compostas da seguinte forma (em R \$):

\begin{tabular}{|l|r|}
\cline { 2 - 2 } \multicolumn{1}{c|}{} & \multicolumn{1}{c|}{ Em R\$ } \\
\hline (1) Contratos de sublicença & 16.993 .568 \\
\hline (2) Doações, contribuições e outros & 9.860 .485 \\
\hline (3) Parcerias estratégicas & 9.683 .499 \\
\hline (4) Receitas Financeiras & 6.378 .110 \\
\hline
\end{tabular}

Enquanto as receitas provenientes dos contratos de sublicença seriam mais adequadamente evidenciadas no grupo 1 da DVA, dado que é produto da exploração de um ativo próprio, seria necessário um exame mais atento das receitas constantes no item (2) Doações, contribuições e outros e (3) Parcerias estratégicas para fins de elaboração da DVA, tendo em vista sua contribuição na composição do PIB. Caso o item (2) esteja composto de doações socioambientais recebidas de pessoas jurídicas, o IAS deveria evidenciar tal doação no grupo 6 - Valor Adicionado Recebido em Transferência para, em consonância com os resultados da tese de doutoramento de Fregonesi (2009), resultar em melhores contribuições ao cálculo do PIB nas duas pontas, isto é, tanto das empresas que estão distribuindo valor adicionado quanto aquelas contempladas pelas transferências de valor adicionado.

O IAS no item (2) engloba doações de competência dos exercícios conforme "Termo de Aliança” que são celebrados tanto com o poder público como com instituições privadas. Um exemplo desses últimos é o denominado LIDE-EDH (Líderes Empresariais - Empresários 
para o Desenvolvimento Humano), grupo de líderes empresariais de organizações de origem, porte e setores bastante distintos.

De acordo com as notas explicativas do IAS, no item (3) estariam alocadas as receitas provenientes de contratos com o poder público, mais especificamente com o Fundo Nacional de Desenvolvimento da Educação - FNDE, do Ministério da Educação.

Importante ressaltar as diferenças de nomenclaturas entre contratos, convênios e parcerias possíveis de serem estabelecidas entre entidades sem fins lucrativos e o poder público. Barbosa e Oliveira (2011) elucidam que enquanto o termo contrato "designa genericamente o acordo entre duas ou mais pessoas que transferem entre si algum direito ou se sujeitam a alguma obrigação, bem como designa o documento resultante desse acordo" no termo convênio "quer-se ressaltar que as partes convenentes têm um interesse comum e não interesses opostos, como ocorre na típica relação contratual”. Finalizam a conceituação explicando que a expressão termo de parceria "designa, de modo mais específico, a relação que se estabelece entre o poder público e as entidades sem fins lucrativos qualificadas como OSCIP's - organizações da sociedade civil de interesse público”.

Coelho (2005) em seu estudo comparado sobre as entidades do terceiro setor do Brasil e dos Estados Unidos, comenta sobre a avaliação dos processos de parceria. Nos países que costumam firmá-lo com frequência (Holanda, Canadá e EUA), "tanto os governos como as organizações, têm pouco interesse em divulgar resultados, pois eles desnudam suas próprias falhas e podem gerar cobranças de seus constituintes, doadores e membros" (Coelho, 2005).

Da análise do Instituto Ayrton Senna extrai-se que os recursos provenientes do setor público e privado são aglutinados em uma mesma linha da demonstração do superávit/déficit impossibilitando dessa maneira a evidenciação das transferências de investimentos socioambientais promovidos pelo setor privado. Além disso, a transparência quanto aos recursos públicos recebidos e o controle sobre sua efetiva aplicação em benefícios sociais restam igualmente prejudicados.

Fundação Abrinq pelos Direitos da Criança e do Adolescente 
A Fundação Abrinq, elabora diversos programas e projetos voltados para o interesse de crianças e adolescentes. A análise de suas demonstrações contábeis e informações disponíveis em seu site na Internet possibilita qualquer cidadão interessado conhecer o modo como conduz suas atividades. Por exemplo, nas demonstrações contábeis de 2010 e nas informações constantes em sua página na internet é possível conhecer todos os programas em andamento, como são financiados e quais são os seus objetivos. Por outro lado, não é possível visualizar quanto do valor arrecadado por cada programa foi convertido em benefício às crianças e adolescentes.

A título de ilustração, pode-se citar o Programa Nossas Crianças. Neste projeto, pessoas físicas e jurídicas contribuem financeiramente com a Fundação Abrinq que, por sua vez, repassa recursos para organizações sociais que entregam às crianças e adolescentes serviços ou benefícios supostamente de qualidade.

Outro programa conduzido pela Fundação Abrinq é o Empresa Amiga da Criança. Neste programa, as pessoas jurídicas contribuem mensalmente considerando um percentual sobre seus faturamentos e o montante arrecadado serve para a manutenção das atividades da Fundação. Em 2010, o referido programa arrecadou $\mathrm{R} \$ 810.434$. As empresas participantes desse programa adquirem o direito de utilizar um selo, evidenciando sua participação no programa. Conforme resultados da pesquisa de Fregonesi (2009), os investimentos socioambientais que proporcionam benefícios em termos de publicidade positiva às empresas não devem ser consideradas como distribuição de valor adicionado e sim como insumos adquiridos de terceiros, isto é, como se fossem um investimento feito pela empresa quando contrata serviços de terceiros.

Neste caso, em particular, enquanto a empresa participante deste programa evidenciaria em sua DVA uma redução do valor adicionado - insumo adquirido de terceiro, a ESFL, por outro lado evidenciaria tal valor recebido como Receita de Contribuições/Doações, sendo este recurso considerado como formação de valor adicionado da entidade, dado que foi obtido como um rendimento de um ativo próprio.

A demonstração do superávit da Fundação Abrinq em 2010 é apresentada a seguir: 


\begin{tabular}{|l|r|}
\hline $\begin{array}{l}\text { Nome da Entidade: FUNDAÇÃO ABRINQ } \\
\text { DEMONSTRAÇÃO DE SUPERÁVIT - 2010 }\end{array}$ \\
\hline & (Em Reais) \\
\hline Receitas das atividades & 4.418 .608 \\
\hline Projetos & 2.118 .089 \\
\hline Contribuições Programa Nossas Crianças & 4.705 .207 \\
\hline Contribuições e Mensalidades & 1.029 .134 \\
\hline Financeiras & 95.312 \\
\hline Doações de ativo intangível & $\mathbf{1 2 . 3 6 6 . 3 5 0}$ \\
\hline Total & \\
\hline Despesas das atividades & -4.418 .608 \\
\hline Projetos & -2.118 .089 \\
\hline Contribuições Programa Nossas Crianças & -4.399 .869 \\
\hline Gerais e Administrativas & -135.313 \\
\hline Depreciações, amortizações e baixas de ativo imobilizado \\
\hline Financeiras & -3.754 \\
\hline & - \\
\hline Total & $\mathbf{1 1 . 0 7 5 . 6 3 3}$ \\
\hline Superávit do exercício & \\
\hline
\end{tabular}

Na página eletrônica da Fundação Abrinq é possível verificar que dispõe de vários canais para captação de recursos, tais como doações mensais ou esporádicas para custeio das despesas de funcionamento da fundação, doações para projetos específicos, venda de produtos, parcerias com empresas dos mais variados ramos.

Interessante notar que conforme consta na demonstração de superávit acima, o total das receitas reconhecidas e discriminadas nas rubricas 'Projetos' (R $\$ 4.418 .608)$ e 'Contribuições Programa Nossas Crianças' ( $\mathrm{R} \$ 2.118 .089$ ) que totalizam $\mathrm{R} \$ 6.536 .697$, equivale ao montante das despesas discriminadas nas mesmas rubricas. Mencionam ainda, em nota explicativa, a natureza dessas despesas: dos $\mathrm{R} \$ 6,5$ milhões arrecadados, $\mathrm{R} \$ 2.284 .132$ foram repassados a entidades sendo o restante, salários e encargos ( $\mathrm{R} \$ 1.642 .577)$, despesas administrativas ( $\mathrm{R} \$ 1.104 .298)$, viagens e estadas ( $\mathrm{R} \$ 585.925)$, marketing ( $\mathrm{R} \$ 377.420)$ e eventos (R $\$ 290.143)$.

Assumindo a premissa de que as contribuições e mensalidades no valor de $\mathrm{R} \$ 4.705 .207$ são receitas geradas pela entidade, a simulação do valor adicionado gerado pela entidade elaborada com observância às informações constantes nas notas explicativas seria: 


\begin{tabular}{|c|c|}
\hline \multicolumn{2}{|c|}{$\begin{array}{l}\text { Nome da Entidade: FUNDAÇÃO ABRINQ } \\
\text { SIMULAÇÃO DA DEMONSTRAÇÃO DO VALOR ADICIONADO - } 2010\end{array}$} \\
\hline & (Em Reais) \\
\hline \multicolumn{2}{|l|}{ Receitas } \\
\hline De Contribuições e Mensalidades & 4.705 .207 \\
\hline \multicolumn{2}{|l|}{ Insumos adquiridos de terceiros } \\
\hline Serviços prestados pessoa jurídica & -467.022 \\
\hline Marketing e distribuição & -911.106 \\
\hline Material de uso e consumo & -222.140 \\
\hline Viagens e estadias & -218.059 \\
\hline Água, luz e telefone & -205.313 \\
\hline Outras despesas & -106.135 \\
\hline Valor adicionado bruto gerado pela entidade & 2.575 .432 \\
\hline \multicolumn{2}{|l|}{ Retenções } \\
\hline Depreciação & -135.313 \\
\hline Valor adicionado líquido gerado pela entidade & 2.440 .119 \\
\hline \multicolumn{2}{|l|}{ Valor adicionado recebido em transferência } \\
\hline Projetos & 4.418 .608 \\
\hline Contribuições Programa Nossas Crianças & 2.118 .089 \\
\hline Financeiras & 1.029 .134 \\
\hline Doações de ativos intangíveis & 95.312 \\
\hline Valor adicionado total a distribuir & 10.101 .262 \\
\hline \multicolumn{2}{|l|}{ Distribuição do valor adicionado } \\
\hline PESSOAL & 1.642 .577 \\
\hline GOVERNO & 193.026 \\
\hline \multicolumn{2}{|l|}{ REMUNERAÇÃO DE CAPITAL DE TERCEIROS } \\
\hline Aluguel e despesas financeiras & 438.245 \\
\hline PROJETOS & $6.536,697$ \\
\hline CONTRIBUIÇÃO PROGRAMA NOSSAS CRIANÇAS & 2.118 .089 \\
\hline SUPERÁVIT RETIDO & 1.290 .717 \\
\hline
\end{tabular}

Dado que o valor de produção de uma instituição sem fins de lucro é obtido pela soma da remuneração de pessoal e do consumo intermediário e o IBGE utiliza como fonte de dados a DIPJ, os valores adicionados estimados obtidos na simulação da DVA comparados às informações da DIPJ apresentam inconsistências. 


\begin{tabular}{|ll|}
\hline Ficha 39 - Origem e Aplicação de Recursos & \\
DISCRIMINAÇÃO & \\
ORIGEM DE RECURSOS & 4.705 .207 \\
01. Contribuições de Associados ou Sindicalizados & \\
02. Receita da Venda de Bens ou da Prestação de Serviços & 1.029 .134 \\
03. Rendimentos de Aplicações Financeiras de Renda Fixa & \\
04. Ganhos Líquidos Auferidos no Mercado de Renda Variável & 6.536 .697 \\
05. Doações e Subvenções & 95.312 \\
06. Outros Recursos & 12.366 .350 \\
07. TOTAL & \\
APLICAÇÃo DE RECURSOS & 1.642 .577 \\
08. Ordenados, Gratificações e Outros Pagamentos, Inclusive Encargos Sociais & \\
09. IR Retido sobre Rendimentos de Aplicações Financeiras de Renda Fixa & \\
10. IR Retido ou Pago sobre Ganhos Líquidos Auferidos no Mercado de Renda Variável & 193.026 \\
11. Impostos, Taxas e Contribuições & 2.703 .333 \\
12. Despesas de Manutenção & 6.536 .697 \\
13. Outras Despesas & 11.075 .633 \\
14. TOTAL & 1.290 .717 \\
\hline
\end{tabular}

$\underline{\text { Instituto Avon }}$

O Instituto Avon é uma associação civil de direito privado, sem fins lucrativos, constituída em 2003 pela Avon Cosméticos Ltda., sua mantenedora, e tem por finalidade promover a saúde e o bem-estar da mulher por meio da mobilização da sociedade.

\begin{tabular}{|l|r|}
\hline $\begin{array}{l}\text { Nome da Entidade: INSTITUTO AVON } \\
\text { DEMONSTRAÇÃO DE SUPERÁVIT - 2010 }\end{array}$ \\
\hline & (Em Reais) \\
\hline Receita das atividades & 9.863 .145 \\
\hline Receitas de doações & 213.186 \\
\hline Receitas financeiras & \\
\hline Despesas das atividades & 7.634 .854 \\
\hline Despesas com relações públicas & 39.640 \\
\hline Despesas com serviços & 249.848 \\
\hline Despesas de comunicação & 247.940 \\
\hline Despesas institucionais & 461 \\
\hline Despesas financeiras & 15.153 \\
\hline Despesas com taxas e contribuições & 3.859 \\
\hline Despesas de depreciação & $\mathbf{1 . 8 8 4 . 5 7 6}$ \\
\hline Superávit do exercício & \\
\hline
\end{tabular}

Conforme se verifica na demonstração do superávit de 2010 do Instituto Avon, entidade qualificada como OSCIP, sua DVA simulada não evidenciaria receitas próprias. Em visita a 
sua página na internet, consta que seus recursos financeiros são disponibilizados pela Avon, de modo que esta coloque em prática seu investimento social. "A verba é arrecadada a partir de $7 \%$ do valor da venda de alguns produtos Avon. Os produtos que apoiam a causa são sempre alternados entre cremes, batons, perfumes etc. para que o consumidor possa contribuir constantemente ${ }^{\prime \prime}{ }^{8}$. Consta nas notas explicativas que em 2010, o montante recebido de pessoa física totalizou $\mathrm{R} \$ 3.507$ e que, neste ano, foram recebidos reembolsos de despesas de doação efetuada em 2007 da Fundação Ary Frauzino no valor de R\$53.775, tendo sido considerado como receita de doação. Presume-se que, o restante tenha sido transferência de valor adicionado gerado por sua mantenedora, totalizando $\mathrm{R} \$ 9.805 .863$.

Adicionalmente, extrai-se de suas notas explicativas que os custos e despesas operacionais são segregados das despesas administrativas, informação não disponível nas demais entidades analisadas. No entanto, existe uma diferença no montante de $\mathrm{R} \$ 11.000$ nas despesas institucionais evidenciadas na demonstração do superávit em relação às constantes das notas explicativas.

Assumindo como premissa que as doações das pessoas físicas são direcionadas ao custeio das atividades administrativas da entidade e as demais são financiadoras dos projetos, o valor adicionado bruto apresentaria negativo em $\mathrm{R} \$ 533.921$.

\begin{tabular}{|l|r|}
\hline $\begin{array}{l}\text { Nome da Entidade: INSTITUTO AVON } \\
\text { SIMULAÇÃO DA DEMONSTRAÇÃO DO VALOR ADICIONADO - 2010 }\end{array}$ \\
\hline & (Em Reais) \\
\hline Receitas & 3.507 \\
\hline Doações de pessoas físicas & 39.640 \\
\hline Insumos adquiridos de terceiros & 249.848 \\
\hline Despesas com serviços & 247.940 \\
\hline Despesas de comunicação & $\mathbf{5 3 3 . 9 2 1}$ \\
\hline Despesas institucionais & \\
\hline Valor adicionado bruto gerado pela entidade & 3.859 \\
\hline Retenções & $\mathbf{5 3 7 . 7 8 0}$ \\
\hline Encargos com depreciação & \\
\hline Valor adicionado líquido gerado pela entidade & 9.859 .638 \\
\hline Valor adicionado recebido em transferência & 213.186 \\
\hline Receitas de doações & $\mathbf{9 . 5 3 5 . 0 4 4}$ \\
\hline Receitas financeiras & \\
\hline Valor adicionado total a distribuir & \\
\hline
\end{tabular}

\footnotetext{
${ }^{8}$ Informação constante no site do Instituto Avon. Disponível em <http://www.institutoavon.org.br/quem-somosrecursos-financeiros/>. Acesso em 13/07/2012.
} 


\begin{tabular}{|l|r|} 
Distribuição do valor adicionado & 9.535 .044 \\
\hline PESSOAL & - \\
\hline GOVERNO & 15.153 \\
\hline REMUNERAÇÃO DE CAPITAL DE TERCEIROS & 461 \\
\hline PROJETOS & 7.634 .854 \\
\hline SUPERÁVIT RETIDO & 1.884 .576 \\
\hline
\end{tabular}

\section{Fundação Orsa}

A Fundação Orsa é uma entidade de assistência social, sem fins lucrativos, constituída em abril de 1994 e se dedica a assistir crianças e adolescentes em suas necessidades familiares e sociais, especialmente educação, saúde, assistência social e geração de riquezas, desenvolvendo projetos próprios e em parcerias.

\begin{tabular}{|l|r|}
\hline $\begin{array}{l}\text { Nome da Entidade: FUNDAÇÃO ORSA } \\
\text { DEMONSTRAÇÃO DE SUPERÁVIT - 2010 }\end{array}$ \\
\hline & (Em Reais) \\
\hline Receita de colaborações & 8.844 .951 \\
\hline Em moeda corrente & - \\
\hline Em materiais & \\
\hline (Despesas) Receitas operacionais & -1.168 .583 \\
\hline Despesas & -7.290 .469 \\
\hline Próprias & -437.210 \\
\hline Com Projetos & -27.685 \\
\hline Doações e subvenções para terceiros & 663.417 \\
\hline Impostos e contribuições & -198.033 \\
\hline Isenção da quota patronal - INSS & -3.849 \\
\hline Reversão/(constituição) de provisão para contingências \\
\hline Outras despesas & $\mathbf{3 8 2 . 5 3 9}$ \\
\hline Superávit operacional antes do resultado financeiro \\
\hline Resultado financeiro & -13.903 \\
\hline Despesas financeiras & 5.579 \\
\hline Receitas financeiras & $\mathbf{3 7 4 . 2 1 5}$ \\
\hline Superávit do exercício & \\
\hline
\end{tabular}

A receita de colaborações da Fundação Orsa se compõe de subvenções (R $\$ 2.019 .984$ ) e doações de empresas integrantes do Grupo Orsa (R \$6.824.967) conforme notas explicativas. 
Dado que as receitas recebidas das mantenedoras são transferências de valor adicionado gerado por estas, e as subvenções?

O setor institucional que representa as atividades do governo é denominado administração pública, e segundo o IBGE,

[...] é constituído por unidades que têm como função principal produzir serviços não-mercantis destinados à coletividade e/ou efetuar operações de repartição de renda e de patrimônio. Os serviços são considerados nãomercantis quando prestados a preços economicamente não significativos. A principal fonte de recursos do setor é o pagamento obrigatório efetuado pelas demais unidades institucionais na forma de impostos, taxas e contribuições sociais.

As unidades administrativas do setor efetuam três tipos diferentes de despesas finais: [...] despesas com transferência para outras instituições ou famílias com objetivo de distribuir renda, promover o desenvolvimento regional e assegurar a prestação adequada de serviços de saúde e educação. O governo exerce, na maioria dos órgãos dos três poderes, o papel de agente de transferência. [...] (grifo nosso) (IBGE, 2012c).

Assim, as subvenções, bem como os auxílios e contribuições são transferências voluntárias de recursos públicos, oriundos do orçamento da União e deveriam também ser reconhecidos na DVA das entidades do terceiro setor, como transferência de valor adicionado. Neste caso, a DVA poderia proporcionar um maior controle dos recursos destinados pelo governo às entidades sem fins lucrativos e sua aplicação. 


\section{CONSIDERAÇÕES FINAIS}

Na busca por uma conclusão acerca da utilidade da DVA para as entidades do terceiro setor tendo em vista as diferentes fontes de recursos possíveis a estas entidades, e sua consequente utilidade no cálculo da participação do setor no produto nacional, o presente estudo percorreu diversas etapas.

Primeiramente foram analisadas as principais características do terceiro setor e suas diversas fontes de recursos.

Em seguida, foram abordados os conceitos operacionais da Demonstração do Valor Adicionado e como as entidades com fins lucrativos evidenciam seus investimentos socioambientais em suas DVAs.

$\mathrm{Na}$ sequência, foi realizada uma simulação das DVAs das entidades do terceiro setor selecionadas como exemplos, aplicando de modo reflexo nessas entidades as conclusões da tese de doutoramento de Fregonesi (2009) que considera que as doações das empresas, em determinadas condições são distribuição de valor adicionado.

A análise das demonstrações de superávit/déficit das entidades selecionadas neste estudo proporcionou uma ideia da distinção da estrutura de financiamento do terceiro setor. Do resultado dessa análise a fim de conhecer suas diversas fontes de receitas e possíveis tratamentos diferentes para efeito de elaboração de suas demonstrações de valor adicionado, conclui-se que as entidades que mantêm suas atividades e financia seus projetos com recursos advindos da prestação de serviços ou venda de mercadorias ou produtos, geram por si valor adicionado, contribuindo na participação do setor no produto nacional, dado que o PIB poderia ser obtido pela soma dos valores adicionados brutos da DVA, salvo algumas reconciliações.

Diferente é a situação das fundações e institutos empresariais que assumem um papel (e o risco) de meras gestoras dos recursos recebidos de suas mantenedoras quando estas procuram dar forma concreta à sua responsabilidade social. Neste caso, por financiarem sua manutenção 
e atividades fim com valores adicionados gerados e recebidos de suas mantenedoras, não há geração de valor adicionado próprio por parte dessas entidades, não causando impacto no cômputo do PIB por se tratar de redistribuições secundárias de renda.

Conclusão similar poderia ser aplicada às entidades sem fins lucrativos cujas atividades são financiadas majoritariamente por recursos advindos do governo via transferências voluntárias como subvenções, auxílios e contribuições. Neste caso, se uma estrutura diferenciada de DVA fosse construída para o terceiro setor, onde os recursos recebidos em transferência fossem destacados por setor (público e privado) haveria uma melhora no nível de informação do quanto dos recursos arrecadados pelo governo via impostos e transferidos para essas entidades, são revertidos, de fato, para a sociedade, seja em benefícios para a saúde, educação, assistência social ou meio ambiente, a depender dos propósitos das entidades.

Ressalte-se que o terceiro setor é regido por legislação esparsa, e as entidades que o compõem, quando buscam transparência em sua prestação de contas, o fazem à sua maneira e conveniência. Não há, por exemplo, em termos de práticas contábeis, uniformidade de procedimentos quanto ao nível de detalhamento das demonstrações contábeis, diferente dos Estados Unidos, onde o FAS 117 é obrigatório para as entidades do terceiro setor. Outro ponto que se pode destacar são as diversas metodologias para elaboração de relatórios sociais que permitem que as empresas que os elaboram evidenciem apenas informações convenientes.

Para que a demonstração do valor adicionado, para as entidades sem fins lucrativos, assuma efetivamente o papel de instrumento de transparência e auxilie o cálculo do produto nacional, são necessárias não só meras adaptações como ocorre nas demais demonstrações contábeis, sobretudo quanto à proposta de inclusão de linha específica para os investimentos socioambientais de Fregonesi (2009). Para que sua proposta surta efeitos de modo reflexo na DVA das entidades sem fins lucrativos, sem desvirtuar seu auxílio no cálculo do PIB, resta claro que a DVA para essas entidades necessita de algumas alterações.

Isso implica em maiores esforços do meio acadêmico a fim de analisar qual o impacto de eventuais mudanças na estrutura dessa demonstração analisando os diversos tipos de entidades que compõem o terceiro setor que, por contribuírem para o desenvolvimento sustentável do país, são merecedoras de maior atenção. 


\section{REFERÊNCIAS}

ACIOLI, Andréa. A explosão das ONGS no mundo e no Brasil e seus reflexos no espaço rural fluminense. $4^{\mathbf{0}}$ Encontro Nacional de Grupos de Pesquisas - ENGRUP, São Paulo, pp. 825, 2008. Disponível em <http://w3.ufsm.br/gpet/engrup/ivengrup/pdf/acioli_a.pdf>. Acesso em $16 / 07 / 2012$.

ALVES, Cássia Vanessa Olak. Organizações da sociedade civil de interesse público e termos de parceria: um estudo sobre o processo de avaliação de resultados dos projetos sociais desenvolvidos com recursos governamentais no Brasil. 2005. Dissertação (Mestrado em Controladoria e Contabilidade) - Faculdade de Economia, Administração e Contabilidade da Universidade de São Paulo, São Paulo.

BARBOSA, Maria Nazaré Lins; OLIVEIRA, Carolina Felippe de. Manual de ONGs: guia prático de orientação jurídica. Coord.: Luiz Carlos Merege. 5. ed. - Rio de Janeiro : Editora FGV, 2011.

BÊRNI, Duilio de Avila; LAUTERT, Vladimir (Org.). Mesoeconomia: lições de contabilidade social: a mensuração do esforço produtivo da sociedade. Porto Alegre : Bookman, 2011.

BETTIOL JR., Alcides. Formação e destinação do resultado em entidades do terceiro setor: um estudo de caso. São Paulo, 2005. Dissertação (Mestrado em Ciências Contábeis) Programa de Pós-Graduação em Ciências Contábeis, Departamento de Contabilidade e Atuária, Faculdade de Economia, Administração e Contabilidade da Universidade de São Paulo.

; VARELLA, Patrícia Siqueira. Demonstrações contábeis para instituições do Terceiro Setor: um estudo do Statement of Financial Accounting Standards $\mathrm{n}^{\circ} 117$ (FAS 117). Congresso USP. 2006.

BRASIL. Constituição da República (1988). Disponível em <http://www.planalto.gov.br/ccivil_03/constituicao/constitui\%C3\%A7ao.htm>. Acesso em 05/12/2011.

BRASIL. Decreto-Lei n. 7.568, de 16/09/2011. Diário Oficial - República Federativa do Brasil: Poder Executivo. Brasília, DF, 2011.

BRASIL. Lei 10.406, de 10/01/2002. Diário Oficial - República Federativa do Brasil: Poder Executivo. Brasília, DF, 2002. 
BRASIL. Ministério da Fazenda. Receita Federal. DIPJ - Declaração de Informações Econômico-fiscais da Pessoa Jurídica. 2012.

BULGARIN, Maria Clara Cavalcante et al. Caderno de procedimentos aplicáveis à prestação de contas das entidades do terceiro setor (fundações). 2. ed. Brasília: Fundação Brasileira de Contabilidade, 2012.

COELHO, Simone de Castro Tavares. Terceiro Setor: um estudo comparado entre Brasil e Estados Unidos. 2. ed. São Paulo : SENAC, 2002.

COMITÊ DE PRONUNCIAMENTOS CONTÁBEIS - CPC. CPC 09 - Demonstração do Valor Adicionado. 2011. Disponível em < http://cpc.org.br/pdf/CPC_09.pdf $>$. Acesso em 02/11/2011.

CONSELHO FEDERAL DE CONTABILIDADE - CFC. Manual de procedimentos contábeis e prestação de contas das entidades de interesse social. 2. ed. Brasília, 2008.

CONSELHO FEDERAL DE CONTABILIDADE - CFC. Resolução CFC no 837/99. Disponível em < http://www.cfc.org.br>. Acesso em 01/10/2011.

CONSELHO FEDERAL DE CONTABILIDADE - CFC. Resolução CFC no 852/99. Disponível em < http://www.cfc.org.br>. Acesso em 01/10/2011.

CONSELHO FEDERAL DE CONTABILIDADE - CFC. Resolução CFC no 966/03. Disponível em < http://www.cfc.org.br>. Acesso em 01/10/2011.

CONTROLADORIA GERAL DA UNIÃO - CGU. Portal da Transparência do governo federal. Transferências de recursos por favorecido (entidades sem fins lucrativos). Disponível

em: <http://www.portaltransparencia.gov.br/PortalTransparenciaPesquisaFavorecido.asp?hidIdTip oFavorecido $=2 \&$ hidNumCodigoTipoNaturezaJuridica $=3 \&$ Exercicio=2010\#>. Acesso em $31 / 08 / 2011$.

DE LUCA, Márcia martins Mendes; CUNHA, Jacqueline Veneroso Alves da; RIBEIRO, Maísa de Souza; OLIVEIRA, Marcelle Colares. Demonstração do valor adicionado: do cálculo da riqueza criada pela empresa ao valor do PIB. 2. ed. São Paulo : Atlas, 2009.

DIAS, Maria Tereza Fonseca. Terceiro setor e Estado: legitimidade e regulação: por um novo marco jurídico. Belo Horizonte : Fórum, 2008.

FALCONER, Andres Pablo. A promessa do terceiro setor: Um Estudo sobre a Construção do Papel das Organizações Sem Fins Lucrativos e do seu Campo de Gestão. Disponível em: <http://lasociedadcivil.org/docs/ciberteca/andres_falconer.pdf>. Acesso em 07.10.2011. 
FREGONESI, Mariana Simões Ferraz do Amaral. Investimentos socioambientais na demonstração do valor adicionado: formação ou distribuição do valor adicionado? São Paulo, 2009. Tese (Doutorado em Controladoria e Contabilidade) - Programa de PósGraduação em Controladoria e Contabilidade, Departamento de Contabilidade e Atuária, Faculdade de Economia, Administração e Contabilidade da Universidade de São Paulo.

IOSCHPE, Evelyn et al. $3^{\circ}$ Setor: desenvolvimento social sustentado. Rio de Janeiro : Paz e Terra, 2005.

GLOBAL REPORTING INICIATIVE. Diretrizes para Relatório de Sustentabilidade 20002006a. Disponível em: < https://www.globalreporting.org/resourcelibrary/brazil-portugueseg3-economic-indicator-protocols.pdf>. Acesso em 16/01/2012.

GLOBAL REPORTING INICIATIVE. Protocolo de Indicadores Econômicos 2000-2006b.

Disponível em: <https://www.globalreporting.org/resourcelibrary/Brazil-Portuguese-G3-

Economic-Indicator-Protocols.pdf>. Acesso em 16/01/2012.

GOLDSTEIN, Ilana Seltzer. Responsabilidade Social: das grandes corporações ao terceiro setor. São Paulo : Ática, 2007.

GRUPO DE INSTITUTOS, FUNDAÇÕES E EMPRESAS - GIFE. Censo GIFE 2009-2010. Disponível em <www.gife.org.br>. Acesso em 15/10/2011.

INSTITUTO BRASILEIRO DE GEOGRAFIA E ESTATÍSTICA - IBGE. As fundações privadas e associações sem fins lucrativos no Brasil - 2005. Disponível em <http://www.ibge.gov.br/home/estatistica/economia/fasfil/2005/default.shtm>. Acesso em $31 / 08 / 2011$.

INSTITUTO BRASILEIRO DE GEOGRAFIA E ESTATÍSTICA.. Sistema de contas nacionais. 2. ed. - Rio de Janeiro: IBGE, 2008.

INSTITUTO BRASILEIRO DE GEOGRAFIA E ESTATÍSTICA.. Em 2008, PIB atinge R\$ 3 trilhões e cresce 5,2\%. Disponível em: $<$ http://www.ibge.gov.br/home/presidencia/noticias/noticia_visualiza.php?id_noticia=1746\&i d_pagina=1>. Acesso em 20/01/2012.

INSTITUTO DE PESQUISA ECONÔMICA APLICADA.. Valor Econômico (SP): Regras usam propostas da CPI das ONGs. Disponível em < http://www.ipea.gov.br/portal/index.php?option=com_content\&view=article\&id=11159\&Ite mid=75>. Acesso em 05/12/2011.

IUDÍCIBUS, Sergio de. Teoria da contabilidade. 8. ed. - São Paulo: Atlas, 2006.

LOPES, Alexsandro Broedel; MARTINS, Eliseu. Teoria da contabilidade: uma nova abordagem. São Paulo : Atlas, 2007. 
MARTINS, Eliseu. Contabilidade de entidades sem fins lucrativos não governamentais. Boletim IOB - Temática Contábil e Balanços. Bol.12/97, São Paulo, 1997.

MARTINS, Gilberto de Andrade; THEÓPHILO, Carlos Renato. Metodologia da investigação científica para ciências sociais aplicadas. 2. ed. São Paulo : Atlas, 2009.

MEREGE, Luiz Carlos. Censo do Terceiro Setor. Disponível em: < http://www.fundacaosalvadorarena.org.br/download/relatorio_analitico_2009.pdf>. Acesso em $05 / 12 / 2011$.

MILANI FILHO, Marco Antonio Figueiredo. A função controladoria em entidades filantrópicas: uma contribuição para a avaliação de desempenho. São Paulo, 2004. 140p. Dissertação (Mestrado), Faculdade de Economia, Administração e Contabilidade da Universidade de São Paulo. Disponível em:<www.fea.usp.br>. Acesso em 15/05/2012.

NAKAGAWA, Masayuki. Estudos de alguns aspectos de controladoria que contribuem para a eficácia gerencial. Tese de doutorado. Faculdade de Economia, Administração e Contabilidade da Universidade de São Paulo, 1987.

ORDEM DOS ADVOGADOS DO BRASIL - OAB. Cartilha terceiro setor. Disponível em <http://www.abong.org.br/final/download/cartilhaoab2007.pdf>. Acesso em 10/11/2011.

OLAK, Paulo Arnaldo; NASCIMENTO, Diogo Toledo do. Contabilidade para entidades sem fins lucrativos (Terceiro setor) - 3. ed. - São Paulo : Atlas, 2010.

OLIVEIRA, José Antônio Puppim de. Uma avaliação dos balanços sociais das 500 maiores. In: RAE Eletrônica, v. 4, n. 1, Art. 2, jan./jul. 2005. Disponível em <http://www.scielo.br/pdf/raeel/v4n1/v4n1a02.pdf >. Acesso em 15 de janeiro de 2012.

PAES, José Eduardo Sabo. Fundações, associações e entidades de interesse social: aspectos jurídicos, administrativos, contábeis, trabalhistas e tributários. 6. ed. - Brasília : Brasília Jurídica, 2006.

SANTOS, Ariovaldo dos. Demonstração do Valor Adicionado: como elaborar e analisar a DVA. 2. ed. São Paulo : Atlas, 2007.

; CARVALHO, L. Nelson. DVA, uma forma de avaliar a criação de riqueza. Revista Exame. São Paulo, p. 132-133, Set. 1997. Anuário Melhores e Maiores.

SANTOS, Boaventura de Sousa. A reinvenção solidária e participativa do Estado. In: PEREIRA, Luiz Carlos Bresser; WILHEIM, Jorge; SOLA, Lourdes (Org.). Sociedade e Estado em transformação. São Paulo : UNESP; Brasília : ENAP, 1999. 
SECURATO, José Cláudio. Economia brasileira: história, conceitos e atualidades. 2. ed. São Paulo : Saint Paul Editora, 2011.

SZAZI, Eduardo. Terceiro Setor: regulação no Brasil. 4. ed. São Paulo: Peirópolis, 2006.

TACHIZAWA, Takeshy. Organizações não governamentais e Terceiro setor: criação de ONGs e estratégias de atuação. São Paulo : Atlas, 2002.

TINOCO, João Eduardo Prudêncio. Balanço social e o relatório da sustentabilidade. São Paulo : Atlas, 2010.

VIEIRA, Patricia dos Santos. Verdades e mitos na interpretação da demonstração do valor adicionado. São Paulo, 2010. Dissertação (Mestrado em Controladoria e Contabilidade) - Programa de Pós-Graduação em Ciências Contábeis, Departamento de Contabilidade e Atuária, Faculdade de Economia, Administração e Contabilidade da Universidade de São Paulo.

ZARPELON, Sandra Regina. A esquerda não socialista e o novo socialismo utópico: aproximações entre a atuação das ONGs e o cooperativismo da CUT. Dissertação (mestrado) - Instituto de Filosofia e Ciências Humanas, Universidade Estadual de Campinas, 2003. Disponível em <http://www.unicamp.br/cemarx/Disserata\%E7\%E3o.Sandra.pdf >. Acesso em 14/01/2012. 


\section{APÊNDICE}

\section{APÊNDICE 1 - ENTIDADES ASSOCIADAS AO GIFE NO PERÍODO DE 2009 E 2010}

\begin{tabular}{|c|c|c|c|}
\hline 1 & 141 Soho Square Comunicação & 48 & Fundação Santillana \\
\hline 2 & 3M do Brasil & 49 & Fundação Semear \\
\hline 3 & ACES - Ação Comunitária do Espírito Santo & 50 & Fundação Telefônica \\
\hline 4 & AES Brasil & 51 & Fundação Tide Setubal \\
\hline 5 & Aldeias Infantis SOS Brasil & 52 & Fundação Vale \\
\hline 6 & Amanco Brasil & 53 & Fundação Victor Civita \\
\hline 7 & Associação Sequoia Foundation & 54 & Fundação Volkswagen \\
\hline 8 & Banco Bradesco & 55 & Fundação W.K. Kellogg \\
\hline 9 & BASF & 56 & Fundación Avina \\
\hline 10 & BorgWarner Brasil & 57 & Fundo Cristão para Crianças \\
\hline 11 & Braskem & 58 & Gerdau \\
\hline 12 & Bridgestone Firestone do Brasil & 59 & Goodyear do Brasil \\
\hline 13 & BRQ Soluções em Informática & 60 & Grupo ABC de Comunicação \\
\hline 14 & Carrefour & 61 & Grupo BrasilCred \\
\hline 15 & CCR - Companhia de Concessões Rodoviárias & 62 & Harald Indústria e Comércio de Alimentos \\
\hline 16 & Citigroup & 63 & IAMAR - Instituto Alair Martins \\
\hline 17 & Comgás - Companhia de Gás de São Paulo & 64 & IBM Brasil \\
\hline 18 & Fersol Indústria e Comércio & 65 & Impaes - Instituto Minidi Pedroso de Arte e Educação Social \\
\hline 19 & Fundação Abrinq pelos Direitos da Criança & 66 & Instituto Alana \\
\hline 20 & Fundação Alphaville & 67 & Instituto Algar \\
\hline 21 & Fundação Ana Lima & 68 & Instituto Arcor Brasil \\
\hline 22 & Fundação ArcelorMittal Acesita & 69 & Instituto Avon \\
\hline 23 & Fundação ArcelorMittal Brasil & 70 & Instituto Ayrton Senna \\
\hline 24 & Fundação Banco do Brasil & 71 & Instituto BM\&F Bovespa \\
\hline 25 & Fundação Bradesco & 72 & Instituto C\&A de Desenvolvimento Social \\
\hline 26 & Fundação Bunge & 73 & Instituto Camargo Corrêa \\
\hline 27 & Fundação Cargill & 74 & Instituto Claro \\
\hline 28 & Fundação Clemente Mariani & 75 & Instituto Coca-Cola Brasil \\
\hline 29 & Fundação CSN & 76 & Instituto Consulado da Mulher \\
\hline 30 & Fundação Cultural Oboé & 77 & Instituto Criança é Vida \\
\hline 31 & Fundação Demócrito Rocha & 78 & Instituto de Cidadania Empresarial \\
\hline 32 & Fundação Educar Dpaschoal & 79 & Instituto Desiderata \\
\hline 33 & Fundação Ford & 80 & Instituto Ecofuturo \\
\hline 34 & Fundação Iochpe & 81 & Instituto Elektro \\
\hline 35 & Fundação Itaú Social & 82 & Instituto Embraer de Educação e Pesquisa \\
\hline 36 & Fundação José Silveira & 83 & Instituto Estre \\
\hline 37 & Fundação Lemann & 84 & Instituto Eurofarma \\
\hline 38 & Fundação Maurício Sirotsky Sobrinho & 85 & Instituto Hedging-Griffo \\
\hline 39 & Fundação Nestlé Brasil & 86 & Instituto Holcim \\
\hline 40 & Fundação o Boticário de Proteção à Natureza & 87 & Instituto HSBC Solidariedade \\
\hline 41 & Fundação Odebrecht & 88 & Instituto Lina Galvani \\
\hline 42 & Fundação Orsa & 89 & Instituto Marquês de Salamanca \\
\hline 43 & Fundação Otacílio Coser & 90 & Instituto Medial Saúde \\
\hline 44 & Fundação Ponto Frio Alfredo João Monteverde & 91 & Instituto Nextel \\
\hline 45 & Fundação Projeto Pescar & 92 & Instituto O Boticário \\
\hline 46 & Fundação Roberto Marinho & 93 & Instituto Pão de Açúcar \\
\hline 47 & Fundação Romi & 94 & Instituto Paulo Montenegro \\
\hline
\end{tabular}




\begin{tabular}{|c|c|c|c|}
\hline 95 & Instituto Profarma & 115 & Ismart \\
\hline 96 & Instituto Razão Social & 116 & Itaú Cultural \\
\hline 97 & Instituto Ressoar & 117 & Klabin \\
\hline 98 & Instituto Robert Bosch & 118 & Lojas Renner \\
\hline 99 & Instituto Rogério Steinberg & 119 & Microsoft Informática \\
\hline 100 & Instituto Ronald McDonald & 120 & Natura \\
\hline 101 & Instituto Sabin & 121 & NET \\
\hline 102 & Instituto Sadia de Sustentabilidade & 122 & Oi Futuro \\
\hline 103 & Instituto Sangari & 123 & Petrobras \\
\hline 104 & Instituto Social Sotreq & 124 & Philips do Brasil \\
\hline 105 & Instituto Société Générale & 125 & Pinheiro Neto Advogados \\
\hline 106 & Instituto Socioambiental Invepar & 126 & Politec \\
\hline 107 & Instituto Souza Cruz & 127 & Promon \\
\hline 108 & Instituto Synthesis & 128 & Santander \\
\hline 109 & Instituto Unibanco & 129 & Serasa Experian \\
\hline 110 & Instituto Vivo & 130 & TIM Brasil \\
\hline 111 & Instituto Vonpar & 131 & TNT \\
\hline 112 & Instituto Votorantim & 132 & United Way Brasil \\
\hline 113 & Instituto Wal-Mart & 133 & Xerox do Brasil \\
\hline 114 & Intel Semicondutores do Brasil & & \\
\hline
\end{tabular}

